of certain service sectors as it remained partial (paras 81, 86, and 95-7). In Job Centre, 1997 the Court exclusively applied competition law, which was violated by a refusal to grant permission to open a job recruitment agency in Italy on the ground that this activity was reserved to public agencies. Given that violation, the Court did not continue to assess the case under the freedom of services (para. 39). In Romanelli, 1999 the Court interpreted the term 'other repayable funds' in article 3 Directive 89/646 on banking. In Commission v. Luxembourg, 1999 the Court confirmed that Luxembourg had failed to transpose in time Directive 93/22 on investment services in the securities field.

\title{
V The 2000s
}

The first decade of the millennium was by far the most fruitful of the history of the Court. The Court handed down about 500 judgments in the free movement of persons and services. The free movement of workers and citizens contributed more than 150 judgments. The coordination of social security remained rather stable with a little more than 80 judgments. The exponential growth of the caselaw was most visible in the free movement of services and establishment which together accounted for some 240 judgments.

\section{Workers and citizens}

\section{Worker}

In the first decade of the millennium, the Court added little to the term 'worker'. Fabmi and Amado, 2001 clarified that a migrant worker who had definitely ceased work and then returned to her home state could not lawfully rely on article 48 Treaty and article 7 Regulation 1612/68 to claim a benefit for her children in the state where she had worked (paras 41-51). In Ninni-Orasche, 2003 the Court mainly elaborated that objective criteria and the circumstances were decisive in determining whether a person was a 'worker' (para. 27). Thus, were irrelevant the conduct of the person before and after having begun to seek work (para. 28) or the short duration of the work in relation to the entire residence period (para. 30). The Court also generally disqualified the argument that a person had possibly obtained the position of a 'worker' abusively as a means to benefit from the advantages linked to that status (para. 31). In Collins, 2004 the Court ruled that a person was not to be regarded as a 'worker' by reason of him having last worked in a member state 17 years before (para. 28). The Court also reiterated the distinction between persons who had worked in a member state and then sought employment there, i. e. 'workers', and those who just came to a member state to search for employment, i. e. job seekers (paras 30-32). 


\section{Advantages}

The Court consolidated its case-law on article 7(2) Regulation 1612/68 during the first decade of the 2000s. (As to the case-law relating to tax advantages, see below.) The Kaba, 2000-judgment in essence rubberstamped the approach of the United Kingdom which distinguished between persons who were 'present and settled' in the United Kingdom and those who were not. Essentially, as nationals of other member states were capable of becoming 'present and settled' as well, a problem under article 7(2) Regulation 1612/68 did not arise. The problem was again referred to the Court in Kaba II, 2003, apparently for lack of clarity in the first decision, but the Court simply stuck to its ruling in Kaba, 2000.

In Ferlini, 2000 the Court held that a social advantage within the meaning of article 7(2) Regulation 1612/68 was not involved when the fees for maternity care payable by a person not affiliated to the sickness insurance scheme of a member state exceeded by more than 70 per cent those payable by a person affiliated to that scheme. Such a person who was not affiliated to the scheme did not seek a 'social advantage' with the reimbursement of the maternity expenses, but the application of the same scale of fees as that applicable to persons affiliated to the scheme (para. 44). Given that the scale of higher fees had been imposed unilaterally by hospitals in Ferlini, 2000 (para. 49), the distinction was caught and precluded as indirect discrimination by the general principle of non-discrimination in article 6 Treaty rather than article 48 Treaty.

Leclere, 2001 reiterated that a worker was allowed to claim certain rights even after the employment relationship had ended. However, a worker who ceased work because of invalidity and then received an invalidity pension was not simply to be likened to a worker entitled to benefits under article 7(2) Regulation 1612/68. Such a person only had a claim to such benefits under that article as were linked to her or his former employment. New benefits, such as a benefit on account of a child born after the employment had ended, could, in contrast, not be claimed lawfully (paras 59-60). In Commission v. Luxembourg (minimum income), 2002 Luxembourg conceded the violation of article 7(2) Regulation 1612/68 that resulted from the requirement to have completed a residence period of five years in Luxembourg during the last 20 years to be eligible for the minimum income guaranteed in Luxembourg.

Hartmann, 2007 concerned a residence requirement for a child-raising allowance in Germany. The Court ruled that such a benefit constituted a 'social advantage' for a migrant worker when his spouse claimed the benefit, because it allowed a member of the family of a migrant worker to devote him- or herself to raising the child. This benefitted the migrant worker's family as a whole, regardless of who actually claimed the benefit (para. 26). The Court then struck down the residence requirement largely on the specifics of the case, because the link to the society of Germany - as such a justified requirement for a child-raising benefit - was not only given when a person was resident in Germany, but also when a person contributed significantly to Germany's labour market (paras 34-7). The 
'significant contribution to the national labour market' was thrown into sharp relief on the very same day Hartmann, 2007 had been handed down in Geven, 2007. The Court essentially held in Geven, 2007 that work of 4 to 13 hours per week could lawfully be regarded as minor employment, i. e. an insignificant contribution to the national labour market. As a consequence, a person who was in minor employment could, although still having the status of migrant worker, lawfully be refused the child-raising allowance for lack of a link to the society of Germany.

In Hendrix, 2007 the Court dealt with a benefit made available in the Netherlands to young disabled adults who were unable to gain as much through their work as workers who were not disabled. Article 10a Regulation 1408/71 validly exempted that benefit from exportability (see below). However, the Court continued to examine article 7(2) Regulation 1612/68. The restriction of free movement resulting from the residence requirement, however, was justified by the close link of the benefit to the socio-economic environment (para. 55). Moreover, a hardship clause in Dutch law allowed for the necessary flexibility in cases where it would be disproportionate to refuse the benefit. That was the case of Mr Hendrix who had moved abroad, but maintained close ties to the Netherlands' employment market (para. 57).

In Commission v. Germany (savings-pension bonus), 2009, the Court, finally, categorized the bonus Germany awarded in case of contributions to a complementary savings-pension scheme as a social advantage, although the bonus had the form of an additional tax deduction (paras 41-3 and 49). Limiting this bonus to persons liable to full taxation in Germany affected mostly persons who pursued work across the borders and was thus, in the absence of proper justification, precluded. Those workers were sufficiently closely linked to the German society to take advantage of the benefit, since only those could subscribe to a savings-pension scheme who were affiliated to the mandatory statutory pension scheme in Germany (para. 60). Moreover, to require reimbursement of the bonus when full tax liability in Germany ended was equally precluded for having a deterrent effect on those workers wishing to leave Germany. The ruling handed down was also valid under Union citizenship for economically non-active citizens (para. 115).

\section{Family members}

The Court dealt with the family of migrant workers in a number of judgments. MRAX, 2002 concerned the position of spouses of nationals of the member states who were third country nationals. The Court elaborated that the member states could lawfully require such persons to produce an identity card or a passport as well as proof of their marriage to a national of a member state upon entering their territory. Basically, an entry visa could be required, too. However, only proportionate sanctions were to be taken when a person had entered a country or had remained there without having observed the formalities required. In particular, it was disproportionate to send back a third country national 
spouse who was able to provide the necessary evidence (para. 62). The Court followed up on MRAX, 2002 in Commission v. Spain (visa prior to entry), 2005 to hold unlawful Spain's requirement that third country nationals who were members of a migrant worker's family first obtained a visa at the consulate of Spain where they last were resident (para. 38).

Baumbast, 2002 also dealt with some aspects concerning family members. According to the Court, the children of a migrant worker who had resided with the worker while he had worked in the host state could invoke a right of residence and access to education pursuant to article 12 Regulation 1612/68 even after the migrant worker had ceased work in the host state (para. 55). All the children of the family of the migrant could benefit from these rights, including the descendants of just one of the spouses (para. 57). The nationality of the children was irrelevant (para. 56) and so was the fact that the migrant worker and the spouse had divorced in the meantime (para. 60-61). Moreover, the right of the children under article 12 Regulation 1612/68 also conferred a right of residence to their parent as the primary carer (para. 71 ).

In Givane, 2003 the Court decided that the two year-period of continuous residence pursuant to article 3(2) Regulation 1251/70 had to precede immediately the death of the migrant worker to give rise to the right of the late worker's family to remain in the host state (para. 50). Akrich, 2003 established that a third country national who was the spouse of a national of a member state could only lawfully rely on the rights of spouses pursuant to Regulation 1612/68, in particular the right to family reunification with the migrant worker, if the third country national spouse had already had lawful residence in a member state (para. 50). In other words, a third country national who was married to a national of a member state did not have a claim under Community law allowing her or him to come to the territory of the Community from a third state. The member states alone had the power to regulate such direct family reunification. The Court, moreover, held that a marriage of convenience could possibly amount to abuse of rights (para. 57).

In Mattern and Cikotic, 2006 the Court evoked Gül, 1986 to reason that the rights of third country nationals under article 11 Regulation 1612/68 were linked to the migrant worker. According to Mattern and Cikotic, 2006 a member of the family of a migrant worker was therefore only allowed to rely on article 11 Regulation 1612/68 in the member state where the migrant worker was employed. When a Luxembourg national worked and resided in Belgium, her third country national spouse could therefore not rely on Community law in order to work in Luxembourg (para. 27).

\section{Family members and Union citizenship}

The advent of Union citizenship gave the case-law regarding family members a new turn. The Court in Baumbast, 2002, after having answered the first questions on the basis of the freedom of workers, established the direct effect of the right of residence of Union citizens pursuant to article 18 Treaty (para. 84). The 
only conditions were that a Union citizen was insured against sickness and had sufficient resources so as to not to become an unreasonable burden on the public finances of the host state (para. 90). Those criteria were subject to a proportionality assessment (para. 91). In Zhu and Chen, 2004 the Court added that the interpretation given in Baumbast, 2002 was also valid for minors (para. 20). It did not matter where their resources came from (para. 33). Moreover, in extension of Baumbast, 2002 (para. 71) the right of residence of minor children as Union citizens also conferred a right on their parents to reside with them, despite article 1(2)(b) Directive 90/364 which covered only dependent relatives in the ascending line (para. 45).

Jia, 2007 was not necessarily a citizenship case. Rather, it was handed down on the basis of the freedom of establishment of self-employed persons. However, its main aspect concerned the judgment in Akrich, 2003. The Court emphasised the element of abuse that characterized Akrich, 2003 to find that Community law did not require a member state to insist on prior lawful residence of third country nationals in another member state, but rather left each member state the option to insist on such residence. Furthermore, the Court held that 'dependence', i. e. the need for material support, of a member of the family of a migrant worker or a self-employed person had to be assessed in the light of the situation of that family member in his or her home state or the state where he or she had come from (para. 37). In Eind, 2007, in turn, the impact of Union citizenship was apparent. The Court held that when a national had returned to his home state after having exercised his freedom of movement her or his dependent descendant could still reside with her or him, even though the returning national was not economically active in any way.

In Metock, 2008, the Court then expressly broke with Akrich, 2003 (para. 38 of Metock, 2008). It reduced Akrich, 2003 to the specifics of the facts, namely the element of abuse that was prominent in that case, and held based on a number of considerations - union citizenship and the citizenship Directive 2004/38 among them - that third country nationals who were the spouses of Union citizens could immigrate directly into the territory of the Community from a third country based on Community law. They were no longer required to have lawful residence in a member state before being able to benefit from family reunification based on Community law. Neither did it matter when the family ties were founded. The new approach of Metock, 2008 was promptly confirmed in Sabin, 2008.

\section{Union citizenship, minimex, and students}

In Grzelczyk, 2001 the Court began to revise its case-law on students in the light of Union citizenship. The Court ruled that Belgium's minimum subsistence allowance (minimex), a non-contributory social benefit, could no longer be withheld from students on the grounds that they were not migrant workers. Given that Union citizenship was 'destined to be the fundamental status of nationals of the Member States' (para. 31), a student who had studied for three years in Bel- 
gium while sustaining himself by means of work and then encountered temporary financial difficulties in his final year of studies (para. 44), was allowed to benefit from the Belgian benefit on an equal footing with Belgian nationals, despite the wording to the contrary in Directive 93/96. The Court expanded on Grzelczyk, 2001 in Trojani, 2004, though not with regard to students. The Court held that it was possible for a member state to consider that a Union citizen who had applied for minimex did not have sufficient resources to avoid becoming a burden on the host state (para. 36). However, if a member state granted him a residence permit in spite of his lack of resources, the state would also have had to apply the principle of equal treatment (para. 40). In these circumstances, the member state had to grant the minimex.

In Bidar, 2005 the Court reconsidered students' maintenance grants in the light of Union citizenship. The students case-law previously had been based exclusively on article 12 Treaty. However, the Court in Bidar, 2005 held that the exclusion from Community law of maintenance grants for students who had exercised their freedom to move was no longer warranted. Brown, 1988 and Lair, 1988 were thus not good law any longer (with regard to article 12 Treaty; see Bidar, 2005, para. 42). While the principle of non-discrimination thus had to be applied to maintenance grants, member states could lawfully require that students demonstrated a 'certain degree of integration' and thus a 'genuine link with the society' of the host state (paras 57 and 62, respectively) so as not to become an unreasonable burden on the finances of the host state. That link need not necessarily have been evidenced by employment in the host state (para. 58). A period of residence of certain duration, such as three years, would suffice (paras 59 and 61). A person having received a substantial part of secondary education in the host state could also possibly have established a 'genuine link' to the host state's society (para. 62). In a similar vein, the Court struck down the German conditions to be fulfilled to obtain an education and training grant to study abroad in Morgan, 2007. Germany had required resident students to have pursued studies for at least a year in Germany and to continue the same studies in another member state to be eligible for a grant. However, the Court found that the genuine link required by Bidar, 2005 was already established when a student had been raised and had completed schooling in Germany (para. 45). The conditions Germany imposed did therefore not cover all the situations in which the genuine link to the German society existed (para. 46). They were thus not necessary to ensure that a student did not become an unreasonable burden for Germany. The Court also rejected a number of other grounds - such as ensuring that students pursued studies in as brief time as possible, that they had chosen the right studies for them, or that grants were not duplicated. Those grounds were inappropriate or unnecessary to justify the obstacle Germany had created to the free movement of Union citizens. In Förster, 2008, in some contrast, the Court upheld the requirement of five years of residence in the Netherlands for students to be eligible for maintenance grants. That condition satisfied, according to the Court, the 'genuine link'-requirement of Bidar, 2005 (Förster, 
2008, paras 52-5). The citizenship Directive 2004/38, which had not been applicable at the time of Förster, 2008, in essence relied on the very same condition (para. 55).

\section{Education without Union citizenship}

Judgments were also handed down in the 2000s that merely developed the caselaw on education without that Union citizenship had much impact. Before Bidar, 2005, Ninni-Orasche, 2003 had clarified the requirement that unemployment had to be involuntary for a worker seeking re-training after having lost employment in order to justify application of article 48 Treaty and article 7(2) Regulation 1612/68 to lay claim to student maintenance assistance. (See Lair, 1988 for the requirement of continuity.) The Court explained that even when temporary employment ended the worker could be involuntarily unemployed depending on the circumstances (para. 42). Such circumstances could exist in a practice that was usual for this type of employment, in the chances of finding long-term employment, and in the possibility to renew a contract (para. 44). The Court also held in Commission v. Belgium (CESS), 2004 that Belgium could not lawfully require prospective students who did not have a Belgian certificat d'enseignement supérieur, but had passed secondary education in another member state, to pass an aptitude test to gain access to higher education in Belgium. In Commission v. Austria (university), 2005 an even less restrictive requirement in Austria was invalidated by the Court, too. Austria had required prospective students to show that they had access in the state where they had obtained their secondary education to the studies they wished to pursue in Austria. Austria had failed to show that, without the requirement, the existence of the Austrian university system as such or its homogeneity would have been jeopardised (para. 66). Non-discriminatory entry examinations or minimum grades for access to certain studies would have been in accordance with article 12 Treaty though (para. 61).

\section{Tideover allowance and Union citizenship}

The impact of Union citizenship on the tideover allowance Belgium granted to jobseekers who looked for the first job after their studies was at issue in D'Hoop, 2002. The Court ruled that in view of Union citizenship the allowance could no longer be reserved to students who had passed secondary education in Belgium. A real link of the applicant to the geographic employment market could lawfully be required, but the criterion applied by Belgium was too 'general and exclusive' (paras 38-9). The Court also held that Union citizens were entitled to invoke Union citizenship against the member state of which they were nationals, after having made use of the freedom of movement (para. 30). In Ioannidis, 2005 the Court further developed the tideover allowance. The allowance was not to be refused to a Union citizen, either, on the sole ground that the parents of the citizen were not migrant workers in the host state. While the parents' work in the host state was possibly indicative of the 'real link' to the geographic 
employment market, it could not be excluded, according to the Court, that a Union citizen had established such a real link on other grounds (para. 33).

\section{Job seekers and Union citizenship}

Building on D'Hoop, 2002, the Court in Collins, 2004 further elaborated on the benefits of job seekers in the light of Union citizenship. The Court held that, in view of Union citizenship, the job seeker's allowance provided by the law of the United Kingdom could no longer be excluded from the scope of article 48(2) Treaty (para. 63). A genuine link of the job seeker to the employment market could, however, be required lawfully. The allowance could be subject to the job seeker having effectively and genuinely searched for employment for a certain time (para. 70). Residence as a criterion was apt to ensure that the genuine link to the job market existed, provided that the period of residence required was not excessively long (para. 72). This interpretation of the freedom of workers in the light of Union citizenship was confirmed in Vatsouras, 2009. Given that the legal basis of the claim of job seekers to benefits was still free movement of workers, the Court also held in Vatsouras, 2009 that article 24(2) of the citizenship Directive 2004/38 was valid, for it was susceptible to a reading in accordance with article 39(2) Treaty (paras 44-5).

\section{Genuine link again}

The requirement of a genuine link to the society of the host state was also applied under Union citizenship by the Court in Gottwald, 2009. Austria had required disabled persons, for whom a reduced price for the toll disc necessary to use highways in Austria was available, to be resident in Austria to benefit from the reduced price. The Court ruled that the residence requirement ensured that disabled Union citizens had a connection to the society providing the benefit (para. 36). Decisive elements in that consideration were (i) that the disadvantage, i. e. the higher price for the toll disc, merely affected those who passed through Austria only occasionally, (ii) that a minimum period of residence was not required (para. 37) and (iii) that 'residence' was interpreted by the Austrian authorities so as to include situations where there was a connection of a similar degree as in the case of ordinary residence (paras 38-9).

\section{War victims and Union citizenship}

With Tas-Hagen, 2006 benefits granted to civilian war victims came under the scrutiny of Union citizenship. Yet before Tas-Hagen, 2006, the Court in Baldinger, 2004 rejected the claim of a former Austrian national, who had become a Swedish national before the accession of Austria to the Community, for a benefit provided by Austria for prisoners of war in World War I or II who were Austrian nationals at the time they applied for the benefit. In keeping with Even, 1979 the Court held the benefit to be outside the scope of free movement of workers and, in particular, Regulation 1408/71. The Court did not enter into the argument to the contrary that Advocate General Ruiz-Jarabo Colomer had made 
on the basis of Union citizenship (paras 24-47 of the opinion in Baldinger, 2004). In Tas-Hagen, 2006, however, the Court applied Union citizenship and decided that the Netherlands were not to refuse a civilian war victims benefit merely because one of its own citizens had made use of the freedom as a citizen to move and therefore lived in Spain at the time of the application for the benefit. To require residence at the time of the application had a dissuasive effect on the freedom of Union citizens to move and was too selective as a criterion to establish the link to the Dutch society which the Netherlands legitimately required for such a benefit (para. 39). In the same vein, the Court rejected a requirement of continued residence imposed by Poland for the award of a war victim benefits in Nerkowska, 2008. It would have been less restrictive to require regular visits rather than residence in order to verify that the conditions of the benefit continued to be met (para. 45). For a similar war victim benefit the Court in ZablockaWeyhermüller, 2008 rebuffed Germany's way of reducing the benefit when the beneficiary resided abroad. The aspect that made the reduction disproportionate was that it only applied in the case of residence in certain countries, namely those that had belonged to the Soviet Union or to Yugoslavia but not some member states where the cost of living was equally low (para. 43). Moreover, the monitoring of the beneficiary's situation was necessary to the same extent, no matter which member state was involved (para. 44).

\section{Union citizenship and expulsion}

In Jipa, 2008 the Court examined an order adopted by Romania against one of its own citizens ordering the citizen not to leave Romania for three years, because he had been expelled from France. A national was entitled, the Court stated, to rely on the freedom of movement of Union citizens to leave his country of origin (para. 18). The Court in essence applied under Union citizenship the expulsion case-law developed in the domain of workers (paras 23-4). The order by another member state to leave the country by itself was, according to the Court, not sufficient as justification for a member state to restrict the freedom of movement of one of its own nationals to its own territory. The domestic authorities had to conduct a full examination within the meaning of the expulsion case-law into which the public security considerations of the other member state could be fed (paras 25-6).

\section{Names and Union citizenship}

In Garcia Avello, 2003 the Court relied on Union citizenship to decide that it was contrary to the right to equal treatment of Union citizens for Belgium to refuse to register the dual last name of a national of Spain and Belgium as it was current in Spain. The fact that two countries, namely Spain and Belgium, registered two different names for the same person could bring about a 'serious inconvenience' for that person (para. 36). This inconvenience was not justifiable by the need to avoid the general risk of creating confusion (para. 42). The Court decided in Grunkin, 2008 on similar grounds that the refusal to register in Ger- 
many the double-barrelled surname lawfully conferred to a German national in Denmark violated the free movement of citizens.

\section{Union citizenship and institutional issues}

The Court also addressed institutional issues in the light of Union citizenship. In Kaur, 2001 the Court ruled that the declaration made by the United Kingdom upon accession to the Community, which was later on amended, was relevant to determine who was a Union citizen. Those persons who did not fulfil the conditions in the declaration were not entitled to claim that they lost rights under Community law because of the declaration, as the declaration prevented rights from arising in the first place (para. 25). Issues related to the constituency of the United Kingdom also came up in Spain v. United Kingdom (Gibraltar), 2006. The Court ruled that the member states had the power to determine the franchise and eligibility in elections for the European Parliament, as long as Union citizens from other member states were allowed to participate. In other words, the United Kingdom could lawfully determine who were 'its' citizens that were allowed to participate in the elections to the European Parliament in the United Kingdom. Thus, the United Kingdom validly extended the right to vote in European parliamentary elections in Gibraltar to third country nationals who had close links to the United Kingdom based on historical constitutional traditions. Similarly, the Court decided, on the same day as Spain v. United Kingdom (Gibraltar), 2006 was delivered, in Eman and Sevinger, 2006 that it was up to the Netherlands to determine its constituency for the European Parliament elections. However, the Dutch citizens in Aruba and the Netherlands Antilles, which were Dutch overseas territories, were not to be excluded from such elections, if Dutch citizens in non-member states were generally allowed to participate in them (paras 58 and 60).

\section{Union citizenship and other policies}

In Wolzenburg, 2009, the Court made it plain that provisions implementing framework decisions of the Union had to respect Community law, in particular the rights qua Union citizenship (para. 45). The Netherlands complied with the limits imposed by Union citizenship and non-discrimination when it restricted the cases in which it refused to execute a European arrest warrant seeking the execution of a judgment (which was an option offered by the relevant framework decision) to those warrants targeting either Dutch nationals or Union citizens who had resided in the Netherlands for five years. The main reason was that only persons in those two categories had a connection to the Dutch society that was sufficient to outlast the prison sentence. Only for them it was therefore reasonable to serve the sentence in the Netherlands instead of being extradited (see paras 67-73). However, the Netherlands were not to require a permit of indefinite duration as evidence of the permanent residence, because the right to permanent residence in article 16(1) citizenship Directive 2004/38 did not depend on administrative documents (paras 49-52). 
As to the Schengen system, the Court held in Commission v. Spain (Schengen alert), 2006 that Schengen law had to respect the rights individuals derived from Community law. When an alert concerning a third country national married to a Union citizen was entered into the Schengen information system the reasons why the Schengen alert had been entered had to be available rapidly to the authorities which were in a position to refuse entry into a state belonging to the Schengen area, because such third country nationals benefitted from the enhanced protection against public policy and security measures in Community law (para. 58).

In a similar vein, the Court examined Germany's register of foreigners in the light of the data protection Directive 95/46 and Union citizenship in Huber, 2008. The Court found that a separate register for Union citizens residing in Germany which contained the data Union citizens had to provide under the relevant Community legislation was, under certain conditions, in accordance with the rights of Union citizens to free movement, given the need to control residence (paras 58-62). However, registering the crimes committed by Union citizens separately, i. e. besides and in addition to the general register of crimes, was not justified to fight crimes, for with regard to the fight against crimes the situation of Union citizens was not different from that of German nationals (paras 77-9).

\section{Taxation}

Taxes occupied the Court repeatedly during the first decade of the millennium under the free movement of workers as well as Union citizenship. Zurstrassen, 2000 expanded the Schumacker, 1995-case law. The Court ruled that a member state could not lawfully refuse the joint tax assessment of spouses, merely because one spouse was resident abroad, if the couple gained almost all of their income in that member state. The reason was, as in Schumacker, 1995, that that member state was the only state that could possibly take into account the personal and family circumstances of the taxpayer (para. 23). In De Groot, 2002 the Netherlands refused to take into account all the personal and family circumstances of a resident taxpayer. The problem was that $\mathrm{Mr}$ de Groot had also earned income in several other member states. The Netherlands refused to factor in fully the maintenance payments $\mathrm{Mr}$ de Groot made by reason of his divorce, but - unlike for residents who earned all their income in the Netherlands - took into account only the amount proportionate to the income in the Netherlands. Consequently, a part of the payments was not taken into account for income tax purposes anywhere. The Court ruled that a situation in which personal and family circumstances were taken into account for income tax purposes in no member state at all was contrary to free movement of workers (paras 101-2). The Netherlands thus had to either adjust their tax system unilaterally or amend their double taxation conventions with other member states accordingly (para. 99).

In Wallentin, 2004 the Court again applied Schumacker, 1995 to find that the refusal to apply the allowance that was tax free, i. e. the amount of income not subject to income tax, to a migrant worker, because he had stayed less than six months in the host state, violated the free movement of workers when the work- 
er had not gained any taxable income in other member states. The allowance constituted a 'personal circumstance' within the meaning of Schumacker, 1995, as its aim was to alleviate the tax burden of persons with low income. Turpeinen, 2006 was again a tax case decided on the basis of Schumacker, 1995. However, in this case the Court per analogiam applied Schumacker, 1995 to Union citizenship. The case concerned a similar constellation as Pusa, 2004, namely a Finnish national who had moved to Spain after retirement (see Pusa, 2004 below). Finland, however, applied a flat rate withholding tax to pensions paid in Finland in case of non-resident retired taxpayers, whereas a progressive tax rate applied to resident pensioners. In the case of Ms Turpeinen this led to a higher tax burden than if she had maintained her residence in Finland. With Finland being the only state where she received a pension, the Court found that Schumacker, 1995 applied by analogy (para. 29). The higher tax burden therefore violated the free movement of citizens and equal treatment (paras 31 and 33).

Based on the free movement of workers the Court also invalidated an approach Belgium used to tax persons who were simultaneously self-employed in Belgium and employed in Germany in Mertens, 2002. The Court in this case relied heavily on AMID, 2000, an establishment case that concerned company taxation, to order that Belgium for tax purposes was not to set off losses incurred because of a self-employed activity in Belgium against income gained by reason of work in Germany when determining the losses to be carried over to the following tax year. The crux was that when a person who was self-employed in Belgium was simultaneously employed in Belgium rather than Germany the losses were deductible from the taxable income gained from employment in Belgium (para. 28), whereas with simultaneous employment in Germany the losses made in Belgium were not deductible from income. As a result, the losses incurred in Belgium were not deductible anywhere (para. 23), which hindered free movement of workers (para. 33). The Court decided so based on the facts that (i) the two cases, i. e. employment and self-employment both in Belgium v. employment in Belgium and self-employment in Germany, were not comparable and Belgium was therefore precluded from applying the same approach in both cases (para. 31); (ii) Belgium's approach was unilateral (para. 36); (iii) the losses incurred in Belgium as a result of the self-employed activity were, in keeping with the double taxation convention, not taken into account in Germany in the taxation of the income earned by reason of the employment in Germany (para. 31).

\section{Taxes and houses}

The Court addressed losses for tax purposes in the light of free movement of workers in Ritter-Coulais, 2006 as well. In this case, Germany had applied a difference in treatment depending on whether a loss of income by reason of an owner living in his own house arose from either the house being situated in Germany - in which case the loss of income was taken into account to determine the applicable income tax rate - or the house being situated in another member state 
- in which case the loss of income was left out of account, save to offset positive income from the same source. However, the positive income from real estate was always factored in irrespective of where the real estate was situated. The Court found that difference in treatment to be an unjustified restriction of the freedom of workers (para. 37-8). The Court then came back to Ritter-Coulais, 2006 under slightly different circumstances in Lakebrink, 2007. Luxembourg legislation never took into account the yields of real estate situated abroad for the purpose of determining the tax rate; in other words, it was not just negative income that was disregarded as in Ritter-Coulais, 2006, but also positive income from real estate. Moreover, whether the owner used the real property concerned to live there himself was irrelevant. In short, Luxembourg treated residents differently than non-residents in that, for residents, positive and negative income from real estate was factored in to determine the applicable tax rate, while for non-residents neither positive nor negative income was factored in (para. 18). The Court ruled that the advantages such legislation created for migrant workers when they declared positive income from real estate abroad, did not offset the disadvantages in cases where negative income having arisen from such real estate was left out of account (paras 22-24). Moreover, the Court ruled, falling back on Schumacker, 1995, that when a non-resident taxpayer gained almost all of his income in Luxembourg the personal and family circumstances had to be taken into account for tax purposes. That included all the factors affecting the taxpayer's ability to pay tax (para. 34), including negative income originating in real estate situated abroad. Thus, the Luxembourg legislation constituted discrimination contrary to article 39 Treaty (para. 35). In Renneberg, 2008 the Court again came back to Ritter-Coulais, 2006 and Lakebrink, 2007 read in the light of Schumacker, 1995. In Renneberg, 2008, the Netherlands refused to take into account negative rental income originating in an owner-occupied dwelling situated in Belgium for the purpose of determining the income tax base. The person concerned earned all of his work-related income in the Netherlands. According to the Court, the Netherlands had to apply Schumacker, 1995 (paras 64 and 71), even though the relevant double taxation convention allocated to Belgium the power to tax income from real estate situated in Belgium. If the Netherlands took negative income from real property situated in Belgium into account for residents, they had to do so for non-residents as well (paras 56-8).

\section{Cohesion of the tax system}

In Commission v. Denmark (insurance taxation), 2007 the Court addressed a similar constellation as in Bachmann, 1992 and Commission v. Belgium (insurance taxation), 1992. Denmark required pension or life insurance contributions to have been made under a pension scheme taken out with an insurer established in Denmark to be income tax deductible. The Court found a restriction of the freedom of workers and establishment, in particular of those persons coming to Denmark and having previously taken out insurance abroad which they intended to maintain, but also of services because of either the requirement of being estab- 
lished in Denmark or the deterrence for receiving services abroad (paras 39-44). Those restrictions were not justified. Effective supervision was made possible by Directive $77 / 799$ on mutual assistance and by evidence to be provided by the taxpayer (paras 52-6). A general presumption of tax avoidance was not to be applied (para. 57). The cohesion of the Danish tax system was only in peril when a person moved abroad after having deducted the contributions from income but before receiving the benefit that would be taxable as income in Denmark. The Court held that that possibility alone was not sufficient to establish a direct link which could justify a general requirement of establishment in Denmark for insurers (paras 72-4).

\section{Taxation of employees of the Communities}

The Court dealt with the special tax situation of workers employed by the European Communities in Schilling, 2003. In that specific context, the Court held that it was contrary to the freedom of workers for the 'home' state, which was competent to tax all income other than the salary of persons employed by the Community, to refuse the deduction from income originating in real estate for the cost incurred by reason of employment of a household help - cost that were normally deductible from income - on the sole ground that the social security contributions for the help were not paid to the home state's social security scheme, but to another member state's social security scheme.

\section{Taxes and Union citizenship}

In Pusa, 2004 taxes were examined in the light of Union citizenship. A pensioner had moved from Finland to Spain where he paid income tax on his retirement pension received in Finland. However, the Finnish authorities calculated the attachable part of the pension without taking into account the income tax payable in Spain, while they would have deducted the income tax prepayment normally due in Finland. The Court found that approach acceptable under Union citizenship given that it allowed the debtor to shield part of his income from the creditor's right of recovery, provided, however, that the tax had not yet been due at the time the creditor claimed a part of the pension (paras 26-7). Moreover, a provisional tax assessment was available in the debt enforcement procedure in Finland for income tax not yet payable (paras 40-2). However, in this assessment any discretion of the authorities had to be excluded for it to be in accordance with Union citizenship (para. 45).

In Schempp, 2005 the Court applied Union citizenship and non-discrimination. It did not find a violation in that Germany rejected the deductibility of maintenance payments made to a former wife resident in Austria, although such payments would have been deductible from income had the recipient lived in Germany. Germany could lawfully reject the deductibility when payments were made to a recipient in another member state which did not subject these payments to income tax in the hands of the recipient (paras 30-5). The Court also relied on the Lindfors, 2004-ruling (see below) on the absence of a guarantee of 
tax neutrality when Union citizens exercised their freedom to move (para. 45-6). In Rüffler, 2009 the Court, in turn, based on Union citizenship invalidated the way Poland taxed the income of a retired pensioner resident in Poland. The pension was paid in Germany and compulsory sickness insurance contributions were deducted at source in accordance with Regulation 1408/71. However, Poland had calculated the income tax due on the basis of the gross pension, i. e. before the deduction of the contributions in Germany, although the contributions had not been taken into account for income tax purposes in Germany in any way, while Poland would have computed on a net basis had the pension been paid in Poland. The Court found a difference in treatment (paras 67-8) which was not justified given that Germany compensated Poland for the benefits in kind provided in actual fact to pensioners residing in Poland in keeping with Regulation $1408 / 71$.

\section{Taxes on cars}

Taxes other than income tax were also scrutinized by the Court in the light of the free movement of workers and citizenship. In Weigel, 2004 the Court did not find a violation in the tax due in Austria when a used car was registered. $\mathrm{Mr}$ Weigel had claimed that his freedom to move as a worker had been violated, because he had been forced to re-register his car and pay the tax due in Austria, after he had moved there to work. However, the Court found that the Treaty did not contain a guarantee of tax neutrality of movements of migrant workers. The migrant worker was not placed at a disadvantage compared to those who had already been subject to the legislation of the host state (para. 55). In Lindfors, 2004 the very same reasoning as in Weigel, 2004 was applied under Union citizenship to a car tax levied by Finland (paras 34-5). In Alevizos, 2007, Weigel, 2004 and Lindfors, 2004 were confirmed. However, the Court further elaborated in Alevizos, 2007 on the aspect that the taxation of the vehicle imported had to avoid any disadvantages for Union citizens. The level of the tax on the vehicle imported had to take into account the vehicle's depreciation (para. 78).

\section{Taxes and real estate}

In Commission v. Portugal (capital gains deduction), 2006 the Court applied the freedom of workers, establishment, and citizens to strike down an exemption from the tax on capital gains realised upon selling real estate which had served as a home to the owner or her family. The law of Portugal had limited that exemption to the situation where the proceeds of the sale were used to acquire another home in Portugal. The Court held that restriction to be unjustified. This judgment was confirmed in Commission v. Sweden (tax deferral), 2007 for the deferral of the taxation of capital gains on real estate situated in Sweden. In a similar vein, the Court in Commission v. Germany (bousing subsidy), 2008 invalidated the German housing subsidy in the light of the free movement of persons and Union citizenship in so far as it was only granted when persons subject to unlimited income taxation in Germany had acquired real estate for their own 
occupation that (the real estate) was situated in Germany. The Court found that the aim the subsidy pursued, namely allowing taxpayers to acquire their own dwelling, was equally attained when the real property acquired was situated abroad (para. 28). This was confirmed in Commission v. Germany (savings-pension bonus), 2009 for the use of certain subsidized capital to acquire a dwelling in Germany (para. 82).

\section{Interim assistance and taxation}

In Merida, 2004, finally, the way income tax was dealt with had an influence on another benefit. The German interim assistance for unemployed persons had been calculated on a basis of assessment as if the income gained by a worker in Germany had been subject to income tax in Germany, i. e. in the calculation of the benefit the German tax was notionally deducted from the wage the dismissed worker had gained. In the case at hand, this resulted in a lower benefit than if the income tax paid in actual fact in France, which was lower than the income tax in Germany, had been taken as a basis. According to the Court, this approach violated the free movement of workers, more specifically, article 7(4) Regulation 1612/68), for having an unfavourable effect on the migrant worker concerned (para. 28).

\section{Derogations}

In the first decade of the millennium, the Court also dealt with the derogations from the free movement of workers. In the year 2000, the Court mainly re-applied established case-law regarding the public service exception pursuant to article 48(4) Treaty in Österreichischer Gewerkschaftsbund, 2000. The Court ruled that once access to public employment had been granted, non-discrimination applied. Austria, however, failed to live up to that standard when it applied stricter conditions to take into account periods of employment in another member state than those applicable to periods of comparable employment completed in Austria. In the absence of transitional provisions, that also applied to periods of employment completed before accession of a member state to the Community (para. 55). In the twin judgments of 30 September 2003, Marina Mercante, 2003 and Anker, 2003, the Court addressed the reservation of the captaincy and first office on ships flying the flag of a member state to the nationals of that state. The Court ruled that the mere employment by a private person was not sufficient to render the public service exception inapplicable in the case of ship masters and chief mates (Marina Mercante, 2003, para. 43). The exception in principle applied when a person exercised official authority by means of certain notarial and police powers (Marina Mercante, 2003, para. 42). However, the exception only applied when those powers were exercised on a regular basis and were not a very minor part of the activities concerned (Marina Mercante, 2003, para. 44). The Court had to repeat the ruling in four more infringement proceedings almost five years after Marina Mercante, 2003 and Anker, 2003 before the message had finally sunk in (Commission v. France (ship officers), 2008; Commis- 
sion v. Greece (ship officers), 2009; Commission v. Italy (ship officers), 2008; Commission v. Spain (ship officers), 2008). In Alevizos, 2007 the Court, in addition, made it clear that even with an army officer whose employment squarely came within the public service exception taxation which had no link to him being an officer, such as taxation at the occasion of a transfer of residence to another member state, could be challenged under the free movement of workers (para. 71).

In a series of infringement cases - Commission v. Finland (military equipment), 2009; Commission v. Germany (military equipment), 2009; Commission v. Sweden (military equipment), 2009; Commission v. Italy (military equipment), 2009; Commission v. Italy (dual use equipment), 2009; Commission v. Greece (military equipment), 2009; Commission v. Denmark (military equipment), 2009 - that concerned the member states' duty to contribute to the Community's own resources, and more specifically the duty to communicate imports of military equipment to the Commission giving rise (the imports) to a duty to contribute, the Court elaborated the public safety derogation under all the market freedoms, including the freedom of workers. The Court in all those judgments held that the public safety derogations to the market freedoms were not to be interpreted to the effect that a general exception was inherent in Community law which allowed to remove whole domains related to public security from the scope of Community law (see e. g. Commission v. Finland (military equipment), 2009, paras 45-6).

The Court applied the public policy derogation as well, namely in Olazabal, 2002. Rutili, 1975 was put into perspective as the Court held that the freedom of movement of a Spanish national could lawfully be restricted to parts of the territory of France when the migrant worker concerned could as well have been expelled from France on grounds of public order (para. 41). In Orfanopoulos, 2004, the Court held that the public policy derogation had to be applied particularly restrictively in the light of Union citizenship (para. 65). Any automatism and presumption were excluded when it came to the expulsion of a migrant worker on public policy grounds (paras 70 and 93). The threat to public policy had to be reviewed, moreover, whenever a lengthy period had passed after the expulsion decision was adopted (para. 81). The Court also elaborated the proportionality analysis the national court had to undertake into which the human rights of the person concerned had to be fed (paras 97-9). Moreover, the Court clarified the procedural safeguards applicable in case of expulsion. Orfanopoulos, 2004 was by and large confirmed in Commission v. Netherlands (automatic expulsion), 2007. In addition, the Court made it plain that all Union citizens, even those who did not reside lawfully in a member state, benefitted from the safeguards of Community law in case of expulsion (para. 35). The case Commission v. Germany (expulsion), 2006 also concerned derogations from free movement. The Commission had challenged Germany's implementation of the Community rules on expulsion. However, the Court mainly found that the Commission had failed to meet the standard of evidence required to establish an 'admin- 
istrative practice' contrary to Community law. The Commission had merely put forward a number of cases spanning almost a decade in which the expulsion standards had allegedly been violated.

\section{Sufficient resources}

In a similar vein as in the expulsion case-law the Court dealt with the issue of a Union citizen not having sufficient resources to avoid becoming a burden to the host state. In Commission v. Belgium (own resources), 2006 the Court held that a member state could not lawfully require a Union citizen to have a legal right to the financial resources she used to maintain herself (para. 46-7). Thus, an agreement as to assistance concluded before a notary could not be required where a partner supported the Union citizen concerned. Nor could automatic expulsion ensue from a lack of evidence as to the existence of sufficient resources (para. 68). Both measures were found to be disproportionate to ensure protection of the financial interests of a member state. Similarly, the Court rejected in Commission $v$. Netherlands (own means), 2008 the requirement of the Netherlands to have sufficient resources for an entire year to be eligible for a residence permit (para. 29).

\section{Non-discrimination}

The Court also ruled on the basis of non-discrimination of migrant workers in a series of other cases during the first decade of the millennium. In Graf, 2000 the Court judged that a rule according to which an employee forfeited the right to a compensation worth two months of salary when he himself rather than the employer had terminated the employment contract did not violate the migrant worker's access to the internal labour market. The entitlement to compensation was conditioned on a 'future and hypothetical event' (para. 24). The possibility that the employer would have eventually terminated the contract, had not the employee done so, was 'too uncertain and indirect a possibility' for the legislation to constitute an obstacle to market access (para. 25). The rule therefore respected the principle of non-discrimination.

In Lehtonen, 2000 the Court came back to sports, this time basketball. The Court validated the transfer window rule which was recommended by the European basketball federation to the national federations. This rule established that all transfers of players within Europe had to be concluded before the end of February of each year. The rule was justified to ensure the 'regularity of sporting competitions' (para. 53), i. e. that transfers were not made after the regular season was over and the play-offs and relegation games had begun (paras 54-5). However, while it seemed unnecessary to the Court that the transfer window remained open a month longer for transfers of players from outside Europe, the Court left it to the national court to find objective reasons to justify that discrepancy.

In Angonese, 2000, the Court found that the requirement to have a specific language certificate which could only be obtained in a specific region violated 
the free movement of workers. While a language requirement as such did not pose any problem as such, migrant workers had to be allowed to prove language proficiency by other means (paras 44-5). Moreover, the Court held based on the line of authority that had begun with Walrave, 1974 that the principle of nondiscrimination applied as well to regulations adopted by private persons, such as banks in this case (para. 36). The latter ruling was confirmed in Raccanelli, 2008 for private associations, such as the German Max Planck Gesellschaft as an employer.

Commission v. Italy (language assistants), 2001 dealt with Italian language assistants again. This time the Court invalidated the conversion of fixed-term contracts of language assistants into contracts of indeterminate duration, because in doing so the rights acquired previously as language assistants were, in contrast to regular workers, left out of account. This was confirmed in Delay, 2008, provided, however, that there was continuity between the duties under the first and the second contract.

Burbaud, 2003 concerned France's recruitment system for civil servants in hospitals which combined an initial selection with ensuing training and provisional civil servanthood. The Court ruled that migrant workers who had passed similar training in another member state, if it had to be recognized under the Community rules (see below), had to be offered a simplified option to access employment as civil servants in hospitals - to be more specific, an option that exempted them from undertaking again the training they had already passed in another member state, but still ensured the legitimate selection of the candidates most suitable for employment (para. 109).

In Köbler, 2003 the Court held that a special salary supplement awarded after 15 years of employment could not lawfully be reserved to those professors who had performed their duties exclusively at Austrian universities. The reward for the loyalty of an employee embodied by the supplement did not justify the obstacle created to free movement of workers, since it applied to the duties performed at any Austrian university, while universities in Austria in effect competed amongst themselves for the most able professors in a similar way as with foreign universities (para. 84).

With Commission v. Italy (teaching experience), 2005 the Court held in the light of Scholz, 1994 that Italy could not lawfully attribute a different value to a teacher's experience acquired abroad than to that acquired in Italy (para. 21). This was again confirmed for the impact of work experience in public service abroad on the salary paid in Commission v. Spain (work experience), 2006. Commission v. Italy (work experience), 2006 reiterated this ruling regarding professional experience and seniority acquired in public service abroad and added that it was immaterial in this regard whether a member state recruited civil servants based on a public competition or not (para. 18) and whether a civil servant worked under a contract or not (para. 19). 


\section{Car registration}

In Van Lent, 2003 it was prohibited in Belgium to use a car registered in another member state which an employer established there had leased for his employee residing in Belgium. In fact, such a vehicle could not be registered in Belgium, neither by the employer nor by the employee. The Court held that the obstacle to the free movement of workers which arose by reason of the fact that a migrant worker residing in Belgium was prevented from benefitting from a leased car provided by his employer established abroad (paras 19-20) was not justified by the need to ensure road safety. This applied even if it had been possible to register such a car in Belgium (para. 25). Car registration was also at issue in Commission v. Denmark (car registration), 2005. Denmark required resident persons who worked for an employer established abroad providing them with a car to obtain an authorization in Denmark to use the car and to pay a tax. The Court, similarly as in Van Lent, 2003 held that the access of workers and employers to the labour market was hindered. That restriction of the free movement of workers would only have been justified, if the car had been used in Denmark on a permanent basis rather than just occasionally (paras 76-8). This applied regardless of whether that use was for business purposes only or also for private purposes. This judgment was confirmed in Commission v. Finland (car registration), 2006.

\section{Further non-discrimination}

In Kranemann, 2005 the Court rejected Germany's limiting the reimbursement of trainee lawyers' travel expenses for training purposes to journeys within Germany. The financial obstacle for trainee lawyers to seek training in another member state was not justifiable by budgetary considerations (paras 29 and 34). Öberg, 2006 was handed down on the same day as Rockler, 2006. Both judgments essentially concerned the same constellation. The Court ruled that Sweden violated the free movement of workers pursuant to article 39 Treaty when it refused to take into account insurance periods a worker had completed with the insurance scheme of the Community for the purpose of determining whether the 240-days period of insurance needed for the award of a parental benefit in Sweden was fulfilled.

Lyyski, 2007 concerned the efforts in Sweden to train a sufficient number of teachers to address an acute lack of teaching personnel. Mr Lyyski had claimed that he intended to fulfil the practical part of an educational course for teachers given in Sweden in a Swedish-speaking school in Finland. Given the urgency of the lack of teachers in Sweden and the temporary nature of the measures, the Court in principle accepted the restriction of the freedom of workers inherent in the Swedish requirement that the practical part be passed at a school in Sweden. But the Court ultimately left the proportionality assessment to the national court, requiring the latter, however, to factor in the need to monitor candidates in their practical training and a potential lack of candidates qualifying for the course (paras 43-4 and 46). 
In ITC, 2007, the Court rejected in light of the free movement of workers Germany's approach to finding employment for unemployed workers. The approach essentially consisted in paying a fixed amount of money for each unemployed person a private recruitment agency managed to place, provided though that the job concerned was subject to contributions to the German social security system. With reference to Clean Car, 1998 the Court found that a private recruitment agency was entitled to rely on the freedom of workers of the person placed, although it acted only as an intermediary between the employer and the employee (paras 24-6). The restriction to employment subject to the German social security system was not justified, though. Germany had failed to bring sufficient evidence that the restriction in the new social policy instrument was necessary to encourage recruitment. Equally it seemed unnecessary to protect the national social security system - in particular the financial balance of the social security system was not at risk of being upset, given that the fee paid was counterbalanced by the unemployment benefits that need not have been paid any longer - or to prevent the loss of qualified labour, if the latter was a ground suitable for justification at all (paras 39-44). In a similar vein, the freedom of recruitment agencies to provide services and of recipients to receive them was unlawfully restricted. The freedom of services was, in particular, restricted when a recruitment agency established in Germany, after having found employment for a worker in another member state, then had to rely on the worker, rather than the state, to pay the fee (paras 57-9). As the freedom of workers and services gave specific expression to Union citizenship, the Court did not deal with the latter (paras 64-5).

In Wood, 2008, the Court turned down France's approach to compensate persons for damage suffered by reason of criminal offences. Union citizens were only entitled to receive compensation, if the relevant act had been committed in France, in contrast to French nationals who were always eligible. The approach was considered directly discriminatory in the case of a Union citizen who had made use of his freedom to come to work and reside in France (para. 15).

\section{Ankara}

In the first decade of the millennium the Court addressed the rights of workers under the Ankara Agreement with Turkey in more than twenty judgments. In Nazli, 2000, the Court held that a worker who came under the third indent of article 6(1) Decision 1/80 belonged to the duly registered labour force despite short absences from the labour market. In Mr Nazli's case the absence lasted 13 months due to detention pending trial. However, the Court added the proviso that the person concerned found employment again after a reasonable period (paras 40 and 42). This applied also when enforcement of the prison sentence had been suspended, because such a measure usually aimed at a person's integration in the host state's society (para. 48). Moreover, the expulsion case-law developed for the internal market equally applied under the Ankara Agreement (para. 56). In Kocak, 2000, however, the Court refused to apply Dafeki, 1997 to the facts at issue. The reason was that Germany had amended its practice as to 
changes of dates of birth since Dafeki, 1997. Of late, the first declaration of the date of birth was consistently relevant, except where a document that had existed before the first declaration had been made proved an earlier date of birth. With all documents regardless of whether they originated in Germany or Turkey having the same probative value (para. 41), Germany was not required to take into account any special circumstances in Turkey (paras 50-1).

In Ergat, 2000 the Court held that the member states were not entitled any longer to impose conditions after the periods pursuant to article 7(1) Decision $1 / 80$ had passed (paras 38-9). In that case, that article also implied a concomitant right of residence (para. 40). The rights were only lost if a ground for expulsion was given or if the person concerned left the host state for a prolonged period of time without any legitimate reason (paras 46 and 48). Thus, the failure to have a residence permit extended and the resulting temporary unlawful residence of a Turkish worker in a member state was not to entail disproportionate sanctions. A Turkish worker namely was not to be deprived of his rights under article 7(1) Decision 1/80, or to be imprisoned or deported (paras 57-8). In Eyüp, 2000 the Court relied on the de facto continued family life of a Turkish couple (para. 34), even after their divorce and second marriage, to calculate a continuous period under article 7 Decision 1/80. The Court in Kurz, 2002 transposed the case-law as to the term 'worker' from the internal market to the Ankara Agreement (para. 31) in order to qualify an apprentice as a 'worker' within the meaning of article 6(1) Decision 1/80. Mr Kurz as an apprentice also met the other requirements of that article despite the temporary nature of his employment, i. e. the due integration into the labour force and a legal, stable, and secure situation (paras 45 and 53).

Wäblergruppe Gemeinsam, 2003 established the direct effect of article 10(1) Decision 1/80 and transposed ASTI, 1991 and Commission v. Luxemburg (ASTI II), 1994 to the context of the Ankara Agreement. Consequently, it was not lawful to consider Turkish migrant workers as ineligible in elections to workers' representation bodies on the sole basis of their nationality (para. 78), although the regime established by the Ankara Agreement did not include an analogon to article 8 Regulation 1612/68 (para. 81). The Court then in Ayaz, 2004 relied on Wählergruppe Gemeinsam, 2003 to justify the transposition to the Ankara context of the part of the judgment in Baumbast, 2002 concerning a migrant worker's children. Thus, as held in Baumbast, 2002, the stepchildren of a Turkish worker belonged to his family for the purpose of article 7 Decision 1/80.

In Cetinkaya, 2004 the Court decided that the son of a Turkish migrant worker who had been born in the host state and had always lawfully lived there had to be considered as having been authorized to join the Turkish migrant worker within the meaning of article 7 Decision 1/80 (para. 23). The rights acquired on the basis of that article, in addition, were not lost when the migrant worker ceased to belong to the duly registered labour force (paras 29 and 32). Moreover, applying Orfanopoulos, 2004, the Court held that the danger to public policy exuding from an individual had to be re-assessed, if circumstances that 
arose after a deportation order had been handed down suggested that the danger was no longer present (para. 47). The Court in Dörr, 2005 added to that and the ruling in Nazli, 2000 that, since the expulsion case-law of the internal market was applicable under the Ankara Agreement, the procedural guarantees provided by Community law in expulsion cases, i. e. articles 8 and 9 Directive 64/221, applied to Turkish migrant workers as well (para. 65).

In Aydinli, 2005, the Court replied to the referring Court that a member of the family of a Turkish migrant worker, once he had fulfilled the requirements of article 7 Decision 1/80, need not have continued to fulfil them (para. 26). Such a person was not subject to the conditions of article 6 Decision 1/80, either (paras 30-1). Thus, the person need not have been integrated into the duly registered labour force. Residence in the host state on its own was sufficient. Moreover, a member of the family of a Turkish worker who came within the first paragraph of article 7 Decision 1/80 equally could lose his rights only if he represented a danger to public policy or left the host state (para. 27). This latter ruling was confirmed for the second paragraph of article 7 Decision 1/80 in Torun, 2006 (para. 25). Moreover, according to Torun, 2006, the second paragraph of article 7 also applied to descendants who were not minors any longer (para. 27).

In Gürol, 2005, the Court held that article 9 Decision 1/80 regarding access to education had direct effect and did not presuppose that the children lived together with the Turkish migrant worker under the same roof (para. 29). Moreover, given that all forms of education were covered, educational grants had to be granted on the basis of equal terms to Turkish as well as German nationals under article 9 Decision 1/80 (paras 36-8). An educational grant to study abroad - even in Turkey - was therefore not to be subject, in the case of Turkish nationals, to the stay abroad being a mandatory requirement of the curriculum of the studies pursued, whereas in the case of German nationals the stay abroad only had to be beneficial to the studies pursued and recognizable as a normal part (para. 35).

In Dogan, 2005, the Court explained that workers who fulfilled the requirements of the third indent of article 6(1) Decision 1/80 were no longer subject to article 6(2) Decision 1/80 (para. 16). Moreover, the interpretation given in Nazli, 2000 did not just apply to short periods of absence from the labour market, but also to any period short of a definitive absence from the labour market, regardless of the cause for the absence. The only proviso was that the worker was able to find employment again within a reasonable period of time (para. 23). Even a long term spent in prison did not harm the rights (para. 22). A Turkish worker therefore also had a right to seek employment under the third indent of article 6(1) Decision 1/80 and meanwhile have residence in the host state (para. 19). In Sedef, 2006 the Court somewhat tempered the otherwise strict formal criteria in article 6 Decision 1/80 for the case of a Turkish seaman who had worked for many years, in accordance with the usual practice in the métier, under consecutive short-term employment contracts. Because of the short-term nature of these contracts, formally, he only met the requirements of the first indent of article 
6(1). According to the Court the periods in between each contract during which $\mathrm{Mr}$ Sedef had not worked came within the scope of the second sentence of article $6(2)$, although he had never reported to the unemployment office (para. 56). $\mathrm{Mr}$ Sedef was therefore entitled to rely on the third indent of article 6(1). Yet the ruling was specifically tuned to the facts of the case (see paras 61, 66-7). More generally, the Court also decided that the stages of article 6(1) Decision 1/80 had to be fulfilled in turn, i. e. the third indent after the second indent (paras 37 and 43).

In Güzeli, 2006 the Court essentially bounced the case back to the national court for the assessment of whether Mr Güzeli had been duly registered as belonging to the labour force of the host state, given that he had changed employers although his work permit did not allow him to do so. Yet the Court also stated that Article 10 Decision 1/80, like article 6(1) Decision 1/80, only applied if a person was duly registered as belonging to the labour force of the host state (para. 48). However, the Court also ruled that the second sentence of article 6(2) Decision 1/80 regarding interruptions of employment only applied when rights had already been acquired under the three indents of article 6(1) (paras 43-4).

\section{Ankara more favourable than the internal market}

In Derin, 2007, the Court stuck to its interpretation that the rights in article 7 Decision 1/80 were only lost in two situations, namely prolonged absence and threat to public order. Any other aspect was irrelevant (para. 57). The Court would not hear that this implied to treat the descendants of Turkish migrant workers more favourably than those of Community migrant workers pursuant to article 10 Regulation 1612/68. According to the Court, the legal situation of the former was not comparable to that of the latter (para. 68). Article 59 of the Additional Protocol to the Ankara Agreement was therefore not violated (para. 69). This interpretation was confirmed by Polat, 2007. Additionally, the Court ruled in Polat, 2007 that, in keeping with the expulsion case-law, several criminal convictions as such did not necessarily constitute a ground for expulsion (para. 36). Derin, 2007 was further confirmed by Er, 2008. Even if a descendant who fulfilled the conditions of article 7 Decision 1/80 had never found employment, even with government help and after several years, the rights flowing from article 7 remained intact (paras 33-4).

Altun, 2008 concerned the son of a Turkish migrant worker. The migrant worker had initially come to Germany as a refugee, but had made some false representations in this regard. The Court held that during the periods required by article 7 Decision 1/80, the Turkish migrant worker had to belong to the duly registered labour force as required by article 6(1) Decision 1/80 (paras 27 and 33), else rights could not come into existence for the descendant under article 7. After the periods of article 7 had been completed, however, the criteria of article 6(1) became irrelevant for the purpose of article 7 (para. 36). Even if the Turkish worker's residence permit was withdrawn at a certain point in time, because it then turned out that the criteria of article 6(1) had not been met in the first place 
because of false representations made by the worker, the autonomous rights the descendant had acquired at that point in time by reason of the completion of the periods in article 7 were not to be questioned owing to the need for legal certainty (paras 58-60). In addition, the reason why a migrant worker had originally been granted access to a member state, namely that he had been a political refugee under the Geneva conventions, did not have an impact on the rights acquired by his family members pursuant to article 7 (para. 49).

Payir, 2008 revealed that students who worked part-time and au pairs were capable of qualifying as 'workers' within the meaning of article 6 Decision 1/80 (para. 35). The criteria for 'work' as established in the internal market case-law had to be met (para. 28), students and au pairs had to be duly registered (para. 29), and their situation had to be stable and secure (para. 30). Besides these three conditions other considerations were not relevant, bar in cases of downright fraud (paras 44 and 6). Moreover, Directive 2004/114 was not to be applied in the context of the Ankara Agreement, not even for interpretive purposes (para. 48). In Kahveci, 2008 the Court found that non-discrimination in the context of the Ankara Agreement precluded any limit on the number of Turkish football players a club in a member state could field. In deciding so, the Court effectively transposed Deutscher Handballbund, 2003 and Simutenkov, 2005, which are both explained below, to the Ankara Agreement.

Sahin, 2009, finally, concerned the administrative charges payable upon the extension of a residence permit. The Court decided that the standstill clause in article 13 Decision 1/80 did not prevent the introduction of new charges payable by Turkish nationals and Union citizens alike (paras 67 and 69). However, in the light of article 59 Additional Protocol the charges levied from Turkish nationals were not to be higher or lower than those levied from Union citizens (para. 71).

\section{Agreements with other third states}

The Court also dealt with the free movement of workers in the context of a number of other agreements than the Ankara Agreement with Turkey. In Fabmi and Amado, 2001, the Court held that the children of a Moroccan migrant worker had to reside in the Community, else neither them nor the migrant worker were entitled to rely on the principle of non-discrimination contained in article 41(a) and (3) of the Rabat Cooperation Agreement with Morocco to claim a family allowance (para. 57).

In Gottardo, 2002 the Court indirectly dealt with a bilateral convention between Italy and Switzerland which essentially provided that Italy aggregated old age insurance periods an Italian national had completed in Switzerland. According to the Court, non-discrimination of workers required Italy to extend that benefit to migrant workers who were nationals of a member state and had completed insurance periods in Italy and Switzerland (paras 33-4), in essence because that extension did not affect the balance and reciprocity of obligations between Italy and Switzerland (paras 36-7). 
Pokrzeptowicz, 2002 concluded that the principle of non-discrimination in the Europe Agreement with Poland had direct effect. In light of the text, purpose, and context of non-discrimination in the Europe Agreement there was no reason not to interpret it in the same way as in the case-law regarding language assistants developed in the internal market, notably Spotti, 1993. Given that the very same national provision was at issue in Pokrzeptowicz, 2002 as in Spotti, 1993, the ruling as to article 48(2) Treaty was transposable to the Europe Agreement (para. 39). As the rules of non-discrimination in the Europe Agreements with Slovakia and Poland were identical, the Court in Deutscher Handballbund, 2003, next transposed to the Agreement with Slovakia the ruling in Bosman, 1995 that had increased the number of Union citizens a club in a member state could field. However, this applied only to Slovakian players who had already gained access to the labour market.

The Court then transposed the ruling in Deutscher Handballbund, 2003 to the Partnership Agreement with Russia in Simutenkov, 2005, which (the Agreement) also included a directly applicable provision of non-discrimination in terms of conditions of work. With Commission v. Austria (trade unions), 2004 the Court then transposed the decision in ASTI, 1991 and Commission v. Luxemburg (ASTI II), 1994 regarding participation in workers' representation bodies to the Agreement on the European Economic Area, all Europe Agreements, and 'other agreements' (para. 47) establishing non-discrimination of workers regarding working conditions, much like the Court had done for the Ankara Agreement in Wählergruppe Gemeinsam, 2003. In Gattoussi, 2006 the Court finally transposed the ruling in El-Yassini, 1999 as to the Rabat Agreement with Morocco to the Association Agreement with Tunisia, in so far as it precluded a member state from refusing a residence permit after a work permit of a certain duration had been issued (para. 40).

Two more agreements were dealt with by the Court. In Grimme, 2009 the Court dealt for the first time with the Agreement on free movement of persons with Switzerland in the light of free movement of workers. After having held that internal market case-law was not to be transposed automatically to the Agreement, the Court decided first that the Agreement encompassed only natural persons. The freedom of establishment of legal persons was not within the scope of the Agreement. The freedom of services was limited to 90 days per year. Second, as regarded the freedom of workers, a German employee of the German branch of a Swiss company was not entitled to rely on the principle of non-discrimination in the Agreement to claim applicability of an exemption provided by German law from the compulsory affiliation to a pension scheme for members of the managing board of German companies merely because he was at the same time a member of the managing board of the Swiss parent company (para. 49). The Court also addressed the Agreement on the European Economic Area, namely in Commission v. Portugal (capital gains deduction), 2006 and Commission v. Sweden (tax deferral), 2007. The Court in these two decisions extended 
the rulings it delivered re the internal market to the Agreement on the European Economic Area (paras 40-2 and 32-3, respectively).

\section{Technicalities}

During the first decade of the millennium, the Court also interpreted several technical provisions of the directives implementing the free movement of workers. Commission v. Italy (resources), 2000 concerned the sufficient resources migrant workers, the members of their family, as well as students had to have in order not to become a burden to the host state and the proofs relating thereto. The Court on the one hand rejected the Commission's allegation that Italy had exceeded the latitude it enjoyed under these directives; on the other hand, it refuted Italy's restriction of evidence to prove sufficient resources.

In Yiadom, 2000 the Court decided that a Union citizen who had been temporarily admitted to the territory of a member state pending a decision concerning entry, but then had to wait 'for a period which [was] manifestly longer than [was] required' (para. 41) for such a decision, benefitted from the procedural safeguards in article 9, rather than just those in article 8 Directive 64/221. In Dörr, 2005 the Court found, subject to the national court's assessment, that the requirements of a review of expediency under articles 8 and 9 Directive 64/221 were not respected (para. 47). Moreover, the suspensory effect of procedures had to be automatic (paras 51-2).

\section{Driving licences}

In Commission v. Netherlands (driving licence), 2003, the Court struck down the requirement to have a driving licence registered in the host state after having transferred residence, because the formality was contrary to article 1(2) of Directive 91/439 on mutual recognition of driving licences (para. 63) and unjustifiably hindered the free movement of persons (paras 66-70). That ruling was confirmed in Krüger, 2004 in which the Court also made it plain that as a consequence a state's requirement for its own nationals to renew driving licences every 10 years amounted to reverse discrimination with which to deal was up to national law (paras 35-6). Kapper, 2004 also concerned the recognition of driving licences. According to the Court, Directive 91/439 did not leave any room not to recognize a driving licence issued in another member state, even if the host member state had concrete indications that the residence requirement had been disregarded by the state issuing the driving licence (para. 47). That point had already been established in Commission v. Netherlands (driving licence), 2003 and confirmed in an order by the Court, Da Silva Carvalho, 2003. Certain measures to restrict, suspend, withdraw, or cancel a driving licence could be taken, though. However, that possibility was not to be used to refuse indefinitely the recognition of the validity of a licence issued in another member state, in particular in case of a licence which was issued in one state after a temporary ban imposed by an another state had expired (para. 76). In Commission v. Spain (driver licence), 2004, the Court confirmed Commission v. Netherlands (driving licence), 2003 and 
added the following points. The registration of a licence could be offered on a voluntary basis (para. 61). It was sufficient to register the details of an offender at the occasion of the offence (para. 63). Roadside checks did not violate the free movement of persons or non-discrimination, even if they were selective (para. 64). Even when licences issued before the entry into force of the Directive were renewed the minimum medical standards of the Directive had to be observed (paras 77-80). Kapper, 2004 was in turn confirmed in Halbritter, 2006. Accordingly, Germany could not lawfully require the holder of a driving licence issued in Austria to comply with conditions established by German law for the re-issuing of a German licence after Germany had previously withdrawn his German licence, in particular when the person concerned had been resident in Austria when the Austrian licence had been issued (paras 29-30 and 37-8). The two cases were again confirmed in Kremer, 2006. The Court added that when a temporary ban on driving had not been ordered by Germany, recognition of a licence issued in Belgium later on could a fortiori not be refused (para. 34). In Wiedemann, 2008 the Court further clarified that case-law and qualified it to some extent. When a member state had withdrawn a driving licence and the period during which it was prohibited to apply for a new licence had passed, recognition of a driving licence issued in another member state could be refused or suspended when it was evident from the driving licence document itself or other information provided by the issuing member state that it had been issued in violation of the residence requirement pursuant to Community law (paras 69-72 and 84). Zerche, 2008 was handed down on the same day as Wiedemann, 2008 and confirmed it. Möginger, 2008 confirmed that a licence issued in a member state, while a ban on re-application had been ordered after a withdrawal in another member state, need not have been recognized by the latter state. The possibility to refuse recognition was not limited in time (paras 41-2). Weber, 2008 again clarified a detail. When a person's right to drive was temporarily suspended in one state, because the person had driven under the influence of a substance, and then later on was definitely revoked in the light of the same incident, a driving licence issued in another member state during the time of suspension need not have been recognized (paras 31-40). Schwarz, 2009 further refined that case-law. The question in Schwarz, 2009 was whether a driving licence issued by Austria before accession to the Community had to be recognized, after a subsequently issued German licence had been withdrawn due to driving under the influence of a substance and the period set by Germany during which no new licence could be applied for had expired. In the light of the case-law, the Court denied the obligation to recognize the Austrian licence, although the licence was in principle equivalent. The reason was that road safety could be compromised, because the person concerned had simply fallen back on the old Austrian licence without having undergone any kind of test of the fitness to drive (paras 89-97). Wierer, 2009 refined Wiedemann, 2008 with regard to a licence issued in violation of the residence requirement in Directive 91/439 and the evidence needed in this regard for the host state to justify a refusal to recognize a licence issued in another 
member state. The evidence admitted did not include statements made by the licence holder in the administrative procedure in the state issuing the licence, or even that state's statement not to have verified the residence requirement; it included information furnished by the host state's local authorities in charge of residence registration, but not by employers or landlords (paras 53-61).

\section{Purely internal situations}

In the 2000s the Court also developed its approach to purely internal situations and clarified it with regard to Union citizenship. In Garcia Avello, 2003 the Court decided that article 12 Treaty applied as soon as a national of one member state resided in another member state, even if he also held the nationality of the host state (paras 27-8). In Zhu and Chen, 2004, the Court found that the situation of a national of a member state who was born in another member state which he had never left was not a purely internal situation (para. 19). In Schempp, 2005 the Court decided that it was enough to bring a situation within the scope of articles 12 and 18 Treaty that a German national residing in Germany, who had never made use of his Treaty freedoms, had a tax issue with the German authorities with regard to maintenance payments made to his former wife who was resident in Austria. The reason was that the possibility for him to deduct maintenance payment from income for tax purposes in Germany was influenced by her exercising her freedom of movement (para. 24).

In Tas-Hagen, 2006 the refusal of a benefit by a member state to one of his own nationals on the ground that he resided in another member state was found not to be a purely internal situation for the purposes of Union citizenship (paras 26-8). This was confirmed in Nerkowska, 2008 (paras 28-9). In Eman and Sevinger, 2006 the Court ruled that article 19(2) Treaty did not apply to a Union citizen residing in an overseas territory who wished to vote in European Parliamentary election in the state of which he was a national (para. 53). The Court went on to examine equal treatment nonetheless only to find that a member state was precluded from drawing a distinction for voting purposes between his own nationals living in a third state and those living in an overseas territory (paras 58 and 60$)$.

In French Community, 2008 the Court dealt with a care insurance scheme established by the Flemish region in Belgium which was only available to persons residing in the Flemish region or nationals of other member states who worked in the Flemish region, but resided in another member state. The Court replied to the questions asked by the national court for two reasons, namely (i) to give the national court the possibility to exclude reverse discrimination of Belgian nationals which could be prohibited by national law; and (ii) to exclude discrimination of nationals of the member states who resided in the French region of Belgium or in Brussels and worked in the Flemish region (paras 40-1). The Court then found that the exclusion from the scheme of nationals of member states other than Belgium who resided in Brussels or the French region violated non-discrimination pursuant to articles 39 and 43 Treaty. Essentially, the residence condition was li- 
able to prevent certain Union citizens from moving to parts of Belgium (para. 48).

However, the Court also refused to examine certain situations, because they were purely internal to a member state. This was the case in Mayeur, 2008, because the spouse of a third country national had never made use of his freedoms as a Union citizen. The third country national could therefore not rely on the diploma recognition rules of the Community to have a diploma recognized in the member state concerned which (the diploma) she had obtained in a third state, although previously the diploma had already been recognized by another member state (para. 20). In Mariano, 2009 the Court refused to deal with a situation in Italy in which a survivor received lower benefits because she had not been married to the person having died in an accident. Given that all circumstances were confined to Italy, no connection whatsoever to Community law was given (paras 22-3). The Charter of Fundamental Rights did not change that assessment (para. 29). In a similar vein, the Court refused to enter into the case in Pignataro, 2009. An Italian national who had never made use of her right of free movement was not entitled to rely on her rights as a Union citizen to challenge her exclusion from the elections to the regional assembly in Sicily on the ground that she was not resident there, but elsewhere in Italy. According to the Court she was not hindered in exercising her right of free movement. The purely hypothetical perspective of her exercising her rights at a later point in time was not sufficient to establish a connection to Community law (paras 15-6).

\section{Establishment}

\section{Dentists}

In Haim II, 2000 the Court considered a language requirement for dental practitioners in the light of the freedom of establishment. While such a requirement could be justified by the need for the communication skills required to exercise the profession, in particular with patients, the Court found that the requirement was not to go beyond what such communication required. In particular, the needs of patients speaking a foreign language in the host state to communicate with dentists in their native language had to be taken into account (paras 57-60). In Commission v. Italy (dentists), 2001 the Court rejected two requirements for dentists practicing in Italy. Both requirements resulted from an unclear interpretation of certain Italian provisions. That only Italian nationals could maintain their registration in Italy as dentists when they moved to reside abroad was discriminatory (paras 31-2). The requirement for nationals of other member states to reside in Italy in the district concerned in order to be admitted to practice as dentists constituted a restriction, for it prevented dentists established in other member states from establishing a second practice or working as employees in Italy (para. 20). Both requirements, therefore, violated the freedom of establish- 
ment and workers. Italy had to bring to an end the state of uncertainty created by the interpretation of the norms concerned.

Hartlauer, 2009 developed the medical services case-law which had been formed mainly under the freedom of services. Hartlauer, a German company, was refused the authorization to establish outpatient dental clinics in Vienna and Wels in Austria. Such authorizations depended on the need for such a clinic in a region which in turn depended on different factors in each region, such as the waiting time for patients or the number of doctors per capita in the region concerned. The Court ruled that the refusal to grant the authorization for lack of need constituted a restriction of Hartlauer's access to the Austrian market and thus of the freedom of establishment (paras 37-9). That restriction concerning extra-muros treatment in kind was, in principle, susceptible of justification by the need to maintain a balanced high quality medical service open to all and to prevent serious harm to the financial balance of the social security system (paras 51-3). However, Austria had pursued those aims in a manner unsuitable for inconsistent and unsystematic. Group practises run by several dental practitioners which essentially covered the same market as outpatient dental clinics were not subject to an assessment of need (paras 54-63). Moreover, the criteria subject to which the authorization was normally granted were not sufficiently fixed and well known in advance, in part because they differed for each region (paras 64-70).

\section{Opticians}

In Mac Quen, 2001 the Belgian authorities opened criminal proceedings, because a company established in the United Kingdom offered certain new examinations of eyesight via a daughter company in Belgium. Such services were reserved in Belgium to qualified ophthalmologists, while in the United Kingdom they could lawfully be provided by ordinary opticians. The profession of ophthalmologist was not harmonized in the Community. The Court found that the four-pronged test established in Gebhard, 1995 was satisfied, namely the requirement was indiscriminate, public health concerns applied, and it was suitable and basically necessary to protect public health. That other member states were satisfied with a lower level of public health protection did not necessarily render one member state's high level of protection disproportionate (paras 26-34). However, in assessing the necessity of the restriction the national court had to factor in two points, viz. that Belgium's restriction was based on an early interpretation by Belgium's highest court and the assessment of public health concerns could possibly differ at the time given the scientific progress; the German Federal Constitutional Court had, moreover, ruled shortly before that the services the British company offered were provided safely by opticians in Germany (paras 35-6).

In Commission v. Greece (opticians), 2005 the Court rejected Greece's requirements for the operation of an optician's shop, namely (i) an authorized optician as a natural person was allowed to run only one shop; (ii) such an optician had to hold at least 50 per cent of the share capital of a company running an 
optician's shop and participate at least to that extent in the profits and losses of the company which had to be established in the form of a collective or limited partnership; (iii) an optician running a shop was allowed to participate at most in one other company owning an optician's shop. According to the Court, the first requirement (i) restricted the freedom of establishment of natural persons, while the other requirements restricted the freedom of establishment of legal persons (paras 28-9). The protection of public health did not justify those restrictions, since less restrictive measures were available, namely qualified opticians could simply be required to be present at the shop and civil liability and professional indemnity insurance rules could address the risks involved (para. 35). In Commission v. Greece (opticians II), 2009 the Court confirmed that Greece had failed to comply with the judgment for about four years and ordered Greece to pay a lump sum.

\section{Psychotherapists}

In Commission v. Germany (psychotherapists), 2007, Germany had introduced a new quota system based on regions for practices of psychotherapists. The Commission challenged the way Germany safeguarded established rights. In essence, Germany only allowed those practitioners to practice outside the quota system who had practised previously for three years under German statutory sickness insurance schemes and who wanted to continue to do so in the very same region. Even for psychotherapists who were established in Germany, comparable professional activities in other member states were not taken account of to determine whether the requirement of having practised for three years was met (para. 52). The Court held that that exclusion amounted to indirect discrimination (paras 53-9). While safeguarding established rights was a ground that could potentially justify a restriction, the measure was not necessary. According to the Court, the aim of the new system of quotas which was to limit the number of psychotherapists would not have been jeopardized, if practice in other member states would have been taken into account in all the cases of psychotherapists who were already established in Germany (paras 63-73).

\section{Pharmacies}

In Apothekerkammer, 2009 Germany's prohibition for non-pharmacists, such as the Dutch company DocMorris, to own and operate a pharmacy was at issue. In a similar vein as in Hartlaner, 2009, the restriction of the freedom of establishment inherent in Germany's prohibition was in general justifiable by public health grounds. The independence of pharmacists, a 'moderating factor' (para. 39 ) which a member state was entitled to consider as necessary to run a pharmacy in a way that avoided overemphasizing profits and that did not jeopardize the financial balance of the medical system could be factored into that assessment (paras 27-40). In contrast to Hartlaner, 2009, the German measure was appropriate, because it was consistent and systematic. The existence of internal hospital pharmacies as well as the possibility for non-pharmacists within narrow con- 
fines to run an inherited pharmacy both complied with those criteria; so did the fact that pharmacists under certain conditions could run three branches of a pharmacy, while remaining responsible for the overall operation (paras 42-50). Finally, given the member states' large discretion less restrictive, but equally effective measures were not available (paras 52-8). With almost identical reasoning, though also extending to the free movement of capital, the Court then approved Italy's requirements to run pharmacies in Commission v. Italy (pharmacies), 2009. Italy also limited the right to operate pharmacies to pharmacists and to companies composed exclusively of pharmacists. In addition, companies distributing pharmaceutical products were not allowed to acquire stakes in public municipal pharmacies.

\section{Lawyers}

In Luxembourg $v$. Parliament (lawyer directive), 2000 the Court rejected Luxembourg's challenge of a new lawyer directive governing practice under the title acquired in the 'home' state, viz. Directive 98/5. Equal treatment was not violated by the possibility for lawyers admitted to the bar in a member state to practise fully in the host state under the 'home' state title, as the situations of a 'domestic' lawyer and a lawyer coming to practice in the host state under her 'home' state title were not comparable (paras 24-8). The protection of the consumer was sufficiently guaranteed by the directive (para. 43). Article 57(1) Treaty was, moreover, the right legal basis for the directive, as it was about the recognition of professional titles rather than the rules governing the professions pursuant to article 57(2) Treaty (paras 56-7).

Wouters, 2002 also concerned lawyers. In the Netherlands, the bar association prohibited multidisciplinary partnerships. Lawyers were therefore not allowed to offer their services together with accountants. Most of the judgment dealt with competition law. However, the freedom of establishment and services was also concerned, since the bar as a private association regulated establishment and services collectively. The Court found that any possible restriction of the freedoms inherent in the prohibition were justified - like the restriction of competition - by the rules of professional conduct established in the Netherlands, namely the need for lawyers to be independent and maintain professional secrecy and the prevention of conflicts of interests (para. 122, referring to paras 97-108).

In Commission v. Italy (lawyers), 2002 the Court held that Italy could not lawfully require a lawyer to reside in the judicial district where she or he was admitted to practise, because owing to the freedom of establishment it had to be possible for lawyers to have more than one place of work (paras 27-8). Moreover, the aptitude test Italy required foreign lawyers to pass did not live up to the requirements of Directive 89/48 on a general system of recognition, because the subjects to be tested and the yardsticks applied were not known in advance. That resulted in a situation of fluidity and uncertainty (paras 51-4). Apart from that, the Court struck down the requirement Italy imposed on foreign lawyers practis- 
ing in Italy not to have an establishment in Italy, for it was irreconcilable with the freedom of services; the freedom allowed for some infrastructure in the host state (paras 22-3).

In Mauri, 2005, admission to practice as a lawyer came under scrutiny. It was not the exam to be taken by candidates as such that was at issue, but rather the composition of the committee examining a candidate's ability. The Court, however, did not find any restriction of the freedom of establishment in that the committee concerned in Italy included, apart from two judges and one professor, two lawyers who acted as president and vice-president of the committee. In any event, a possible restriction would have been justified by the need to ensure the proper qualification of candidates. After all, lawyers themselves were particularly well placed to assess the abilities of candidates (paras 43-5). Moreover, the state retained important supervisory powers (paras 32-5). An additional dimension of the case was that the Court entered the merits, although all the facts of the case exclusively concerned Italy. The Court accepted the argument that the national court required an answer to its question in order to exclude reverse discrimination, thus disregarding that the situation was purely internal to Italy (para. 21).

With Wilson, 2006 the Court came back to Directive 98/5. Luxembourg had made the admission to practice as a lawyer under the 'home' state title subject to a language test. The Court found that the Directive had completely harmonised the conditions. The aims pursued by such a test were sufficiently safeguarded by the Directive. There was therefore no room left for such an exam (paras 66-76). The Court, in addition, elaborated on the composition of the instance hearing appeals against refusals to be admitted to practice in the light of the fundamental right to effective judicial protection. On the same day Wilson, 2006 was handed down the Court in Commission v. Luxembourg (lawyers), 2006 dealt with other aspects of Luxembourg's implementation of Directive 98/5. Apart from fully confirming the ruling sent in Wilson, 2006 regarding the language test, the Court held that lawyers practising under the 'home' state title in Luxembourg were not to be barred from providing certain services on behalf of companies, if such services could be provided by domestic lawyers, because full access to the profession of a lawyer had to be granted, bar the exceptions contained expressly in the Directive (paras 57-60). Finally, the Directive equally precluded the requirement for lawyers to submit proof of continued registration in the 'home' state on a yearly basis (paras 67-70).

Eschig, 2009 concerned the legal expenses insurance Directive 87/334. The Court decided that the Directive included a general right of the insured person to chose the lawyer representing her or his interests, even in the absence of a conflict of interest. The insurer could, therefore, not lawfully retain the right to appoint a lawyer for mass tort claims proceedings. 


\section{Pay slips for workers}

In Payroll, 2002 Italy had reserved the service of issuing the pay slips of workers of companies with less than 250 employees to companies staffed exclusively with certain qualified employment consultants. The Court found that this measure constituted an obstacle to the freedom of establishment (para. 27). The national court had to assess whether it was suitable for the protection of the workers receiving the pay slips, or whether the service consisted merely in implementing instructions and was thus of administrative nature (paras 34-5). In any event, the rule went beyond what was necessary to protect workers, as for no apparent reason it applied only to small companies with less than 250 employees (para. 37).

\section{Games of chance}

Gambelli, 2003 concerned a similar gambling constellation as Zenatti, 1999. In the latter case the Court had owing to the question referred by the national court exclusively applied the freedom of services. In Gambelli, 2003 the Court in addition applied the freedom of establishment. A British company which was authorized to offer gambling services in the United Kingdom collected bets in Italy via agencies without having obtained the licence required in Italy. That the freedom of establishment and services was restricted was undisputed, in particular because the conditions under which an authorization would have been obtainable worked to the effect that one Italian licence holder enjoyed a monopoly in gambling services (paras 47-9). However, in applying the four-pronged Gebhard, 1995 -test the Court held that national legislation had to pursue the aims of gambling legislation in a consistent and systematic manner to be suitable for justification (para. 67). Italy notably could not lawfully insist on a licence requirement, while denying such a licence to companies established abroad where they were duly authorized for gambling purposes, in the name of reducing gambling, whereas at the same time actively encouraging gambling with the only Italian service provider pursuing the aim of collecting more taxes (paras 68-9). Furthermore, the national court had to ensure that the licence requirement was applied indistinctly and penalties for violating it were proportionate (paras 71 et seq.).

Commission v. Greece (gaming), 2006 also concerned the entertainment and gaming industry. Greece had prohibited the public operation of all electric, electromechanical and electronic games, including all computer games, on public and private premises outside casinos. The Court looked at the prohibition through the lenses of the free movement of goods first, finding an unjustified restriction, and then the freedom of establishment and services. The Court ruled that the prohibition prevented persons lawfully offering those services in other member states from establishing themselves in Greece. Similarly, the prohibition prevented the operation of gaming machines, which was a service (paras 52-4). Those restrictions were, moreover, not justified by the grounds argued in Schindler, 1994 and Läärä, 1999, namely the protection of consumers and public order, since the activities prohibited were not comparable to games of chance. In particular, they were not played with a view to winning money (para. 36). Ac- 
cording to the Court, even if the justification based on public order as such was not precluded, less restrictive measures than an outright prohibition would have been available, like technical and organisational measures (paras 39-40). In Commission v. Greece (gaming II), 2009 the Court then ordered Greece to pay a penalty and a lump sum, because Greece had not brought an end to the violations.

In Placanica, 2007, the Court followed up on Zenatti, 1999 and Gambelli, 2003 and again dealt with games of chance offered in Italy. In essence, Italy had tendered a thousand licences for each sports and horse race betting activities. Listed companies were not allowed to participate in the tender procedure though, for Italian law necessarily required that the owners of the licensed companies were clearly identifiable at all times. That requirement worked to exclude the major service providers established in member states other than Italy, since they were all public companies. Consequently, the Italian agents of a company listed and licensed in the United Kingdom were subject to prosecution in Italy for having offered betting services without the prerequisite licence. According to the Court, the objective of reducing gaming opportunities did not justify the restrictions inherent in the licence and the tender requirements, because Italy pursued a policy of expanding betting and gambling to raise revenues. However, the aim of channelling betting and gambling away from illegal to controllable operators could provide such justification (para. 55). Yet, the blanket exclusion of listed companies from the tender procedure was unnecessary to achieve that aim. Information on owners and representatives of listed companies could be gathered as an alternative to a downright exclusion of the companies concerned (para. 62). Placanica, 2007 was backed up on the very same day it was handed down by four decisions dealing with identical constellations, namely D'Antonio, 2007, Damonte, 2007, Di Maggio, 2007, and Gallo, 2007.

\section{Taxation}

Baars, 2000 concerned an exemption from Dutch wealth tax which was only granted when substantial long-term shareholdings were held in companies established in the Netherlands. Mr Baars, a Dutch national resident in the Netherlands, was denied the exemption for his holdings in a company established in Ireland. According to the Court, the freedom of establishment was violated. A Dutch national was entitled to invoke that freedom against the member state of which he was a national (paras 28-9). When the shareholder exercised definite influence on the company concerned, the difference in treatment based on the seat of the company hindered the freedom of the shareholder to establish himself abroad (paras 30-1). (Where definite influence was not exercised over the company, free movement of capital was hindered; paras 20-2.) The hindrance was not justified, since the wealth tax did not correspond in any way to the taxation of a company's profits (paras 39-40).

De Lasteyrie du Saillant, 2004 also concerned taxation. In specific cases, France levied a tax on latent increases in the value of securities in companies 
subject to taxation in France when the holder of the securities transferred residence to another member state. In case the taxpayer stayed in France, the tax only became due when the increase in value was actually realized. The exit tax could be suspended when a sufficient guarantee was lodged, a declaration was submitted, and a representative in France was designated. In that case, the duty to pay the tax lapsed after five years, if the increase in value was not in fact realized. A tax levied by another member state on the same increase in value was credited in any case against the French tax. The Court held that the freedom of establishment was restricted, because persons were dissuaded from leaving a member state. That applied even if a national of a member state wanted to leave that member state and if the restriction was minor. The conditions to be fulfilled for the suspension of the tax, in particular the guarantee, constituted a restriction, too (paras 42-8). The restrictions were not justified by the prevention of tax avoidance, for the French approach was not designed exclusively to counteract short-term transfers of residence undertaken to escape taxation. The taxation of latent increases in value could be limited to cases of relatively brief stays abroad (paras 51-7). The coherence of the French tax system did not provide justification, either. The direct link in the sense of Bachmann, 1992 between the postponement of the taxation of increases in value and the collection at the moment when the taxpayer transferred residence was not given. The aim of the French exit tax was to prevent tax evasion, rather than to tax increases in value generally (paras 63-7). In N, 2006 a similar exit tax on latent increases in the value of shares as in De Lasteyrie du Saillant, 2004 was at issue. The freedom of establishment was concerned, because the shares conferred substantial influence on the company concerned (para. 28). However, the Court found that the restriction of the freedom of establishment inherent in the Dutch tax at issue was, in the absence of harmonizing measures, justified by the proper allocation of the power to tax increases in the value of shares among the member states, i. e. by the principle of territoriality (paras 46-7). Yet to avoid going beyond what was necessary in the light of that aim, the lodging of a security to guarantee payment of the tax debt in case that payment was deferred, could not be required. Moreover, decreases in the share value which occurred after residence had been transferred had to reduce the actual tax debt when the payment of the tax had been deferred (paras 51-4 and 57).

In Conijn, 2006 deductions for the purpose of direct taxation were at stake. Mr Conijn resided in the Netherlands, while he was established in Germany. $\mathrm{He}$ gained less than 90 per cent of his total income in Germany and sought to deduct the cost of the advice he had needed to file the tax declaration in Germany from his taxable income. However, German law allowed such a deduction only for persons fully taxable in Germany, i. e. mostly residents. The Court found that residents and non-residents were in comparable situations with regard to the deduction of the cost of tax advice, since both of them were in need of similar advice given the complexity of national tax law. The cost of the advice was, moreover, linked directly to the income taxed in Germany in both cases. 
The freedom of establishment thus precluded the indirect discrimination inherent in Germany's refusal to grant non-residents the deduction (paras 22-4). Meindl, 2007 also concerned direct taxation in a Schumacker, 1995-like situation. When one spouse was resident in Austria and received a tax-free children allowance there, while the other spouse resided in Germany and generated the entire taxable family income through self-employment there, according to the Court, the freedom of establishment required Germany to disregard the Austrian children allowance and to treat the couple, tax-wise, as if they both resided in Germany. Consequently, Germany had to apply the regular joint assessment.

As discussed under the freedom of workers, the Court in Commission v. Denmark (insurance taxation), 2007 dealt with the requirement that a pension and life insurance institution had to be established in Denmark for tax relief to be available to insured persons subject to direct taxation in Denmark. The Court found that such an approach did not only restrict the freedom of service provision by foreign insurers as well as the freedom of recipients in Denmark to receive services abroad, but also the freedom of self-employed persons and workers to move to Denmark (para. 44). Those restrictions were not justified, since the cohesion of the Danish tax system was not sufficiently threatened within the sense of Bachmann, 1992. A risk arose exclusively when an insured person left Denmark's fiscal jurisdiction right before the pension became payable, while tax relief was refused in other situations, too (paras 72-4). The restrictive measure was not required by the need to supervise taxation effectively or to prevent tax avoidance, either (paras 52-8).

In Talotta, 2007, the Court addressed a distinction drawn by Belgian tax law. When a person resident in Luxembourg who was established in Belgium had failed to submit a tax declaration based on which his income taxable in Belgium could be assessed, a tax based on a minimum tax basis became due, because the person was a non-resident taxpayer. If he had been a resident taxpayer a different method to estimate the tax due would have been applied, namely either the income taxable in Belgium would have been estimated on the basis of the income of three taxpayers in comparable situations or a flat-rate method of taxation would have been applied on the basis of signs and indications that the person concerned was indeed better off than indicated by the income accounted for (paras 21-2). The Court decided that the situations of resident and non-resident taxpayers pursuing a self-employed activity in Belgium were comparable. A distinction could therefore not be drawn on the basis of residence, else non-resident taxpayers would be subject to indirect discrimination (paras 24-6 and 31). The practical difficulties to assess the tax due from a person who pursued an activity in Belgium and was resident in Luxembourg were the same as when the person resided in Belgium and pursued a self-employed activity in Luxembourg. Those practical difficulties could be overcome by exchanging information based on $\mathrm{Di}$ rective $77 / 799$ (paras $28-9$ ).

In Filipiak, 2009 the Court invalidated the way Poland's tax law dealt with social security contributions paid by a Polish national who was resident in 
Poland and pursued a single professional activity in self-employment in the Netherlands. This self-employed activity was compulsorily subject to social security contributions in the Netherlands pursuant to Regulation 1408/71, while those contributions were not factored into the income taxation in the Netherlands (para. 51). The Court held that the situations of a person who contributed to the social security system in Poland and a person who contributed to the system of another member state were comparable, since both were subject to unlimited tax liability in Poland (paras 66-70). Therefore, Poland had to treat social security contributions made in the Netherlands in the same way in terms of taxation as those made in Poland, i. e. Poland had to allow deductibility (para. 63), else the freedom of establishment and services were breached. That the Polish constitutional court had not rendered invalid the relevant Polish act right away was irrelevant, as any Polish court was directly obliged not to apply the act, since it was contrary to the Treaty (paras $82-4$ ).

\section{Car registration}

Nadin and Durré, 2005 again after Commission v. Denmark (car registration), 2005 concerned the registration of company vehicles and the tax imposed on that occasion. In Nadin and Durré, 2005, Belgium required the registration of a vehicle along with the payment of a tax, when a person resident in Belgium was established as a self-employed person in another member state and was provided, based on that establishment, with a 'company' car. After having directed the national court to assess whether the persons concerned were indeed self-employed, the Court re-applied the ruling delivered in Commission v. Denmark (car registration), 2005 to self-employed persons (paras 36-7 and 41-2). Essentially, the vehicle's registration in the member state where the person concerned was resident could lawfully be required, if the vehicle was used there on a permanent basis. In addition, the Court rejected the justification of the restriction on the grounds of road safety and environmental protection (paras 49 and 52). Nadin and Durré, 2005 was confirmed in all aspects in Schmitz, 2006. In Vandermeier, 2008 the Court again confirmed the approach and held that it also applied in the case of a self-employed journalist who pursued his professional activity in another member state, had leased the car himself and was not the director of a company, but a regular natural person (paras 34-5).

\section{Diploma}

Neri, 2003 was at the nexus between diploma recognition and establishment. A company established in the United Kingdom offered courses in Italy via branches to prepare students for the bachelor degree to be awarded by a university in the United Kingdom. The company had an agreement to that effect with the British university concerned. The students were enrolled with the British university. Italy refused to recognize the bachelor diplomas awarded in the United Kingdom as a result of the preparatory courses in Italy. According to the Court, the freedom of establishment was restricted, because non-recognition of the diplomas had the 
effect that students were deterred from seeking those educational services provided by branches in Italy (paras 43-4). While maintaining a high standard of university education was a reason apt to justify a restriction of the freedom of establishment, non-recognition of the diploma awarded was not a suitable measure, since it was only applied when Italian nationals had obtained such a diploma. Moreover, Italian universities were allowed to offer similar courses under comparable arrangements within Italy (para. 47). Finally, Italy's categorical nonrecognition also went beyond what was required in that it precluded any assessment of the concrete situation (paras 49-50).

\section{Private security}

Commission v. Portugal (private security), 2004 concerned the freedom of services as much as the freedom of establishment. To be allowed to provide private security services certain conditions had to be fulfilled in Portugal. The provider had to be constituted as a legal person with a minimum share capital. An establishment in Portugal and an authorization by the Portuguese state were also necessary; and employees had to be in possession of a Portuguese professional certificate. Relying on Schnitzer, 2003, a freedom of services case, the Court reiterated that an abstract rule did not exist to determine the duration and frequency of services necessary to distinguish them clearly from establishment. The freedom of services was possibly concerned though, even when the services were provided over a long time span like more than one year (paras 26-8). The Court then went on to reject each of Portugal's requirements. The minimum share capital went against the grain of both the freedom of establishment and services and was not justified by the protection of creditors (paras 53-4), as did the requirement to be constituted as a legal person for excluding natural persons and secondary establishments (paras 42-3). The authorization requirement was also rejected, because it created a double burden and was not necessary to ensure supervision (para. 60); so was the requirement to be established (paras 33-4). Finally, the condition of having a Portuguese certificate violated the freedom of workers and services for it created a double burden for service providers (para. $66)$.

\section{Bovine semen}

In Commission v. France (insemination), 2008, the Court dealt with certain requirements in French law for services related to insemination with bovine semen. Semen had to be stored at specific centres which enjoyed territorial exclusivity. Each service provider had to have a licence which was subject to an agreement with a service centre. The conclusion of such an agreement was subject to the discretion of the centre concerned. The Court found that the territorial exclusivity and the need for an agreement violated the freedom of establishment, while the exclusivity and the licence requirement including the need for an agreement contravened the freedom of services (paras 53-55 and 64-66). The restrictions were not justified, as the protection of pure-bred bovine stock had been harmo- 
nized in the Community and they were not necessary for the collection of data on insemination (paras 73-81). The protection of public health did not require exclusive rights and a licence subject to a discretionary agreement, either (paras 91-5). The necessities of food safety, traceability of semen, and of town planning were, moreover, not proven to a sufficient degree.

\section{Family members}

Jia, 2007 was already discussed under free movement of workers above, because it was mainly related to Akrich, 2003 and Metock, 2008. Technically though, it concerned the freedom of establishment and Directive 73/148. The Court in Jia, 2007 left the member states an option, namely each member state could - but did not have to - require a third country national who was the parent of the third country national spouse of a migrant worker to have had legal residence in another member state before that parent was entitled to rely on the right to family reunification pursuant to Community law (para. 33). Moreover, the Court clarified the concept of 'dependence'. The situation of dependence of the relative must have existed in the state of origin or the state where the person concerned had been resident (para. 37).

\section{Cars}

In Commission v. Italy (motor insurance), 2009 Italy had laid down an obligation to contract for companies that offered insurance policies for third-party motor vehicle liability. The Court found that access of foreign insurance companies to the Italian market was impeded, since the obligation to contract constituted a substantial interference with the liberty to contract which companies normally enjoyed and in particular required insurance companies to adapt their policies (paras 66-71). However, that restriction of the freedom of establishment and services was justified by the need to protect victims of road traffic accidents (paras 74-82). The restriction was proportionate given that Italy had shown that young drivers in southern Italy would have difficulties taking out insurance policies without the obligation to contract and that the rates were still subject to variation based on statistical evidence (paras 87-91). Moreover, problems of equal treatment under Italian law would have arisen, if the obligation to contract was limited to southern Italy (para. 92). Finally, two complaints by the Commission relating to Directive 92/49 were rejected.

In Commission v. Portugal (vehicle inspection), 2009 Portugal had required companies that tested vehicles on roadworthiness to have an authorization which was only granted, if it was in the public interest to grant it, the company had a share capital of 100 '000 Euro, the objectives of the company were limited to providing that service, and certain incompatibility rules for shareholders, managers, and directors of the company were respected. The Court found that those conditions restricted the freedom of establishment, in particular since the public interest criterion was subject to potentially arbitrary discretion. Justification by the public authority derogation, though not inconceivable for non-dis- 
criminatory measures as such (para. 33), was not plausible. If at all, only the second stage of the test, i. e. the attachment of the certifying badge to the vehicle after the actual test, could possibly come within the scope of the derogation. However, in this stage the companies concerned were supervised by the public authorities and did have neither the independence in decision-taking nor the power of coercion characteristic of public authority (paras 38-44).

\section{Ankara}

In Savas, 2000 two Turkish nationals had stayed in the United Kingdom after their tourist visas had expired and had opened a business there. The Court ruled that article 13 of the Ankara Agreement with Turkey did not have direct effect in the absence of the implementing provisions mentioned therein, in contrast to the standstill clause in article 41(1) of the Additional Protocol to the Ankara Agreement. However, that standstill clause was not capable by itself of conferring a right to establishment in the case at hand, since in analogy to the case-law developed for workers under the Ankara Agreement the situation of a person who remained in the host state after a tourist visa had expired was not to be considered stable and secure. Such a person was therefore not entitled to claim a residence permit. Each member state on its own regulated the first admission of Turkish nationals to its market (paras 63-7). In Tum, 2007, the Court again ruled on the basis the freedom of establishment under the Ankara Agreement. According to the Court, the standstill clause in article 41(1) of the Additional Protocol to the Ankara Agreement, which had been at stake already in Savas, 2000 , prevented the introduction of any new procedural and substantive requirements for the establishment in a member state. The standstill clause notably also covered the conditions of first admission to a member state, while not in itself conferring a right of first admission (paras 52, 55, 58, and 63).

\section{Europe Agreements}

In Kondova, 2001 a similar situation as in Savas, 2000 came up under the Association Agreement with Bulgaria. A Bulgarian national had made false representations when entering the United Kingdom, and later on began to work as a selfemployed cleaner there, after having married a third country national having indefinite leave to remain in the United Kingdom. The Court ruled that the freedom of establishment in article 45(1) of the Europe Agreement with Bulgaria had direct effect. However, despite the same wording of the freedom of establishment in the Europe Agreement as in the Treaty the case-law developed for the internal market was not to be applied mechanically under the Europe Agreement, since the aims of the internal market and the Agreement differed (paras 50-5). Hence, the freedom of establishment under the Europe Agreement did not automatically entail the same right of entry and residence as in the internal market. While the economic needs of the British market, nationality, and residence were all banned by the Europe Agreement as criteria under the freedom of establishment, a system of prior control of the requirements in the Europe Agreement 
was compatible with it. More specifically, to prevent illegal immigration the person concerned could lawfully be required not to make false statements upon entering the United Kingdom, and, if she did nonetheless do so, be forced to file a new application from Bulgaria or another state outside the United Kingdom. Such a person had placed herself wilfully outside the protection of the Europe Agreement and was not entitled to invoke it (paras 77-80 and 87). The family life had to be respected, though (para. 88). Shortly after Kondova, 2001 the Court applied an identical approach under the Europe Agreements with Poland and the Czech Republic in Gloszczuk, 2001 and Barkoci, 2001, respectively. However, in Barkoci, 2001 an abuse had not been committed by the Czech nationals concerned. Yet those Czech nationals had to meet the substantive requirements which were tolerated by the Europe Agreement and in case of failure to do so could lawfully be required to file new applications from the Czech Republic, even if they had been admitted temporarily to the United Kingdom on grounds of human dignity and solidarity (para. 78).

Jany, 2001 again concerned an activity under two Europe Agreements, namely that with Poland and that with the Czech Republic. Polish and Czech prostitutes claimed to be established to conduct business in the Netherlands. The Court applied the same principles as it had in Kondova, 2001. Moreover, according to the Court, internal market case-law could be applied to determine whether an activity was covered by the freedom of establishment (paras 37-8). Prostitution was an economic activity in the sense of the Europe Agreement (para. 48). Whether a restriction of prostitution was covered by a derogation, notably the public order derogation, was essentially for the national institutions to assess. Certainly though, similar restrictions had to be enforced against Dutch nationals as for nationals from the associated states. That was not the case in Jany, 2001 (para. 62). Finally, a member state was not to apply a general presumption that prostitutes were employed. Rather, a case-by-case assessment was necessary (paras 67-70). (The distinction between employment and self-employment was relevant, because the admission requirements were not the same for the two categories under the Europe Agreements.)

In Panayotova, 2004 the Court again ruled on the basis of the Europe Agreements. The Court reiterated that the relevant Europe Agreements did not confer a right for persons to submit an application in the host state to become established there, in that case the Netherlands, when they were present there illegally or based on a tourist visa. Rather, national law could lawfully require an application in the 'home' state via the consular representation (para. 24). The Court added that procedural guarantees and fundamental rights had to be respected (paras 26-7). Moreover, even when the host state authorities did not have any discretion pursuant to domestic law and the substantive requirements of the Europe Agreement concerned were manifestly met they were entitled automatically to reject an application made on the basis of illegal or tolerated presence, else the conditions of the Europe Agreements ran the risk of being circumvented (paras 29-38). 
In Commission v. Austria (self-employment), 2008 the Court dealt with a measure Austria had adopted to prevent circumvention of the transitional limitation of access to the labour market for workers from the new central and eastern European member states which (the limitation) was contained in the Act of Accession. Austria had claimed that workers from the new member states established themselves in Austria as self-employed persons in partnerships and limited liability companies and thereby bypassed the limitations applying to employed persons. However, the Court found that the prior authorization requirement for such entities which had been introduced by Austria and was applicable in the case of nationals from the new member states established a difference in treatment which was contrary to the freedom of establishment. The authorization was essentially granted only if the person concerned proved that she or he was not working as an employed person. Moreover, during the authorization proceedings 'work' was not to begin yet (paras 29-30). Being discriminatory, the measure was amenable to justification solely by the express grounds provided by the Treaty, but the public policy ground did not hold, since it would have been sufficient to provide the authorities with the information they needed. The persons concerned could then have immediately begun with their activities and the authorities would have undertaken controls later on (paras 31-40).

\section{Switzerland}

Stamm, 2008 was the first judgment that applied the Luxembourg Agreement on Free Movement of Persons with Switzerland. (Grimme, 2009 was handed down later on, see above.) Mr Stamm was a farmer established in Switzerland who had leased farmland across the border in Germany. Could such a farmer, as a selfemployed frontier worker, rely on the equal treatment clause contained in the Luxembourg Agreement? The Court, reasoning mainly in analogy to employed frontier workers (paras 41-3), answered in the affirmative.

\section{Purely internal situations}

In Kurt, 2008, the Court refused to address the question asked by the Austrian court on the ground that the situation was purely internal to Austria. Mr Kurt had complained that he was only allowed to work as a teacher for driving instructors in Austria, but not to run his own school, while German nationals with an educational background comparable to his were allowed to run their own school in Austria based on the freedom of establishment. Moreover, he himself was entitled to run such a school in Germany. According to the Court, all aspects of the situation were confined to Austria. It was up to national law to address reverse discrimination (paras 21-3).

\section{Secondary law}

In the 2000s, the Court also in a number of judgments applied further, rather technical secondary legislation which implemented the freedom of establishment, though without elaborating on that freedom itself. In Centrosteel, 2000 the 
Court applied Directive $86 / 653$ on self-employed commercial agents by confirming the judgment in Bellone, 1998. In Ingmar, 2000, Caprini, 2003, Mavrona, 2004, Poseidon, 2006, Honyvem, 2006, Chevassus-Marche, 2008, and Semen, 2009 the Court again interpreted that Directive. In Vogel, 2003 the Court applied Directive 78/687 concerning dental practitioners.

\section{Open skies}

The opens skies judgments, eight of which had been handed down on 5 November 2002 (Commission v. Austria (open skies), 2002; Commission v. Belgium (open skies), 2002; Commission v. Denmark (open skies), 2002; Commission v. Finland (open skies), 2002; Commission v. Germany (open skies), 2002; Commission v. Luxembourg (open skies), 2002; Commission v. Sweden (open skies), 2002; Commission v. United Kingdom (open skies), 2002) with one trailing in 2007 (Commission v. Netherlands (open skies), 2007), mainly dealt with the powers of the Community and the member states to conclude agreements with third states, namely in these cases agreements allowing free air transport with the United States of America (see the main part of Commission v. Denmark (open skies), 2002). One aspect of the cases, however, concerned the freedom of establishment. The open skies agreements with the United States contained a clause of ownership and control of airlines. That clause allowed the United States to withdraw the licence of an airline which had been designated by the other party of the treaty, if no substantial part of ownership and effective control over the company was vested in the state party or nationals of the parties to the specific treaty, for instance in the United Kingdom or British and/or American nationals (para. 47 of Commission v. United Kingdom (open skies), 2002). The Court found that the freedom of establishment applied in the air transport sector, in contrast to the freedom of services (paras 39-40), even if the company established in a member state provided air transport exclusively towards a third country (para. 43). Owing to equal treatment, a member state was under the obligation to grant nationals of other member states the benefits provided by treaties with third states, as held in Saint-Gobain, 1999 and Gottardo, 2002 (para. 46). The clause treated nationals of other member states and companies established there less favourably, as the United States were obliged to grant a licence when an airline operator of a state party (or one connected thereto) was concerned and could just exceptionally withdraw it, while they were always free to exclude airline operators connected to the other member states (paras 48-50). The public policy and safety derogations did not exempt the distinction, since it was too general to address a threat to the fundamental interests of society, for it was not limited to airlines that actually posed a threat and there was no direct link between the threat and the discrimination (paras 58-9).

\section{Legal persons and taxation}

The freedom of establishment of companies more generally occupied the Court in a large number of cases. Germany v. Commission (Länder), 2000 was one 
such case, though it mainly concerned state aid. Yet the Court found that Germany's limitation of a tax concession, namely the carrying forward of investments in the new German Länder, to companies established in Germany, thus in effect excluding foreign companies operating via an establishment in eastern Germany, violated the freedom of establishment (para. 86). AMID, 2000 was a case of company establishment in which the Court declared unlawful Belgium's requirement to offset for company tax purposes a Belgian company's losses made in Belgium against profits made by its permanent establishment in Luxembourg, essentially because that resulted in a situation where the losses made in Belgium could not be deducted anywhere from taxable profit, whereas such losses would have been deductible had the permanent establishment not been in Luxembourg, but in Belgium (para. 23).

\section{Dividends}

Metallgesellschaft, 2001 developed the case-law on dividends. The law of the United Kingdom made available a regime called group income election only to groups the parent company of which had its seat in the United Kingdom. Group income election essentially had the effect that a tax on intra-group dividends which operated as an advance payment of corporation tax did not become due. The result was a cash-flow disadvantage for foreign groups with subsidiaries in the United Kingdom. According to the Court that constituted a restriction of the freedom of establishment (paras 43-4 and 53-4) which was not justified, notably by the need to maintain the cohesion of the tax system. A direct link did not exist between the cash-flow disadvantage due to the tax on dividends, i.e. the refusal to grant group income election, and the exemption of foreign parent companies from profit taxation as regarded dividends received from subsidiaries in the United Kingdom, since such dividends were not subject to profit taxation in any case regardless of whether the parent company had its seat in the United Kingdom or in another member state (paras 69-73).

Lankhorst, 2002 added to the case-law on taxation of dividends. Germany treated interest paid on the basis of an intra-group loan as a covert distribution of profits, viz. as dividends, to the extent that the loan was not at arm's length and taxed it accordingly. Such an approach was applied almost exclusively to foreign parent companies - such as Lankhorst which was a German subsidiary of a foreign parent company - technically because they did not have any tax credit in Germany. According to the Court, the freedom of establishment was restricted (paras 27-32). The approach was too general to be justifiable by the need to prevent tax evasion. The tax advantage necessary for justification by the cohesion of the tax system was also absent (paras 37-42).

\section{Incorporation}

In Ueberseering, 2002, a German court had refused, in application of the principle of the company seat, a Netherlands corporation, in which all the shares had been acquired by two German nationals resident in Germany, the right to stand 
before court. The Court found that the freedom of establishment which applied in such a situation despite the appearance created in Daily Mail, 1988 was violated, for what Germany's approach essentially required was the winding-up of the Dutch company and the consequent re-incorporation in Germany. That approach thus unjustifiably negated the freedom of establishment (paras 81 and 93).

In Inspire Art, 2003 the Court mainly based on Centros, 1999 struck down some of the Dutch requirements for the registration of a branch. Inspire Art was a company formed under the law of England and Wales with a sole director who resided in the Netherlands. It was founded solely for the purpose of doing business in the Netherlands via a branch. In such a case, however, the Netherlands imposed requirements for the registration of a branch some of which, according to the Court, were contrary to provisions of the Eleventh Council Directive 89/666 (paras 55-72). In addition, the branch registration requirements for the foreign company concerned to have a higher minimum share capital and for the directors of the company to be subject to stricter liability than in the case of a Dutch company constituted obstacles to the freedom of establishment (para. 101). Those obstacles were not justified by the prevention of abuse, for the Dutch measure was too general, or the protection of creditors, for Inspire Art clearly displayed that it was a foreign company (paras 135-40).

\section{Taxation of capital gains and profits}

$X$ and Y, 2002 rejected Sweden's approach to the taxation of capital gains. In short, Sweden deferred taxation when shares were transferred at undervalue to a company established in Sweden, but not when the transferee was a company established abroad or when it was a Swedish corporation in which a foreign company had a holding (see paras 30-1). The consequent deterrent effect qua cash flow disadvantage amounted to a restriction of the freedom of establishment and the freedom of capital (paras 36 and 38) which was not justified, in particular by the cohesion of the Swedish tax system which was guaranteed by the relevant double taxation convention and in any event could be safeguarded by less restrictive means (paras 53-9). X and Y, 2002 was confirmed in De Baeck, 2004. Belgium's tax on increase in value when shares were sold to foreign companies was equally contrary - in fact, a fortiori contrary since the alternative was not the deferral of taxation (para. 24) - to the freedom of establishment and the freedom of capital.

In Bosal, 2003 Dutch law required that the cost incurred by Dutch parent companies through foreign subsidiaries were indirectly instrumental for creating a profit taxable in the Netherlands to be deductible from taxable profits. While not precluded by the relevant directive, namely Directive 90/435, the Court found that approach to be contrary to the freedom of establishment for having a dissuasive effect (para. 27). The restriction was not justified by the logic of Bachmann, 1992 of the cohesion of the tax system for lack of a direct link or by the principle of territoriality (paras 31-40). 


\section{Sight account with banks}

With Caixa-Bank, 2004, the Court was confronted with a prohibition in French law for banks to offer remuneration on sight accounts. Like all banks operating on the French market, a French bank which was the subsidiary of company established in Spain was prohibited to offer interest on sight accounts. The Court found that prohibition to violate the freedom of establishment, since it prevented banks established in other member states from penetrating the French market. It blotted out the price of services as a parameter of competition and hindered banks in raising capital (paras 12-4). The prohibition, moreover, went beyond what was necessary to encourage long-term saving and to protect the consumer from excessive charges. As to the latter, banks could offer the consumer the choice between remuneration coupled with a service charge and a free account without service charge (para. 22).

\section{Ship registration}

In Commission v. Netherlands (ships), 2004 the requirements for ship registration came under scrutiny again. This time the case was about the requirements established by the Netherlands which mostly concerned the structure of the shipowning companies wanting to register a ship in the Netherlands. One the one hand, the Dutch ship registration scheme required shareholders and directors of a company to be nationals of a member state of the Community or of the European Economic Area, if the company wanted to register one of its ships in the Netherlands. On the other hand, the ship management scheme required directors to be such nationals and to have residence within the territory of the Community or the European Economic Area. The Court rejected both schemes for violating the freedom of establishment of companies. The restructuring of the companies concerned and the redefining of their recruitment policy, both necessitated by the Dutch requirements, as obstacles to the freedom of establishment were not justified by the need to control ships effectively and to exercise jurisdiction (para. 19). The nationality of the shareholders and directors and their residence was irrelevant for control purposes and the real link to the actual owner of a ship needed for such purposes could also be established through a place of business in the Netherlands which was managed on a day-to-day basis by a person with powers of representation (paras 21, 25-6, 32-7).

Ship registration was also at issue in Viking, 2007. The Finnish company that operated a ferry service between Helsinki and Tallinn intended to reflag its ship, the 'Rosella', to Estonia in order to escape the application of the collective agreements of Finland and employ Estonian seamen at lower wages. The Finnish union invoked union solidarity and obstructed the re-flagging of 'Rosella' through the international union umbrella association. That association resisted flags of convenience as a matter of policy. The Court decided that collective action measures taken by unions were not per se removed from the scope of the freedom of establishment (paras 35-7 and 47). In holding so, the Court in turn recognized a fundamental right to collective action (paras 43-4). In the case at 
hand, the unions' measures taken to ward off 'Rosella's' reflagging were subject to the freedom of establishment, although the unions were, technically speaking, private organizations (paras 57-66). The unions' measures amounted to a restriction of Viking's freedom of establishment which was exercised through the registration of a ship (paras 72-3). As far as the Finnish union's actions were concerned, they were in principle justified to protect Finnish workers if the national court found so and if a commitment offered by Viking not to make Finnish workers redundant did not prove effective in protecting their work and employment conditions (para. 82-7). However, the international union association's general policy to combat flags of convenience was not justified by the protection of workers, since the policy prevented re-flagging of ships even when the labour force was not at risk (paras 88-9).

\section{Taxation of groups}

In Marks \& Spencer, 2005 the Court again dealt with the taxation of groups. The United Kingdom refused group relief to parent companies established in the United Kingdom for losses incurred by subsidiaries in other member states, while it was granted for losses by domestic subsidiaries. Losses made abroad could therefore not be set-off against profits generated in the United Kingdom. While restricting the freedom of establishment by denying a cash advantage (para. 33), the British scheme was, according to the Court, justified by a combination of three grounds, namely the three needs to maintain a balanced allocation of the powers to impose taxes between the member states, to avoid that losses were taken into account twice, and to forestall tax avoidance. If it was not justified, parent companies could have avoided paying taxes by transferring losses within the group to the state that applied the highest tax rate to profits (paras 45-50). However, group relief had to be granted in one specific constellation, viz. when the possibilities to offset a loss in the state where the subsidiary was established were exhausted and it was impossible to offset the loss in the future, for instance because the subsidiary was sold (para. 55-6).

\section{Cross-border merger}

In Sevic Systems, 2005 the German authorities refused to register a cross-border merger between a German and a French company. According to the Court, such mergers were a particular method of exercising the freedom of establishment (paras 17-20). Not to register cross-border mergers, while purely national mergers were registered, constituted a difference in treatment which deterred from exercising the freedom of establishment (paras 21-3). While harmonisation could not be a precondition for establishment, a difference in treatment such as that was in principle susceptible of justification based on various grounds, such as the protection of minority shareholders, creditors, and employees, the effectiveness of fiscal supervision, or the fairness of commercial transactions. However, an downright refusal to register the merger went beyond what was necessary to safeguard those needs (paras 26-30). 


\section{Further companies, taxation (2006)}

In the year 2006, the Court dealt with a number of cases concerning establishment of companies. CLT-UFA, 2006 invalidated a distinction in Germany's tax law between branches and subsidiaries of foreign companies. The situations of a German branch and a German subsidiary of a company established in Luxembourg were comparable, given that the profits of branches and subsidiaries were treated equally under the double taxation convention (paras 23-30). Germany could therefore not lawfully apply a higher tax rate to the profits of branches than to those of subsidiaries in Germany, else the free choice under the freedom of establishment between branches and subsidiaries would be impaired and disadvantageous treatment would result (paras 15-7). In Keller Holding, 2006 the Court was seized with a dispute about dividends again. The Court again invalidated a difference in treatment established by German tax law in comparable situations. The cost associated with dividends paid was deductible for a German parent company in the case of domestic indirect subsidiaries, but not so in the case of indirect subsidiaries in Austria, although in both cases dividends paid were in reality not subject to tax in Germany (paras 31-4 and 37). That difference in treatment violated the freedom of establishment under the Treaty and the European Economic Area, for neither the need to maintain the coherence of the tax system nor the territoriality principle justified it (paras 43-4).

Cadbury Schweppes, 2006 addressed the tax scheme of the United Kingdom which aimed to counteract low tax rates in other states. In essence, the United Kingdom levied a tax on the profits of a foreign subsidiary in the hands of the domestic parent company, if the tax rate applied abroad to those profits was below a certain level, that was three quarters of the rate applicable in the United Kingdom in a similar situation. According to the Court, the difference in treatment based on whether a subsidiary was established abroad or not (paras 43-6) could only be justified by the need to combat abusive practices, viz. tax avoidance, if the exemptions from the British tax were properly interpreted so that only wholly artificial arrangements which did not reflect any genuine economic activity were targeted (para. 55). For that purpose, an objective element, namely no real economic activity in the 'host' state, and a subjective element, namely the intention to obtain a tax advantage, had to be proven to reflect tax avoidance (paras 61-70). In ACT Group, 2006 the Court again dealt with the United Kingdom's tax regime. The Court mainly determined that the situations of non-resident and resident shareholders were not comparable as regarded the tax treatment, by the member state where the distributing company was resident, of dividends distributed by that company (para. 57), else a member state would be required to forgo its right to tax profit generated in its territory. (Conversely, the situations were comparable when a resident shareholder received dividends from a resident and from a non-resident company, as regarded the tax legislation of the state where the recipient was resident. That was established in Lenz, 2004 and Manninen, 2004, two cases concerning the free movement of capital.) That 
ruling applied as long as the taxation of the profits of the resident company was at stake, but not when it came to the taxation of the income of shareholders. As regarded the latter, the situations of resident and non-resident shareholders were comparable again (para. 68). That latter point was confirmed shortly after ACT Group, 2006 in Denkavit, 2006 in which the Court consequently struck down a French withholding tax on dividends which applied almost exclusively when the dividends were distributed to foreign parent companies (paras 36-9). The reduction of that tax by the relevant double taxation convention between France and the Netherlands and the authorization in it to offset the French withholding tax could not overcome the restriction, as foreign-sourced dividends were exempt from taxation in the Netherlands. Thus, credit was not given in the Netherlands for tax withheld in France (paras 46-9).

FII Group, 2006 was handed down on the same day as ACT Group, 2006 and also dealt with British taxes in the context of dividends. FII Group, 2006 dealt with many aspects of the British system. Inter alia, the United Kingdom applied for foreign-sourced dividends a system of partial imputation regarding the corporation tax paid by a foreign company distributing dividends. For nationally-sourced dividends a system of exemption applied which had the effect that dividends were not taxed in the hands of the recipient due to tax credit. The Court basically did not find any issue with the freedom of establishment (paras 33-57 and 51-3), while it found some issues under the freedom of capital (see paras 61-71). However, the differences in the operation of the British advance corporation tax fell afoul of the freedom of establishment, essentially because companies receiving foreign-sourced dividends did not receive any credit for the British advance corporation tax (paras 79-98). The way surplus advance corporation tax was dealt with raised an issue only in a specific constellation, namely the surrender of surplus advance corporation tax (paras 113-134). However, the new foreign income dividend regime did not comply with the freedom of establishment or the freedom of capital (paras 140-173). Finally, in the year 2006, the Court in Innoventif, 2006 held that the freedom of establishment did not preclude national law from requiring all companies wanting to register branches to advance the administrative costs of the publication of the relevant articles of association, a publication which was in accordance with Eleventh Council Directive 89/666 (paras 37-42).

\section{More dividends case-law}

The dividend case-law then continued with Thin Cap, 2007. In this case the Court addressed the scheme established and repeatedly amended by the United Kingdom to counteract a practice known as thin capitalization. Within groups share capital was kept 'thin' and replaced by intra-group loans with the aim of paying interest rather than distributing dividends, thus steering clear of taxes due on dividends. The United Kingdom essentially responded to this practice by taxing such interest like dividends in so far as the loan went beyond what would have been agreed at arm's length. The Court found a restriction of the freedom 
of establishment in so far as the British practice treated interest as dividends even though the relevant loan had been granted at arm's length, notably when a loan had been granted intra-group by a company not established in the United Kingdom (paras 38-45 and 59-63). The resulting disadvantageous tax position was not justified by the balanced allocation of powers of taxation or the cohesion of the tax system, since the increased tax on interest in the United Kingdom was not mirrored by a decrease in tax liability in other member states based on double taxation conventions. Essentially, the British approach was based on a unilateral decision taken by the United Kingdom (paras 49-69). While the British approach to counter thin capitalization was designed to prevent tax avoidance as an abusive practice, the approach went beyond what was necessary in so far as it taxed, in cases of international intra-group loans, interest paid under market conditions. Moreover, even when a loan was agreed at more favourable terms than those available on the market, a group had to have the possibility to put forward, in a specific case, a commercial justification for the favourable terms of the loan (paras 76-91).

\section{Companies and third countries}

In Lasertec, 2007 a covert distribution of profits in Germany was at stake in a similar constellation as in Thin Cap, 2007. However, the Court held that the freedom of establishment could not be relied upon, because it was a company established in Switzerland, a third country, that had a definite influence through shareholdings in a German company (para. 27). In a similar vein, the Court in $A$ and $B, 2007$ held that the freedom of establishment could not be relied upon when a branch or a subsidiary in a non-member state was held by a company established in a member state. Thus, in a situation where a Swedish group had an establishment in Russia, the freedom of establishment could not be relied on to determine whether the salaries paid to employees of the Russian establishment had to be taken into account when assessing a Swedish legal threshold which depended on the total amount of salaries of employees. In both cases, Lasertec, 2007 and $A$ and B, 2007, the Court made it clear that it was the freedom of establishment, rather than the freedom of capital that was at issue. According to the Court, it was unnecessary to examine the freedom of capital, as any restriction of that freedom was the inevitable consequence of a restriction of the freedom of establishment (paras 25-7 of Lasertec, 2007 and paras 27-9 of $A$ and B, 2007). The Court reiterated in Holböck, 2007 that the freedom of establishment could not be invoked in situations involving third countries. Accordingly, the full taxation of dividends distributed by a Swiss company to a shareholder resident in Austria as income, while dividends distributed by an Austrian company would have been taxed at only half the rate, was not precluded by the freedom of establishment (para. 29). Even assuming that the free movement of capital applied, the Austrian distinction would not have been precluded, for it was a restriction of a movement of capital that in substance had existed already at the time when the Treaty had entered into force (paras 31-44). In Ergste, 2007 the Court con- 
firmed that line of authority by holding that the freedom of establishment could not be relied on to challenge Germany's refusal to allow profits to be offset by losses incurred by branches in the United States of America.

\section{Further group cases}

Rewe, 2007 also dealt with groups. The parent company of an international group established in Germany challenged the conditions to allow partial writedowns on subsidiaries established in other member states as losses. According to the Court, the possibility to write-down holdings in domestic subsidiaries immediately, while foreign subsidiaries could be written down only under certain conditions constituted a difference in treatment notably due to the cash-flow disadvantage (paras 28-35). That difference in treatment was not justified. None of the grounds put forward held water, neither a combination of the balanced allocation of the power to tax, the danger of losses being taken into account twice, and tax avoidance as in Marks \& Spencer, 2005 (paras 41-53) nor the effectiveness of fiscal supervision (paras 55-8), the coherence of the tax system (paras 60-67), or territoriality (paras 68-9). In contrast, the Marks \& Spencer, 2005ground(s) stood firm in $O y A A, 2007$. In case of intra-group transfers from a subsidiary 'upwards' Finland allowed the deduction of the financial transfers from the income of the subsidiary, though only if the receiving parent company was established in Finland. The Court found that the difference in treatment based on the place of establishment of the parent company (paras 31-43) was justified by the combination of the three grounds admitted in Marks \& Spencer, 2005 , namely the balanced allocation of the power to tax, the danger of losses being taken into account twice, and tax avoidance, while the first and the third ground were in the focus in Oy AA, 2007 (paras 53-65). The Court, in particular, held that a less restrictive alternative to the Finnish measure did not exist, although it was rather general and not particularly designed to counteract wholly artificial arrangements (para. 63). The Court further clarified that case-law in $\mathrm{Lidl}$, 2008. Germany had refused to allow the deduction of losses incurred by a permanent establishment in Luxembourg from income generated by the 'parent' limited partnership established in Germany. The Court found that the restriction of the freedom of establishment which consisted in discouraging the permanent establishment in other member states (paras 20-2 and 23-6) was justified by each of the two reasons of preserving a balanced allocation of powers of taxation and of forestalling that losses were taken into account twice (paras 31-7). The Court, in addition, made it clear that it was not required that each of the three reasons on which the justification in Marks \& Spencer, 2005 was based - more specifically the balanced allocation of powers to tax, the risk of losses being taken into account twice, and tax avoidance - was given. Instead, as already implied in $\mathrm{Oy}$ $A A, 2007$ a combination of two grounds was sufficient (paras 36-42). In contrast to Marks \& Spencer, 2005, moreover, the two conditions required by necessity, viz. the exhaustion of possibilities to offset and the impossibility to take 
into account a loss in the future, did not pose a problem in Lidl, 2008 (paras 49-51).

\section{Inheritance tax}

In Geurts, 2007, an exemption from inheritance tax was applicable in the Flemish region of Belgium, if the family company which was part of the estate employed a minimum number of workers in the Flemish region for a certain time. The Court ruled that the difference in treatment based on where the workers were employed constituted indirect discrimination (paras 18-23). Even if ensuring the survival of local companies and the maintenance of employment possibly constituted grounds of justification, it was not necessary to limit the exemption to companies that employed workers in the Flemish region. The effectiveness of fiscal supervision as a ground for justification was not plausible, either, although Directive 77/799 did not apply to inheritance tax (paras 26-8).

\section{Taxation of limited partnerships}

In Columbus, 2007 the partners of a limited partnership established in Belgium were resident in Germany. Since Belgium applied a tax rate to the profits of the partnership which was less than 30 per cent, Germany did not apply the double taxation convention which exempted profits made in Belgium from taxation in Germany, but instead the regular offset-method. Germany thus took into account the taxes paid in Belgium, but taxed the profits again as income up to the overall level to which such profits were normally taxed in Germany. Because of that method the tax burden of the partners increased by 53 per cent. The Court did not find a restriction of the freedom of establishment. Germany treated all partnerships alike, regardless of whether they were established in Germany or abroad, by applying the same tax rate. The Court did not have jurisdiction for possible violations of the double taxation convention. The choices made available by the freedom of establishment were not impeded, either (paras 39-54).

\section{More dividends}

In Lammers, 2008 the Court followed-up on the Thin Cap, 2007-case-law. Belgium's approach to re-classify as dividends payments made by a Belgian subsidiary on claims by a parent company established in another member state which was a director of the subsidiary, as soon as the total of loans exceeded the paid-up capital plus taxed reserves at the beginning of the taxable period, was qualified as a restriction of the freedom of establishment, since such re-classification was not applied when the parent was established in Belgium. The restriction was not justified, as it could not be excluded that interest paid pursuant to agreements entered into on an arm's length basis would be re-classified as dividends as well (paras 31-3).

\section{Currency loss}

Deutsche Shell, 2008 dealt with a currency loss on start-up capital injected in a permanent establishment in Italy. When the capital invested was reimbursed lat- 
er on to the German company Deutsche Shell, the German tax authorities refused to take into account the loss that had occurred due to the depreciation of the Lira in Deutsche Shell's corporation tax assessment. According to the Court, an obstacle with a deterrent effect on the establishment in other member states was inherent in the German tax approach which ignored the financial loss suffered (paras 29-32). That restriction was not justified by the coherence of the tax system, because no direct relationship existed between Deutsche Shell's currency losses and gains (para. 40). Moreover, by nature only Germany could take into account the currency losses incurred, because the capital was denominated in Lira. That was why the need for a balanced allocation of the powers to tax did not justify the restriction, either (para. 44).

\section{Expenses for research and development}

In Commission v. Spain (R\&D), 2008 companies' expenses for research and development were deductible to a larger extent when the investment had been made in Spain. The Court held that the freedom of establishment - and the freedom of services as far as subcontractors and centres of research were concerned - was restricted, because investments abroad by Spanish companies and investments in Spain by companies abroad, both by means of establishments, were deterred (paras 22-4). Justification was not available, as fiscal incentives with a view to investments in the member state concerned were not a ground for justification and as tax evasion was to be excluded by requiring proof from taxpayers and by means of cooperation under Directive 77/799 (paras 33-42).

\section{Further group taxation}

In Burda, 2008 a corrective tax mechanism applied by Germany was at issue. As a tax audit revealed, Burda, a German subsidiary of a Dutch and a German company, had distributed more funds than it had had taxable income. The German authorities then applied a corrective mechanism that in essence charged Burda's capital. However, only the German parent company received a corresponding tax credit in Germany, while the Dutch parent company did not. That treatment, according to the Court, did not constitute a restriction of the freedom of establishment, while Directive 90/435 did not preclude it, essentially because the subsidiary was charged irrespective of the seat of the parent company. Its tax burden was not altered according to whether it distributed its profits to a resident or a non-resident parent company (para. 83). It was up to the member state where the parent company had its seat to ensure that a tax credit for corporation tax paid in the member state where the subsidiary was established was granted and thus economic double taxation was excluded (para. 89-94).

In Bauer Verlag, 2008 a company established in Germany which was wholly owned by a German parent company held an unlisted holding in a limited partnership established in Spain. The German tax authorities assessed those holdings

in a different way than holdings held in a partnership established in Germany for the purpose of the wealth tax liability of the parent company. The former were 
taken into account on the basis of their net asset value to which prospective earnings were added, while for the latter the net asset value was relevant. According to the Court, the resulting tax disadvantage for the parent company had a dissuasive effect (paras 31-3) and was not justified by the cohesion of the tax system for lack of a direct link (para. 38). Furthermore, evidence supplied by taxpayers sufficed for fiscal supervision, even though Directive 77/779 was possibly not applicable in the case at issue (para. 41).

The judgment in Lidl, 2008 was further elaborated in Wannsee, 2008. In this case, in some contrast to Lidl, 2008, Germany had permitted a company established in Germany to take into account for the German tax assessment losses incurred by a permanent establishment in Austria in the years before 1994. As a result profits generated in and subject to taxation in Germany were essentially reduced. However, the German tax authorities reintegrated those losses when the establishment in Austria generated profits in the year 1994, by taxing those profit made in Austria, although they were subject to taxation in Austria, too and lawfully so pursuant to the relevant double taxation convention. Austria did not set of the losses incurred in Austria against the profits made in Austria, because the losses had already been taken into account in Germany in the assessment of the 'parent' company. As Austria was a member of the European Economic Area in 1994, the freedom of establishment as interpreted by the Court for the internal market applied uniformly (paras 23-6). According to the Court, a restriction of the freedom of establishment occurred because a tax disadvantage resulted when Germany withdrew the previous taking into account of the losses by factoring in the profits generated by the permanent establishment in Austria (paras 32-8). However, the need to maintain the coherence of the German tax system justified the restriction, because Germany's assessment of profits made in Austria mirrored the previous factoring in of losses made in Austria, in other words, there was a direct personal and material link between the treatment of the losses and the profits, the 'reintegration being the logical complement of the deduction previously granted' (para. 42). Due to this symmetry the restriction was justified (paras 42-5). That the German company was by law unable to have the losses incurred in Austria taken into account by the Austrian tax authorities to set them off against the profits generated in Austria was irrelevant, for Germany was not required to adapt its tax system to the particularities of the Austrian tax system (paras 47-52).

France offered an integration regime for consolidated taxation of groups which was at stake in Papillon, 2008. Its application was refused to a parent company established in France as far as its sub-subsidiary in France was concerned by reason of a subsidiary being interposed which was established in the Netherlands (see para. 17). At issue thus was the refusal to apply the tax integration regime to the French parent company given that an interposed subsidiary was established abroad. As losses could not lawfully be taken into account immediately, the refusal to apply the integration regime when a foreign subsidiary was interposed constituted a restriction of the freedom of establishment (paras 
18-22). Since the aim of the regime was consolidation and that aim was not necessarily jeopardized when the integration regime was extended to cover situations where an interposed subsidiary was established abroad, groups that did not have an interposed subsidiary were comparable to groups that had one (paras 25-30). France's refusal to apply tax integration was, however, covered by the need to maintain the coherence of the tax system, though not by the balanced allocation of powers of taxation, as taxation in only one member state was at issue (paras 36-40). The mechanism of neutralisation of transactions applicable in the integration regime did not apply in the case of an interposed foreign subsidiary. A risk arose that losses would be taken into account twice, in France and in the Netherlands, in the case of Papillon. In such a case, a parent company would benefit from the advantage, namely tax integration, while it eschewed the disadvantage, viz. neutralisation of intra-group transactions, which would upset the coherence of the system (paras 45-51). Yet the outright refusal to apply tax integration went beyond what was necessary. Quite apart from information provided under Directive 77/799, a parent company also had to be given the possibility to prove that the risk of profits being taken into account twice was inexistent in a specific case (paras 55-61).

Truck Center, 2008 concerned a withholding tax Belgium charged on interest payable by a resident company to a non-resident company based on a loan agreement. Such withholding tax was not due when a loan had been agreed between two resident companies. While the procedures for the charging of tax differed according to whether a company was resident in Belgium or not (para. 34), the situations of resident and non-resident recipient companies were, however, not comparable, according to the Court. The Belgian state was involved in two different capacities, namely as the state where two companies were resident and as the state in which interest originated. In the case of a non-resident recipient company withholding tax applied. In the case of a resident recipient company withholding tax did not apply; instead, the recipient company was subject to corporation tax in Belgium, a tax to which the interest paid was subject as any other income. The non-resident recipient company was not necessarily worse off, either, as withholding tax was usually lower than corporation tax. Belgium and Luxembourg - the other state involved in the case - had, in addition, agreed in the double taxation convention that each state was at liberty to charge a withholding tax. Finally, the situations for the recovery of the sums due differed (paras 41-9).

With Commission v. Greece (dividends), 2009 the Commission challenged two elements of Greece's tax system. The Court confirmed that it violated the freedom of establishment and the freedom of capital to subject foreign-sourced dividends to a heavier tax burden than nationally-sourced dividends. In Greece, the latter were exempt from income tax at the level of the shareholder in the light of the Greek corporation tax paid, while the former were not (paras 24-8). Moreover, the higher tax rate Greece applied to foreign partnerships as com- 
pared to domestic partnerships unlawfully dissuaded partnerships established in other member states from operating an establishment in Greece (paras 38-42).

In Aberdeen Alpha, 2009 the Court dealt with Finland's charging of withholding tax on dividends paid by a Finnish subsidiary company to a parent shareholder established in Luxembourg, while if the parent shareholder had been established in Finland withholding tax would not have been due. In the case at hand, Directive 90/435 did not apply, because the recipient company, which was to hold all the shares in the Finnish company concerned, was established in a special form in Luxembourg, namely an open-ended investment company called SICAV, and was only subject in Luxembourg to a tax on capital at a rate of 0.01 per cent. The Court reiterated that the positions of foreign and domestic shareholders became comparable by reason of Finland's exercising its income tax jurisdiction over dividends by means of a withholding tax (para. 43). Even if the Luxembourg company were exempt from income tax in Luxembourg, the series of charges to which Finnish dividends paid to shareholders abroad were subject entailed a restriction (paras 39-55) which was not justified by the grounds argued - namely neither by the prevention of tax avoidance, because the Finnish measure did not exclusively target wholly artificial arrangements (para. 65), nor the need for a balanced allocation of powers of taxation, essentially since Finland itself decided not to tax resident shareholders on such income (paras 67-70), nor the coherence of the tax system, as the exemption from withholding tax was not subject to the taxation of the dividend in the hands of the resident shareholder (para. 73).

In KBC Bank, 2009 the Court decided that Belgium's tax law could lawfully distinguish between subsidiaries and permanent establishments by limiting the possibility to deduct profits distributed by a subsidiary to the extent of the profits of the parent company during the taxable period concerned, provided that there was not any discrimination between subsidiaries in Belgium and those abroad or between permanent establishments in Belgium and those abroad (para. 81). (The Court also ruled on questions relating to the freedom of capital and Directive 90/435 on the taxation of groups in this judgment.) In Gaz de France, 2009 the Court inter alia ruled that the Community legislature had not restricted the freedom of establishment or the freedom of capital by not including the French société par actions simplifié within the scope of Directive 90/435 (para. 61).

\section{Moving the seat}

Cartesio, 2008 dealt with a Hungarian company which wanted to move its seat to Italy while remaining subject to Hungarian law. The Hungarian authorities refused registration on the ground that in Hungary the real seat approach was applicable. Accordingly, the company concerned would have been forced to wind down and re-establish itself in Italy. The Court did not find a restriction of the freedom of establishment in Hungary's refusal. Companies were creatures of national law pursuant to Daily Mail, 1988 and the national law of each member 
state chose between the various connecting factors possible, i. e. the registered office, the central administration, or principal place of business, to determine whether a company came into existence according to its own law. Only after that choice had been made and applied in a specific case and a company had come into being, could that company then rely on the freedom of establishment. Thus, the freedom of establishment, or secondary legislation, did not govern the transfer of the real seat or the registered office from one member state to another, while the company maintained the personality under the first state. Rather, future Community legislation would have to address the question. In contrast, the freedom of establishment applied when a company wished to become subject to the law of another member state (paras 100-14).

\section{Secondary law re companies}

In the 2000s, the Court also interpreted the secondary law concerning the freedom of establishment of companies in a series of judgments. Diamantis, 2000 and Commission v. Spain, 2008 took on the Second Council Directive 77/91, as did Audiolux, 2009. BIAO, 2003 dealt with the Fourth Council Directive 78/660. Springer, 2004 concerned Directive 90/605, which had amended Directives $78 / 660$ and $83 / 349$, and its validity in the light of the fundamental right to exercise a trade or profession and the freedom of the press. Markopoulos, 2004 was about the Eighth Council Directive 84/253 and, in part, about the Vlassopoulou, 1991-line of authority in the context of that Directive. Berlusconi, 2005 dealt with the First, Fourth, and Seventh Council Directive, i. e. Directives $68 / 151,78 / 660$, and 83/349, respectively, and the lex mitior principle as a fundamental right in the context of the implementation of a Directive. In Berlusconi, 2005 the questions asked later on in Mulliez, 2006 had already been answered. Moreover, Epikouriko Kefalaio, 2004 dealt with Directives 73/239 and 79/267 on direct insurance. Ntionik, 2007 concerned Directive 2000/34 on stock exchange listings.

\section{Diploma recognition in 2000-2002}

Hocsman, 2000 initiated the diploma recognition case-law of the 2000s. The Court decided that the Vlassopoulou, 1991-line of authority also applied when a Directive, while regulating the specific profession at issue, was not applicable. According to the Court, the scope of Vlassopoulou, 1991 was not to be reduced by a Directive (para. 31). In the case at issue, a general diploma in medicine had been awarded in a third state, namely Argentina. It was later on recognized as equivalent in Spain. That allowed the person concerned to obtain the specialization in urology in Spain. While France was not obliged to recognize the specialization based on Directive 93/16 on doctors, since the general diploma had been awarded in Argentina, France was required, according to the Court, to apply the Vlassopoulou, 1991-comparison (paras 32-6).

Erpelding, 2000 further elaborated on Directive 93/16. The Court decided that the use of the title 'specialist doctor' in the language and according to the 
nomenclature of the host state was the necessary corollary of the automatic and compulsory mutual recognition under Directive 93/16, if it applied (paras 23-7). On a more technical note the Court also interpreted the right to use the 'home' state title and the possibility for the host state to authorize the use of the title in a language other than that of the 'home' state under article 10(1) of the Directive (paras 31-2).

In Dreessen II, 2002 the Court confirmed the approach taken in Hocsman, 2000 and clarified that the Vlassopoulou, 1991-line of authority applied regardless of the reason why a directive in a specific field was not applicable, be it that a diploma had been obtained in a third country as in Hocsman, 2000 or that a diploma in a specific profession was not covered as in Dreessen, 1994 with an engineer diploma under Directive 85/384 on architects (para. 28). Commission $v$. Spain (doctors), 2002 again confirmed that approach. Spain was not allowed systematically to require doctors who had followed specialist training in other member states but did not benefit from automatic recognition under Directive 93/16 to sit the same state examination as Spanish doctors in order to begin specialist training, else the Vlassopoulou, 1991-case-law would be disregarded (paras 37-40). A second complaint by the Commission under Directive 93/16 challenging registration as a condition for reimbursement by the Spanish health system was, moreover, rejected (paras 46-56.)

In Gozza, 2000 the Court reiterated the ruling given in Carbonari, 1999 and extended it to the adequate remuneration in case of part-time training in specialised medicine (paras 41-4). In Commission v. Spain (architects), 2000 the Court held that Spain had failed to implement Directive 85/384 on architects by limiting the occupation of migrant architects benefitting from mutual recognition under that Directive to the activities they were allowed to pursue under 'home' state legislation. According to the Court, if mutual recognition applied pursuant to the Directive, the architects benefitting from it had to be allowed to pursue the same activities as architects holding the host state title (paras 35-40). Moreover, the Court held that recourse to the derogation clause in article 56 Treaty was no longer possible once directives had achieved harmonisation (para. 42; the Court had previously ruled so for derogations from the free movement of goods). In a similar vein, Commission v. Italy (architects), 2002 confirmed that Italy's implementation of Directive 85/384 was improper in several regards. Italy had (i) failed to include some German diploma in the list of diplomas benefitting from automatic recognition (paras 21-4) and to clearly state which diplomas benefitted from automatic recognition (paras 30-1). Italy had (ii) violated the freedom of establishment and services by consistently requiring submission of the original diploma or a certified copy for recognition (paras 37-40) and of a certificate of nationality as well as certified translations of all documents (paras 45-6). Italy had (iii) set the wrong reference date to apply the transitional arrangement (paras 51-3). Italy had (iv) violated the freedom of services by prohibiting architects who merely provided services and were thus not permanently established in Italy from having some infrastructure in Italy (paras 56-7) and by 
requiring those architects to follow an overly cumbersome registration procedure before the end of which services could not lawfully be provided (paras 62-5). Similarly, Greece had failed to implement Directive 85/384 properly, according to the Court in Commission v. Greece (architects), 2004. The Greek authorities unlawfully required migrant architects to submit a certificate attesting that their diploma benefitted from recognition (paras 19-21). They also took too long to deal with migrant architects' requests to be registered (paras 29-35), a failure that could not be justified, as Greece had argued, by the frequency of earthquakes in Greece (para. 33).

In Commission v. France (psychologists), 2001 France admitted not having properly transposed Directive $89 / 48$ on general diploma recognition with regard to psychologists, a regulated profession in France. Commission v. Italy (doctors), 2001 concerned the Italian scheme for dentists. The Court held that Italy had failed to implement Directive 78/687 on the coordination of dentists' activities, as Italy had established a second training track for dentists which combined general medicine with a specialisation in dentistry, in stark contrast to the unadulterated five years of dental training in accordance with the Directive (paras 37-40). However, according to the Court, Italy's transitional regime was in keeping with the Directive in that it enabled dentists subject to that regime - and exclusively those dentists - to be registered at the same time as ordinary doctors as well as dentists (paras 48-55).

In Commission v. Italy (ski-monitors), 2002 the Court confirmed that Italy had failed to live up to Directive 92/51 on a second system for recognition by applying a reciprocity requirement to diplomas of ski-monitors. Paracelsus, 2002 concerned lay medical practitioners (Heilpraktiker). Paracelsus was a school established in Germany offering training courses to become a lay medical practitioner. Parts of those courses were offered in Austria where the courses were also advertised. However, in Austria the activities of lay medical practitioners were reserved for doctors. Applying the case-law delivered under Directive 89/48, i. e. Aranitis, 1996 and De Bobadilla, 1999, the Court found that the profession of lay medical practitioner was not 'regulated' within the meaning of Directive 92/51 merely due to the fact that Austria reserved the corresponding activities to doctors (paras 31-6). The Austrian reservation - essentially a prohibition of the profession of lay medical practitioner - amounted to a restriction of the freedom of establishment and services. Yet, that restriction passed the Gebhard, 1995test, in particular since member states were entitled to decide on the level of public health protection required (paras 39-50). Similarly, Austria could lawfully prohibit that parts of the training took place in Austria given the need to ensure the efficacy of the prohibition of the profession (para. 61), but only in as far as 'confusion in the minds of the public' (para. 65) was created. Conversely, Austria had to permit advertising of the school's services in Germany, provided that it clearly stated that the profession could not be exercised in Austria (para. 68).

Klett, 2002 dealt with diploma recognition in the context of the Act of Accession of Austria. The Court ordered that an amendment to Directive 78/686 on 
dentists which had been introduced when Austria acceded to the Community did not violate the Treaty, since it was based on the Act of Accession which itself belonged to primary law. Austria, consequently, was not obliged to open a postdoctoral course for the training of doctors to become dentists to doctors holding doctoral degrees from universities in other member states, since the course was to be abolished progressively under the regime of Directive 78/686 and was only maintained temporarily to allow participants to finish their studies (paras 30-41).

\section{Diploma recognition in 2003-2004}

In Tennah-Durez, 2003 the Court dealt with the automatic recognition of diplomas under Directive 93/16 on doctors. After having explained that that Directive was different from Directives $89 / 48$ and $92 / 51$ in that it harmonized the educational system for doctors (paras 29-34), the Court decided that, as long as a doctor diploma - a 'doctor's passport' (para. 57) - had been awarded in a member state, Directive 93/16 made recognition mandatory, even if parts of the training had been followed in a third country and the member state awarding the diploma had then recognized that training as equivalent. In other words, Directive 93/16 did not contain a requirement as to a minimum duration of training in a member state, in contrast to Directives $89 / 48$ and $92 / 51$. As a consequence, France had to recognize a diploma awarded by a Belgian university after seven years of medical training, six of which had been followed in Algeria (paras 49-69). France was, moreover, bound by a certificate issued by Belgium attesting that training pursuant to Directive 93/16 had been completed (paras 75-80).

In Vogel, 2003 the Court ordered Germany not to permit doctors in general to practise dentistry, else an additional category of dental practitioners in violation of Directives 78/686 and 78/687 would be created. The title under which such doctors were allowed to practise dentistry in Germany was, according to the Court, irrelevant (paras 25-31). Rinke, 2003 must also be mentioned in this context, although the case was not strictly about diploma recognition. In this case, a doctor challenged under the fundamental right to equal treatment of sexes the requirement for doctors to have worked for at least six months full-time to qualify for residence, which arose from a combination of a Directive 93/16 on doctors and German law. The Court agreed that there was unequal treatment between women and men for statistical data proved it (para. 35). However, fulltime work for six months was an appropriate and reasonable requirement to ensure that doctors acquired the necessary experience and followed the evolution of certain pathological conditions. Neither Directive 93/16 nor the implementing legislation, in consequence, violated the fundamental right.

Morgenbesser, 2003 dealt with the registration of trainees which was required in Italy to be admitted for the bar exam. The Italian authorities refused to register Ms Morgenbesser as a practicante (trainee) on the ground that she held a diploma from a French rather than an Italian university. Directive 98/5 on lawyers did not apply, as she had not yet been admitted to a bar in a member 
state, neither did Directive 89/48, as the traineeship required to be admitted to the Italian bar could not be considered a regulated profession separate from the lawyer's profession (paras 44-55). As a consequence, the Vlassopoulou, 1991line of authority only forced the Italian authorities to make the comparison of qualifications (paras 57-71).

Burbaud, 2003, a case that also concerned the free movement of workers (see above), dealt with the French way of recruiting hospital administrators. That way combined recruitment with training in a school and based on that, ultimately, provided access to civil service. Ms Burbaud had acquired the qualification needed to become hospital administrator in Portugal, but her application to be recruited in France was rejected. The Court held that public service as such was not removed from the scope of Directive $89 / 48$ on a general system of recognition, save when article 48(4) Treaty or a particular directive applied (para. 39). Applying standard case-law on the 'regulated profession', a Community term (para. 43), the Court decided that passing the French system was equal to obtaining a diploma within the meaning of Directive 89/48, although a formal document was usually not issued (paras 44-53). It was up to the national court to decide whether the qualification Ms Burbaud obtained in Portugal was a diploma as well, and if so, to assess equivalence under the Directive (paras 54-7).

Beuttenmüller, 2004 was about acquired rights under Directive 89/48 on general recognition. According to the Court, Ms Beuttenmüller was entitled to rely directly on that Directive in order to set aside the practice of a German Land that required teachers to have passed three years of training under any circumstances or that training to have had a particular content (paras 51-2). Her teacher diploma, awarded after two years of training in Austria only, had been certified by Austria as equivalent to the current regular educational track taking three years to complete. She thus benefitted from an established right under the Directive (paras 40-4). In addition, the Court ruled that the four years of training required in the exception in article 3 Directive $92 / 51$ on a second system of recognition - an article that applied only in the event that article 3 Directive 89/48 was not applicable (para. 60) - was not to be understood so as to include probationary practice of teachers following after training (para. 64).

Fascicolo, 2004 was also about acquired rights, though those of doctors under Directive 93/16. The Court, in essence, sanctioned the Italian system of awarding posts as general medical practitioners. According to the Court, that system in distinguishing to some extent between doctors having obtained the right to practice general medicine before 31 December 1994 and those having obtained that right after that point in time, i. e. under the regime set up in accordance with Directive 93/16, was covered by the discretion afforded to the member states, since the Directive only required safeguarding the rights of doctors who had made use of the freedom of establishment before 1 January 1995 (para. 30). For completeness, the Court in Mosconi, 2004 declined to deal with the exclusion of an Italian civil engineer holding an Italian diploma from certain works 
on classified heritage buildings under Directive 85/384 on architects, because the situation was purely internal to Italy.

\section{Diploma recognition in 2005-2006}

Peros, 2005 confirmed Beuttenmüller, 2004 in that article 3(a) Directive 89/48 on a general system for recognition was directly applicable, since Greece had failed to transpose the Directive in time. It was so even though Greece had not designated the competent authorities pursuant to article 9(1) of that Directive. Aslanidou, 2005 was delivered on the same day as Peros, 2005 and ruled in the very same terms for article 3(a) Directive 92/51 on a second general system for recognition. (Peros, 2005 had concerned a mechanical engineer, Aslanidou, 2005 an occupational therapist.)

Commission v. Austria (dentists), 2005 again dealt with Directives 78/686 and $78 / 687$ on dental practitioners. According to the Court, Austria breached those Directives by allowing dentists (Dentisten) to pursue the profession of dental practitioner under the title Zahnarzt (dental practitioner), although they had not followed any university training and thus failed to fulfil the requirements of the Directives (paras 25-7). Moreover, Austria was wrong to apply article 19b Directive 78/686 to those dentists (paras 29-30). In contrast, Austria was right to authorize the remaining medical specialists in dental surgery, a profession Austria had abolished to implement the Directives, to choose between the titles of 'medical specialist in dental surgery' (Facharzt für Zahn-, Mund- und Kieferheilkunde) and 'dental practitioner' (Zahnarzt). The Directives did not impose on those medical specialists the obligation to bear the title 'dental practitioner'. Austria had not created an additional category of dental practitioners but implemented article 19b Directive 78/686 properly (paras 35-42).

Colegio, 2006 concerned the problem of partial recognition of a professional qualification. Is it possible to recognize a qualification only partially when a qualification allowed the pursuit in the 'home' state of an activity which in the host state was part of a wider profession? Was it possible to take up a regulated profession partially? These questions were raised with $\mathrm{Mr}$ Imo who held an Italian diploma of civil engineering with a specialization in hydraulics and required recognition in Spain where only a more general category of engineering existed. The Court decided that Directive 89/48 on a general system for recognition did not as such preclude partial recognition in the sense that the activities allowed in the host state could be limited to those permitted in the 'home' state; indeed partial recognition was possibly more in keeping with the freedom of movement, in particular when the compensatory measures to be imposed in the light of the difference between two professions were such that they, in fact, prevented the person from making use of the freedom (paras 17-25). Yet a distinction was to be drawn, because not to allow the partial taking-up of a profession amounted to a hindrance of free movement (paras 31 and 33), namely between (i) situations in which compensatory measures needed to be applied, for two professions were so similar that they both came within 'the profession in question' pursuant 
to article 3(a) Directive 89/48 (para. 34) and (ii) situations not covered by the Directive, because the differences were so significant that full and fresh educational training would have been required to establish equivalence (para. 35). In the latter case, if the activity in question could objectively be separated, partial recognition needed to be granted in combination with the obligation to bear the original 'home' state title together with a translation. That measure sufficed not to confuse consumers (paras 36-8).

In Commission v. France (diploma), 2006, Commission v. Austria (diploma), 2006, and Commission v. Germany (diploma), 2006 the Court formally confirmed that the member states concerned had failed to transpose Directive 2001/19 amending several diploma directives in time - a fact which they essentially did not dispute. In Sam Mc Cauley, 2006 the Court decided that the recognition of diplomas in pharmacy was only partially harmonised by article 2 Directive $85 / 433$, making automatic recognition mandatory only with regard to pharmacies that had been open for more than three years, i. e. not with regard to 'new' pharmacies, while leaving the member states the option to go further. As far as 'old' pharmacies were concerned, though, the member states did not have any discretion. Whether to proceed in steps in such a way, by means of partial harmonisation, was up to the Community legislature to decide (paras 25-32).

In Price, 2006 the Court first delimited the scopes of Directives 89/48 and $92 / 51$ and then decided that the profession of director of voluntary sales of chattels by public auction in France, seemingly in contrast to the situation in the United Kingdom, was a regulated profession for the exercise of which precise knowledge of national law was necessary, since French law required the person concerned to have passed substantive legal educational training. If the national court found that such directors in addition regularly provided advice or assistance in matters of national law - which was possible, for such advice was not just given in the traditional legal profession - possibly in a specialised area (paras 58-9), the choice of compensatory measures, viz. an adaptation period or an aptitude test, could be taken by the state rather than the individual concerned pursuant to article 4(1) third subparagraph Directive 89/48.

\section{Diploma recognition in 2007-2009}

In Commission v. Czech Republic (diploma I), 2007 and Commission v. Czech Republic (diploma II), 2007 the Court formally confirmed that the Czech Republic had failed to transpose in time Directive 93/16 on doctors and parts of Directive 78/686 on dental practitioners, respectively. Commission $v$. Portugal (architects), 2007 confirmed that the recognition of professional qualifications of architects was automatic under Directive 85/384. Hence, Portugal could not lawfully require migrant architects who were not registered with the order of architects in the 'home' state to take the regular exam to be passed for admission to the Portuguese order of architects (para. 28).

Commission v. Spain (hospital pharmacists), 2008 established that Directive $89 / 48$ on a general system for recognition was applicable in Spain to the regulat- 
ed profession of hospital pharmacist which was a specialisation of the profession of pharmacist in general. Neither the existence of Directives 85/432 and 85/433 on pharmacists, which applied only to the profession of pharmacist and not to specialisations of pharmacists, nor article 47(3) Treaty as such precluded Directive 89/48 from applying. As a consequence, Spain had to provide the option for nationals of other member states with equivalent qualifications to take up the profession of hospital pharmacist within the limits of Directive 89/48 (paras 36-43). In Commission v. Portugal (pharmacists), 2008 this approach was confirmed for the profession of pharmacist specialized in medical biology which was regulated in Portugal.

In Commission v. Greece (doctors), 2008 the Court held that Greece had failed to transpose Directive 93/16 on doctors, because Greece had recognized certain doctors with acquired rights protected by article 36 Directive 93/16 as holding the specialisation of general medical practitioner, although they had not followed the training required by articles 30 and 31 Directive 93/16 (paras 11-4). In Commission v. Spain (air traffic controller), 2008 the Court affirmed that the profession of air traffic controller was regulated in Spain within the meaning of Directives 89/48 and 92/51 on general recognition. Neither the fact that a set of qualifications was needed to be allowed to exercise the profession (paras 34-47) nor the fact that Directive 2006/23 on an air traffic controller licence had been adopted (paras 48-51) had any impact on that assessment for the time before Directive 2006/23 became applicable. Since recognition was not automatic under Directives 89/48 and 92/51, any particularities of the Spanish qualification could be factored into by way of compensatory measures (paras 52-6).

In Commission v. Greece (diploma), 2008 the educational regime that worked on the basis of so-called homologation agreements was mainly at stake. Under that regime training provided in one member state by private institutions led to the award of a diploma under the educational system of another member state based on a homologation agreement. Greece refused to recognize such diplomas on the basis of Directive 89/48 on a general system of recognition, claiming that higher educational training was reserved in Greece to public institutions, notably Greek universities. The Court rejected that line of argument, holding that nothing in Directive 89/48 indicated that a member state could treat diplomas awarded in another member state differently on the basis of where in the Community the training had been provided (paras 28-35). Diplomas were not recognized owing to their intrinsic value, but because they granted access to a specific profession (para. 29). The Directive had established a system of mutual trust based on a presumption of equivalence of qualifications in which it was the task of the authorities issuing diplomas to examine whether the conditions for their award were met (para. 30). Greece thus had to recognize such diplomas issued in other member states, even if the training provided on Greek territory was not recognized as higher education in Greece (para. 35). Furthermore, the Court acceded to a number of claims made by the Commission, namely that Greece had not re- 
spected that the choice of compensatory measures under Directive 89/48 had to be with the holder of a diploma, rather than the state (para. 44); that a certain Greek body was not entitled to verify facts established by diplomas to be recognized (para. 48); and that the law had to be unambiguous as to the re-classification of holders of equivalent diplomas in the Greek public service who had been wrongly classified (paras 50-9). Finally, the Court rejected a further challenge by the Commission, as it incorrectly categorized the Greek technical chamber (paras 71-5). In the judgment Commission v. Spain (diploma), 2008 of the same day the Court ruled in the same way as in Commission v. Greece (diploma), 2008. Spain had essentially refused to recognize diplomas in engineering awarded in Italy by an Italian university. The training had been pursued entirely at a university in Spain which had awarded a diploma that did not give access to the profession of engineer in Spain. Based on an agreement with the Italian university, the persons concerned took an exam in Italy and were awarded the Italian diploma of engineer (paras 43-4). The Court decided in the same way as in Commission v. Greece (diploma), 2008 that Spain had to recognize such diplomas subject to potential compensatory measures, irrespective of the fact that all training had been provided in Spain. The Court, in addition, rejected the arguments advanced by Spain that the situation was purely internal to Spain (para. 67) and that Spanish law was fraudulently circumvented (paras 72-3). Finally, the Court emphasized that, once such diplomas were recognized, the holders had to have the same promotion possibilities as those having the equivalent national qualification, irrespective of the shorter duration of training (para. 80). Kastrinaki, 2008 in (paras 50-2) confirmed the two judgments in Commission v. Greece (diploma), 2008 and Commission v. Spain (diploma), 2008. Khatzithanasis, 2008 and Commission v. Greece (diploma II), 2008, both of the same day, transposed this line of authority to Directive 92/51 on a second general system for recognition (para. 33 and para. 28, respectively). Commission v. Greece (diploma II), 2008, moreover, established that recognition of a diploma under Directive 92/51 could not lawfully depend on the 'home' state's answering of certain questions posed by the host state (paras 35-7). Cavallera, 2009 then established the limits of that case-law. In that case, Mr Cavallera, although having obtained a junior engineer diploma from a university in Italy, did not gain access to the profession of engineer in Italy for lack of having passed the Italian state examination. The certificate of homologation he obtained in Spain, which was granted solely on the basis of the Italian diploma and without any further education or examination, and the registration on the relevant register in Spain entitled Mr Cavallera to pursue the profession of engineer in Spain. However, according to the Court, he was not allowed to rely on Directive $89 / 48$ to obtain registration as an engineer in Italy on the basis of the Spanish certificate of homologation, else he would be able to take up the profession of engineer in Italy without having passed the prerequisite Italian state examination. This was so in particular because the Spanish certificate was awarded without further ado and thus did not provide evidence of any further qualification (paras 56-7). 
In Pesla, 2009 the Court then followed-up on the Vlassopoulou, 1991 line of authority for lawyers. The Court held that, in the comparative examination required by articles 39 and 43 Treaty (para. 38) and when determining the corresponding measures to be imposed to ensure that qualifications were equivalent, a member state was entitled to require knowledge of the law of its own legal system rather than of the law in general. Evidence of a comparable level of training in law was not sufficient. Thus, a person who had not taken the first state examination in Germany, but held degrees based on educational training in Polish and German law, need not have been admitted for a traineeship in Germany - a traineeship which was required to be admitted to the second state examination in Germany - without providing further evidence of qualification (paras 44-8). While partial recognition within the sense of the Vlassopoulou, 1991-line of authority was sufficient to guarantee the freedom of movement, it had to be a real, not merely a notional option. However, a member state was not required under articles 39 and 43 Treaty to lower the level of knowledge required for nationals of other member states, while it was free to do so (paras 50-64). Rubino, 2009, finally, applied Directive 2005/36 on the recognition of professional qualifications which replaced Directives $89 / 48$ and $92 / 51$ on general recognition. According to the Court, the fact that a temporary list of candidates successful in a selection procedure was established in Italy from which, later on, university lecturers were recruited did not imply that the profession of university lecturer became a regulated profession within the meaning of Directive 2005/36 under which the case-law established under Directives 89/48 and 92/51 concerning the term 'regulated profession' continued to apply (paras 23, 27 and 29-32). Selection and recruitment procedures to fill posts were not concerned by those Directives (para. 27). Consequently, Mr Rubino who had acquired a qualification as a lecturer in Germany - the 'facultas' and 'venia legendi', i. e. something called a Habilitation in Germany - need not have been exempted from the selection procedure in Italy. However, the qualification had to be taken into account duly in this procedure (para. 34).

\section{Social security}

\section{Scope and definitions}

In the 2000s, the Court clarified the scope of Regulation 1408/71 in several cases. In Movrin, 2000, the Court categorized a subsidy to sickness insurance contributions which Germany paid to recipients of old-age pensions as an old-age cash benefit according to article 1(t) Regulation 1408/71. The supplement aimed at alleviating the cost of sickness insurance for pensioners and was paid directly to the sickness insurance institution. As its amount indirectly depended on the amount of the pension and was paid exclusively to pensioners by the pension insurance institution, it was an old age rather than a sickness benefit (para. 40). As 
such it was not be made subject to a residence requirement pursuant to article 10(1) Regulation 1408/71. Even if sickness insurance contributions had been generally lower in the Netherlands, Germany would have had to grant the subsidy (para. 51). In Offermanns, 2001 the Court addressed Austria's stepping in when a parent failed to make maintenance payments owed to a child of whom the other parent had custody. Austria was subrogated into the claim, when it advanced the payments due. The Court classed that support as a family benefit under articles $1(\mathrm{u})$ and 4(1)(h) Regulation 1408/71, because it helped a family to meet expenses incurred due to the maintenance of the family. It was a public contribution to a family's budget to alleviate the financial burdens involved in the maintenance of children (para. 41). From the perspective of the recipient the benefit was not provisional (para. 44). The Court moreover confirmed that the derived-rights approach did not apply anymore to family benefits. The children of a self-employed worker were therefore covered by Regulation 1408/71 as far as family benefits were concerned (para. 34-5). Hence, the benefit had to be provided to nationals of member states other than Austria on an equal footing. Laurin Effing, 2005 confirmed that the maintenance payments advanced by Austria constituted a family benefit. That the person concerned served a prison sentence and that the payments were advanced for that reason did not have an impact on the assessment (para. 27). Moreover, a prisoner who was insured against the risk of unemployment was within the scope ratione personae of Regulation 1408/71 as he was insured against a risk it covered.

\section{Special non-contributory benefits}

With Jauch, 2001, the Court continued its case-law on special non-contributory benefits. Article 4(2a) Regulation 1408/71 had definitely brought such cash benefits within the ambit of the Regulation, because they addressed risks it typically covered, although only in a substitute, supplementary or ancillary way. Article 10a Regulation 1408/71, in turn, exempted such benefits from exportability, since they had some atypical properties which brought them close to social or medical assistance. The Court in Jauch, 2001 examined an Austrian care allowance. Although the care allowance was listed in annex IIa among the special non-contributory benefits, the Court proceeded to verify whether it was special and non-contributory (paras 19-22). It found that the allowance was not special - a point which had already been decided for the similar German care insurance benefits in Molenaar, 1998. It was granted objectively on the basis of a legally defined position and could not be likened to social assistance (paras 26-8 of Jauch, 2001). It was contributory, too, albeit only indirectly, since sickness insurance contributions had been raised in Austria to create the budgetary room to introduce the allowance (para. 33). As a regular sickness benefit it therefore had to be granted to persons resident abroad.

Leclere, 2001 concerned several benefits provided by Luxembourg law in case of child birth to those who resided in Luxembourg. The applicants claimed that the provisions of Regulation 1408/71 which had the effect of sanctioning those 
residence requirements were contrary to articles 48 to 51 Treaty. The exclusion from the scope of Regulation 1408/71 of certain childbirth and adoption allowances, including the Luxembourg childbirth and antenatal allowances, in article $1(\mathrm{u})(\mathrm{i})$ was, so the Court, in accordance with the Treaty, since a restriction of the scope of the Regulation itself did not add further disparities to those resulting from the lack of harmonization (para. 29). In contrast, while article 10a Regulation 1408/71 validly sanctioned residence requirements for special noncontributory benefits, the Luxembourg maternity allowance could not lawfully be made subject to a residence requirement. It came within the scope of Regulation 1408/71, but was not 'special' within the meaning of article 4(2a). It was part of the general legislation addressing one of the risks covered by Regulation $1408 / 71$ and was available to every woman giving birth to a child. Thus, annex IIa, in so far as it listed the benefit, was incompatible with articles 48 to 51 Treaty (paras 34-7). Finally, the Luxembourg child-raising allowance was not a family allowance within the meaning of article 77 Regulation 1408/71. Its purpose was to replace income that was lost when a child was raised. Its amount did therefore not depend on the number of children as required by article 1(u)(ii) Regulation 1408/71 (para. 43). More generally, the Court ruled that articles $1(\mathrm{u})$ (i) and 10a Regulation 1408/71 did not establish a principle of non-exportability. Quite the contrary, those articles were just exceptions from the general rule that benefits could not lawfully be made subject to residence requirements (para. 26). Apart from those issues of scope, the Court also ruled in Leclere, 2001 that a pensioner was not entitled to rely on article 73 Regulation 1408/71, which applied to active workers, or any other article of the Regulation instead of article 77 Regulation 1408/71 which applied to pensioners claiming family allowances.

Skalka, 2004 was a judgment which again exclusively dealt with the question whether a benefit was 'special and non-contributory'. Austria granted a supplement to pensions to allow the pensioners concerned to maintain their standard of living, subject to certain ceilings. Since it was conditional on residence, $\mathrm{Mr}$ Skalka who lived in Tenerife was not entitled to claim the benefit under national law. According to the Court, the benefit was 'special', as it pursued an aim of social assistance in guaranteeing a minimum subsistence income. As such, it was linked to the socio-economic situation and the amount was determined by reference to the standard of living in Austria (paras 24-26). Moreover, it was 'noncontributory', since it was not in any way financed by contributions by the beneficiary (para. 29). Owing to the listing in annex IIa the benefit could therefore lawfully be made subject to residence pursuant to article 10a Regulation 1408/71.

In Hosse, 2006 the Court again dealt with a care allowance that was similar to those that had been at issue in Molenaar, 1998 and Jauch, 2001. The Court made it plain that 'social security benefits' and 'special non-contributory benefits' were two concepts that were mutually exclusive (para. 36). The Austrian municipal care allowance was not 'special', since it did not pursue aims of social assistance, but intended to improve the state of health and the life of persons re- 
liant on care. As such it supplemented sickness benefits and was to be considered as a sickness benefit pursuant to article 4(1)(a) Regulation 1408/71. It compensated additional expenditure arising from the need for care; its amount depended on the degree of reliance on care; and other income gained had no effect on the amount of the allowance (paras 38-42). The derived rights-approach, moreover, did not apply to sickness benefits under article 19 Regulation 1408/71 (para. 53). Therefore, a residence requirement was contrary to 19(2) Regulation $1408 / 71$.

Kersbergen, 2006 also concerned the categorization of a benefit as 'special and non-contributory', in this case the Netherlands' allowance for young disabled persons. It was 'special', because it provided a socially disadvantaged group with minimum means of subsistence. As such it constituted social assistance provided on the basis of socio-economic grounds. Moreover, the majority of the beneficiaries did not have any means without the benefit; and it was closely linked to the Netherlands environment for based 'on the minimum wage and the standard of living' in the Netherlands (paras 31-33). Since it was also 'noncontributory' for not linked in any way to contributions, a residence requirement was in order. Finally, the persons concerned in this case had made use of the freedom to move only after the residence requirement had been introduced in the relevant Dutch act. Therefore, acquired rights were not violated (paras 41-3). The interpretation delivered in Kersbergen, 2006 was fully confirmed in Hendrix, 2007 (paras 35-8).

In Perez Naranjo, 2007 the Court came back to the French supplementary allowance which Giletti, 1987 and Commission v. France (supplementary allowance), 1990 had held to be exportable. The Court assessed the allowance in the light of the case-law on the new article 10a Regulation 1408/71. While the allowance was 'special' for it pursued aims of social assistance (para. 34), the 'non-contributory' nature was more challenging. The supplementary allowance was financed by a general social contribution. However, the Court found that the link between that general contribution and the allowance was not sufficiently direct. The general contribution also served to finance other schemes; the institution concerned also had funds available from other sources; and the contributions did not necessarily come from the recipients of the allowance (paras 46-52). The French supplementary allowance which was listed in annex IIa was therefore within the ambit of article 10a and, hence, need not have been exportable. As a result, the Giletti, 1987-case-law was overruled on the basis of article 10a Regulation 1408/71.

Commission v. Parliament (special benefits), 2007 dealt with the amendment of article 4(2a) and annex IIa Regulation 1408/71 by Regulation 647/2005, which the Community legislature had enacted to fit the Regulation to the caselaw of the Court on special non-contributory benefits, notably the judgment in Jauch, 2001. The Commission did not challenge the adaptation of article 4(2a) as such. However, several benefits concerning disabled persons had been listed in annex IIa and thereby exempted from exportability. The Commission did not 
agree with this. The Court reviewed whether the five benefits challenged were 'special' in the sense of the case-law and the new article 4(2a). It first ruled that concepts of 'family benefit' and 'special benefit' were mutually exclusive. It then held all six benefits at issue, i. e. the Finnish and Swedish care allowances, the Swedish disability allowance, and the British disability living allowance, attendance allowance, and carer's allowance, not to be 'special'. While the benefits did 'promote the independence of the persons who receive[d] them and [did] protect the disabled in their national social context', that was not their sole purpose, since they also ensured the care and supervision of the disabled in their social context (all in para. 54; see the new article 4(2a)(a)(ii) Regulation 1408/71). However, the benefits did not fit under article 4(2a)(a)(i) Regulation 1408/71, either. Under that paragraph, a benefit had to 'either replace or supplement a social security benefit, while being distinguishable from it, and be by its nature social assistance justified on economic and social grounds and fixed by legislation setting objective criteria' to be 'special' (para. 55). Despite their specific characteristics (paras 58,60,63, and 66), all allowances were sickness benefits and as such not 'special'. Only the British disability living allowance included an element of social assistance, namely the mobility component, which the British legislature technically could split off. It would then be 'special' and could be made subject to a residence requirement (para. 69). That the British disability living allowance and the attendance allowance had been held to comply with article 10a Regulation 1408/71 in Snares, 1997 and Partridge, 1998 was not at odds with the new decision of the Court, since Jauch, 2001 had in the meanwhile introduced the examination of the 'special non contributory' nature of a benefit, in spite of its listing in annex IIa (para. 71). Hence, annex IIa was annulled in so far as it listed the five benefits at issue.

\section{Annex issues}

In Habelt, 2007, the Court transposed the Jauch, 2001-case-law to another annex issue. If the person concerned resided in Germany, Germany took into account periods of old-age insurance contribution completed during World War II in territories that had belonged to the German Reich at that time, but were not any longer part of modern day Germany. Annex VI(c)(1) to Regulation 1408/71 sanctioned that residence requirement. The Court first held that the scheme was within the scope of Regulation 1408/71, as the periods were not taken into account in recognition of efforts during the war within the meaning of article 4(4) Regulation 1408/71, and because contributions had been paid during that time (para. 66). That the institution which had administrated the scheme originally did not exist any longer was immaterial (paras 70-1). In analogy to the Jauch, 2001-line of authority it was not sufficient for a benefit to be listed in an annex to Regulation 1408/71 in order to validate a residence requirement and comply with article 42 Treaty, formerly article 51 Treaty. In addition - as with 'special non-contributory' benefits - the benefit had to be closely linked to the social environment. That was not the case for the German benefit of recognition of 
wartime periods of contribution. Hence, the residence requirement and the annex, in that regard, were contrary to article 42 Treaty (paras 81-4). Moreover, the Court confirmed the continued applicability of a convention that had been in force when the person concerned had moved to work in a member state before Regulation 1408/71 became applicable, in keeping with Rönfeldt, 1991 and Thévenon, 1995. That even applied when a person had moved to a member state from outside the Community (para. 121), provided that a link to the Community was given within the sense of the Prodest, 1984-line of authority (para. 121-3).

\section{Further scope and definitions}

In Noteboom, 2005 the Court categorized a Belgian benefit as an old-age benefit pursuant to article $4(1)(\mathrm{c})$ Regulation $1408 / 71$. 'Holiday pay' was granted to pensioners to supplement their pensions so that they could go on holiday. It was linked to the pension and financed by the same resources. Regardless of the facts that it was not funded by contributions and consisted in a flat-rate amount, it was an old-age benefit (paras 22-9). In De Cuyper, 2006, the Court again dealt with a Belgian benefit, namely an allowance which was granted as a means of subsistence to persons aged over 50 years who had lost employment. The Court discarded the argument that the benefit constituted social assistance, as it was granted without a discretionary assessment of the personal circumstances and based on an objective, legally defined position (para. 23). The allowance addressed the characteristic risk of loss of employment, was a substitute for the salary lost, and calculated on that basis. The amount of the allowance was determined in the same way as regular unemployment benefits. The allowance was subject to a minimum qualifying period of employment having given rise to social security contributions during a reference period. The exemptions from the obligations to register as a person seeking employment and to be available for work were immaterial. The allowance was thus an unemployment benefit (paras 27-31). Consequently, a residence requirement was not precluded by Regulation 1408/71. That outcome was compatible with the freedom of Union citizens to move pursuant to article 18 Treaty, as surprise monitoring was an appropriate method of ensuring that the conditions for the grant of the benefits continued to be fulfilled, in particular with regard to the family and employment situation of the person concerned. Less intrusive means than a residence requirement were not available (paras 41-6).

Finally, in Petersen, 2008 the Court dealt with a particular Austrian benefit. Persons resident in Austria were granted a benefit which served to bridge the period of uncertainty while a person was awaiting a decision regarding an invalidity benefit. Since that benefit was obviously only granted, if the person concerned did not work during that time, it was unclear whether the benefit was an invalidity or an unemployment benefit under article 4(1)(b) or (g) Regulation 1408/71. The benefit was considered retroactively as an unemployment benefit by national law, in case the decision on invalidity did not turn out in the affirmative. It was financed by the unemployment scheme, subject to refunding in case of invalidity. 
The purpose of the benefit was to replace income lost during the period of uncertainty. Moreover, the benefit was subject to the same conditions as unemployment benefits and calculated in the same way. Given those characteristics, the Court concluded that it was an unemployment benefit. That the person concerned was dispensed from being available for, capable of, and willing to work was irrelevant (paras 23-34). Consequently, a residence requirement would have complied with Regulation 1408/71, subject to article 69 and 71 Regulation $1408 / 71$ - if the Court had not invalidated it on other grounds, namely the indirectly discriminatory effects on the free movement of workers which could not be justified. The Court mitigated the ruling, though. The benefit was on average only available for three to four months. Moreover, the ensuing invalidity benefits in the event of an affirmative decision were exportable in any event pursuant to article 10(1) Regulation 1408/71, while the ensuing unemployment benefits in case of a non-affirmative decision were subject to articles 69 and 71 Regulation $1408 / 71$. Moreover, the return of the person concerned for checks could lawfully be required (paras 55-62).

\section{Applicable legislation: posted workers}

In the 2000s, the Court also decided several cases which mostly centred on the applicable legislation. With Fitzwilliam, 2000 the Court came back to Manpower, 1970, which had concerned posted workers under Regulation 3. The Court essentially confirmed the criteria developed in that decision for posted workers under article 14(1)(a) Regulation 1408/71. Two of the conditions to be met for article $14(1)(a)$ to apply, and hence for the 'home' state legislation to continue to be applicable, were that (i) the posted workers had a necessary link to the undertaking posting them in the sense that the undertaking had authority over them (paras 22 and 24) and (ii) that the undertaking posting workers normally conducted its business in the state where it was established (paras 23 and 30). Only that interpretation was in accordance with the exceptional nature of article 14(1) (a) (para. 41). The second point (ii) had to be deduced from all the circumstances, namely including the law applicable to the employment contracts of the posted workers, the places where those contracts had been concluded and where the workers had been recruited, the turnover, administration, seat, and staff of the undertaking, but not the nature of the work performed (paras 42-4). Apart from that, the E 101 certificate that posted workers took along to prove that they remained subject to 'home' state legislation pursuant to article 11(1)(a) Regulation 574/72 established a presumption that bound the host state authorities. Those authorities were, however, entitled to ask the 'home' state authorities to verify the certificate (paras 53-6). Banks, 2000 confirmed that latter point and added, on the one hand, that the person in the host state that (the person) called on the services to be performed under certificate $\mathrm{E} 101$ was also bound by it, and, on the other hand, that such certificates could also be issued with retroactive effect (paras 47 and 52-3). Moreover, Banks, 2000 clarified that 'work' within the meaning of article 14a(1)(a) Regulation 1408/71, which concerned 
self-employed persons who went to 'work' in another member state, included activities in an employed as well as a self-employed capacity (para. 23). Artists who were self-employed in the United Kingdom and went to 'work' in an employed capacity for a theatre in Belgium for several months therefore remained subject to the legislation of the United Kingdom. In analogy to posted workers pursuant to Fitzwilliam, 2000, however, a significant part of the persons' activities had to be performed for a certain amount of time where they were established. The circumstances - offices, value added tax number, registration, etc. were equally decisive here. The 'work' performed in the host state by such selfemployed persons, in addition, had to be genuine and clearly delimited in advance (paras 25-7). Such circumstances given, Belgium could not lawfully collect social security contributions from the Belgian employers for the 'work' of such self-employed persons. In Plum, 2000, the criteria developed in Fitzwilliam, 2000 were put to the test. The owner of construction companies in Germany had established a company in the Netherlands in order to benefit from the lower labour costs there by posting workers to Germany. The Court found that the purely managerial activities of the company in the Netherlands were not sufficient for it to conduct its business normally in the state of establishment within the sense of Fitzwilliam, 2000 (para. 21 of Plum, 2000) and hence to benefit from the scheme established by article 14(1)(a) Regulation 1408/71. In Herbosch Kiere, 2006, the Court confirmed the ruling delivered in the previous judgments as to the binding nature of certificate E 101. The Court added that the host state authorities could not have the certificate declared invalid by the courts in the host state, either. Such courts did not have the power to scrutinize the validity of the certificate as to the existence of a direct link between posting undertaking and posted workers. As long as the certificate had not been withdrawn by the state having issued it, the certificate remained valid (paras 30-2).

\section{One legislation}

Commission v. France (social debt repayment), 2000 concerned a charge France imposed on all income gained in France. The aim of the charge, 'the social debt repayment contribution', was to raise the funds necessary to redress a budgetary imbalance in the French social security system. The Court assessed that the charge was not a tax, but rather a social security contribution, since its purpose was to finance a deficit in the French general social security system. That sufficed to establish a direct and sufficiently relevant link between the charge and the social security system, notwithstanding that the charge was levied together with taxes and did not yield any concrete benefit for the person charged (paras 36-41). As a social security contribution, it could not be imposed without violating the principle that only one legislation was to be applied pursuant to article 13 Regulation 1408/71 and equal treatment in articles 48 and 52 Treaty on persons who, while residing in France, received income abroad and paid contributions to the social security systems of other member states pursuant to Regulation 1408/71 (paras 45-8). In Commission v. France (general social contribu- 
tion), 2000, handed down on the same day as Commission v. France (social debt repayment), 2000, the Court applied identical reasoning to the French general social contribution which fed the social security branches concerning old-age, survivor's, sickness, and family benefit and was designed to alleviate the burden on low- and mid-level incomes (paras 35-6). In contrast, in Commission v. Germany (artists' contribution), 2001 the Court validated a similar social contribution Germany charged on Belgian artists' remunerations paid in Germany. The crux was that according to German law the undertakings that marketed the artists' work and were liable to pay the charge were prohibited from passing on the burden of the charge to the artists. That prohibition had the effect that artists who were established in France and only occasionally performed work in Germany and who were therefore subject to French social security were not concerned - not even indirectly - by the German charge (paras 26-37). Thus, neither article 13 Regulation 1408/71 nor articles 51, 52, and 59 Treaty were infringed.

In Vogler, 2000 the Court declined, in an order, a challenge to the approach chosen by the Community legislature to address the situation of persons who simultaneously pursued self-employed activities in two member states. According to the Court, to rely on the residence of the self-employed person to determine the legislation applicable pursuant to article 14a(2) Regulation 1408/71 was not unreasonable. In laying down that rule, the Council did not commit a manifest error or misuse his powers (paras 24-7). Germany could therefore not lawfully impose social security contributions regarding farming activities in Germany of a person who at the same time was a hotelier in Austria where he resided. In a similar vein, the Court rejected a challenge in Allard, 2005. The Belgian 'moderation contribution' was within the scope of Regulation 1408/71, because it served to finance a Belgian social security scheme (paras 17-8). Pursuant to article $14 \mathrm{~d}(1)$ Regulation 1408/71 Belgium was not just allowed, but indeed required to levy social security contributions not only on the proceeds of the selfemployed activities in Belgium of a person resident there but also on the proceeds of that person's self-employed activities in France (para. 23). That requirement, moreover, did not violate the freedom of establishment (paras 32-3). The ruling in Allard, 2005 was, however, put in a different perspective in Derouin, 2008. This case concerned the two contributions which had been at issue in Commission v. France (social debt repayment), 2000 and Commission v. France (general social contribution), 2000. It was therefore obvious that those two contributions were subject to Regulation 1408/71. According to the ruling in Allard, 2005 France was entitled to levy those contributions on the entire income generated by a person resident in France through self-employed activities in France and the United Kingdom. However, France could forgo that right unilaterally or in a double taxation convention with the United Kingdom. According to the Court, Allard, 2005 could not be interpreted in the sense that France had to levy the charge equally on the income stemming from the self-employed activity in the United Kingdom (paras 27-30 of Derouin, 2008). 


\section{Ceasing occupation}

Elsen, 2000 raised the question whether article 13(2)(f) Regulation 1408/71 according to which the legislation of the member state of residence was applicable to persons who ceased work applied to the situation of Ms Elsen. She had worked in Germany, then moved to reside in France while continuing to work in Germany as a frontier worker. She had then given birth to a child whom she had raised while not continuing to work and not working later on, either. She claimed that the child-rearing periods were to be taken into account for her German old-age pension. The Court denied that article 13(2)(f) was applicable in that specific situation, because a close link existed between the employment in Germany, which had given rise to social security insurance there, and the following period of maternity (para. 26-8). German law was therefore applicable. The Court then went on to examine the German requirement that the child-rearing, essentially, had to take place in Germany, for the corresponding period to be credited towards the old-age pension. The Court explained that the freedom of movement of Union citizens had to be complied with even when the member states organized their social security systems. Regulation 1408/71 helped to guarantee not only the freedom of workers but also that of citizens. Hence, the German requirement was contrary to freedom of movement of workers and citizens (paras 29-36).

The Court also addressed article 13(2)(f) Regulation 1408/71 in Commission $v$. Belgium (contributions), 2001 and equally held that article not applicable, though for another reason. Belgium imposed social security contributions on occupational disease pensions paid in Belgium to persons resident abroad. The Court held that article 13(2)(f) was not to be applied generally, since it was uncertain whether any other legislation was applicable to the persons concerned and, in particular, whether the legislation to which each of the persons concerned had been subject previously in actual fact had ceased to apply (paras 29-32 and 38). Hence, the law of the member state of residence could not generally be held to be applicable when a person received a pension by reason of an occupational disease. Belgium was, therefore, not precluded on that general level from levying the contributions. In Laurin Effing, 2005, in contrast, the Court steered clear of article 13(2)(f). The person concerned in that case served a prison sentence in Germany, after having been transferred from a prison in Austria where his family lived and he had been employed previously. As he worked during the prison term in Germany, it did not matter whether article 13(2)(a) or (f) applied. In either case, German legislation was applicable to the person concerned (para. 45). Consequently, he did not have a claim to benefits on the basis of Austrian law and the residence requirement in Austrian law was not precluded either by Regulation $1408 / 71$ or by article 12 Treaty.

Van Pommeren, 2005 concerned article 13(2)(f), too. A person residing in Belgium had been compulsorily insured owing to employment in the Netherlands and then become incapacitated and received invalidity benefits in the Nether- 
lands. By reason of those benefits, the person continued to be subject pursuant to Dutch law to some branches of insurance on a compulsory basis, while for others continued insurance became optional. In those circumstances, the Court considered, article 13(2)(f) was not applicable, since the person concerned had not ceased to be subject to Dutch legislation (para. 36). However, the Court found discrimination in that the conditions of continued insurance for non-residents were less favourable than those under compulsory insurance which applied to residents. Notably, the levels of contributions were not the same. In the light of the low rate of affiliation to continued insurance in the Netherlands - which was indicative of difficulties encountered by non-residents - the Court concluded that article 39 Treaty was violated, because non-residents were put in a less favourable position than residents (paras 40-3).

\section{Two legislations}

Piatkowski, 2006 again dealt with an exception to the rule that only one legislation was applicable, namely article $14 \mathrm{c}$ (b) Regulation 1408/71 according to which two legislations applied in case of simultaneous employment in one state and self-employment in another. Mr Piatkowsi had been pursuing a self-employed activity in Belgium, while he was employed in the Netherlands as a director of a Dutch company. The Netherlands authorities treated the interest paid on a debt which a Dutch company owed him as income and subjected it to Dutch social security contributions. The Court did not find any issue with that. Despite the revision of article $14 \mathrm{c}$ which had deleted the passage 'as regards the activity pursued in its territory', still each member state was entitled to levy contributions on the part of the income generated in its territory (paras 28-9). That Regulation 1408/71 did not regulate the way interest on debts had to be attributed between two member states was irrelevant, since Belgium did not subject the interest paid to contributions (paras 30-1). Moreover, the Dutch levy applied without distinction, contributions were not left without return, and income was not subject to contributions twice for the same period of time. That the contributions levied on the debt did not afford any concrete additional protection was immaterial given that in a system of solidarity the protection afforded was independent of the amount of contributions paid (paras 30-38).

\section{Aggregation}

As to aggregation, the Court decided about a dozen of cases during the 2000s. In Engelbrecht, 2000, the Court dealt with essentially the same situation as in Van Munster, 1994, though the national provision at stake was different. Yet the provision still had the effect of reducing a married couple's pension in Belgium by switching from the household to the single rate due to the 'splitting' of a worker's pension in the Netherlands when the non-working spouse reached retirement age - a 'splitting' which did not increase the couple's overall pension in the Netherlands. That the non-working spouse's part of the split Dutch pension was partly based on periods of compulsory insurance in the Netherlands did not 
change anything in the assessment made in Van Munster, 1994. The national authorities still were not entitled mechanically to apply a national provision which had been plainly designed to deal with overall increases in a couple's income through retirement benefits, in a situation in which an overall increase had not taken place, else they violated the free movement of workers (paras 32-3, 41, and 43).

Insalaca, 2002 was a typical aggregation case in application of article 46 Regulation 1408/71. It arose because a Belgian provision was unclear (see the opinion of Advocate General Léger, paras 21 and 32). The effect of that provision was that the ceiling applicable to a Belgian survivor's pension which had been granted concomitantly with a Belgian old-age pension was lowered in the light of a simultaneously awarded survivor's pension in Italy. The Court, in application of standard case-law, classed that provision as a rule against overlapping which could not lawfully be applied in the calculation under the Community rules, viz. the calculation of the independent and pro rata amounts, in contrast to the calculation of the benefits pursuant to national law alone.

Barreira Pérez, 2002 dealt with particular years added in the calculation pursuant to article 46 Regulation 1408/71. Spain added certain years in the calculation of old-age pensions when those years concerned periods during which rights had been arising under the old Spanish retirement scheme. The Court decided that such notional years constituted periods of insurance pursuant to 1(r) Regulation 1408/71), even though they were not added in the qualifying period, but only in the calculation of the benefit (paras 25-6). As such they had to be fed into the calculation both of the theoretical amount as well as the pro rata amount under article 46(2), although those years did not relate to a specifically identifiable time period and potentially could overlap with periods of insurance completed in other member states (paras 34-41).

In Koschitzki, 2005 the Court was asked whether the Italian supplement to bring an old-age benefit up to the minimum pension was to be taken into account generally in the calculation of the theoretical amount under article 46(2) Regulation 1408/71 or merely when the person concerned was actually entitled to it. The Court clarified Stinco, 1998 which had not addressed the point and ruled that the supplement was to be included only when the person concerned was actually entitled to it (para. 29). When the income threshold was crossed and the person concerned was therefore not entitled to the supplement, the theoretical amount had to be calculated without it.

In Chuck, 2008 the Court was faced with the question whether article 48(2) Regulation 1408/71 concerning periods of insurance of a duration of less than one year also applied to a national of a member state who had worked in several member states, but resided in a non-member state, in this case the United States, when applying for an old-age benefit. On the basis of the scope ratione personae of Regulation 1408/71, which was based exclusively on the national of a member state having been subject to the social security system of a member state, the Court decided that residence in a third country was not an obstacle to the appli- 
cation of article 48(2) (para. 34). However, it was a matter of national law whether the benefit awarded based on that article was exportable to a third state (para. 38).

Leyman, 2009 concerned an intricate case in which Belgium's type A invalidity scheme was confronted with Luxembourg's type B invalidity scheme. In such a constellation, article 46 Regulation 1408/71 undoubtedly applied to invalidity pensions awarded. However, the Belgian system was based on a sequence of sickness benefits and invalidity benefits. During the first year, thus, a person received a primary incapacity allowance which was then followed by invalidity benefits, if need be. Because of that approach article 40(3)(b) Regulation $1408 / 71$ specifically provided that invalidity benefits were only acquired as per the date when the sickness benefits expired. However, in Leyman, 2009 that led to a peculiar situation. Ms Leyman had become invalid in Luxembourg and was awarded a pro rata invalidity pension there right from the first year on. However, based on article 40(3)(b) Belgium refused to award her a pension for the first year after having become incapable of work. Only for the period after that first year invalidity benefits were granted. In doing so, Belgium relied on Luxembourg's binding determination of invalidity which in Belgium could only trigger the benefit due after the first year of incapacity. According to the Court, Belgium's refusal disadvantaged migrant workers, since they lost a year worth of benefits in Belgium. In addition, contributions that had been paid there went without return. Therefore, based on the free movement of workers, good cooperation pursuant to article 10 Treaty, and despite article 40(3)(b) Belgium had to grant an invalidity benefit also for the first year of incapacity of work (paras 42-6).

\section{Aggregation and child-rearing in Austria}

Kauer, 2002 concerned periods of child-rearing which Austrian law generally took into account as substitute periods for old-age insurance purposes. Ms Kauer had worked in Austria. She had then stopped working. Without having received any benefits, she had given birth to three children whom she had mainly raised in Belgium after having moved there. She had never worked in Belgium and then came back to Austria to work in 1975. Austria refused to recognize those child-rearing periods as substitute periods, as (i) they had been completed before entry into force of the Agreement on the European Economic Area and (ii) because Ms Kauer had not received Austrian benefits during the periods. According to the Court, Regulation 1408/71 applied, because risks having materialized before entry into force of Regulation 1408/71 were relevant and the effects of situations having come about before that entry into force were on-going in accordance with articles 94(2) and (3) Regulation 1408/71. Austrian law applied to determine whether the periods were insurance periods within the sense of article 1(r) Regulation 1408/71, based on either Ten Holder, 1986 or article 13(2)(f) Regulation 1408/71 as interpreted in Elsen, 2000 due to the sufficiently close link to Austria (paras 29-33). The Court discarded the first condition (i) in the 
light of article 94(2) Regulation 1408/71 (paras 35-6). The second condition (ii) was also rejected. The condition violated article 94(2) in conjunction with articles $8 \mathrm{a}, 48$, and 52 Treaty (paras 44-9). Thus the periods of child-rearing had to be considered as periods of insurance under Austrian law as interpreted in the light of the Treaty. Via article 94(2) Regulation 1408/71 they had to be taken into account for the purpose of old-age insurance in Austria. Klöppel, 2008 also concerned the taking into account of periods of child-rearing in Austria, tough in different circumstances. Ms Klöppel had raised her child in Germany. Her partner helped her and received child care allowance in Germany for that purpose. When they moved to Austria, she received child care allowance in Austria. However, in the determination of the period for which the allowance was granted, it was not taken into account that her partner had received child-care allowance in Germany. As a consequence, the benefit was only granted for 30 months, rather than 36 months. The Court found that reduction to constitute indirect discrimination contrary to article 3 Regulation 1408/71 (paras 17-9).

\section{Aggregation and employment with the Community}

In $M y, 2004$ the Court dealt with insurance periods completed during work for the institutions of the Community. Mr My, an Italian national, had moved to Belgium as a child and later worked in Belgium and then for the Community. Belgium refused to take the insurance periods into account for the purpose of entitlement under Belgian old-age insurance. The Court refused to examine Union citizenship (paras 32-3) and reiterated that Regulation 1408/71 did not apply to officials of the Community. Regulation 1612/68 did not apply either, because Mr My's entire working life had been confined to Belgium. The situation was purely internal to Belgium. Employment with the Community was not the same as employment in the civil service of another member state (paras 39-42). Instead, the staff regulations of the Community applied. Based on those and the principle of cooperation, Belgium had to take into account those periods (para. 44 et seq.).

\section{Further aggregation}

In Salgado, 2005 the Court dealt with a Spanish unemployment benefit granted to persons aged over 52 years. Those persons received a particular benefit and Spain, in addition, paid old-age insurance contributions on their behalf. However, the periods during which that benefit was granted did not count towards the qualifying period of 15 years for Spanish old-age insurance, i. e. they were only taken into account in the calculation of an old-age benefit. The Court did not find an issue with that approach, since it was up to national law to determine which periods constituted periods of insurance pursuant to article $1(\mathrm{r})$ Regulation 1408/71. As the approach was not discriminatory and insurance periods completed abroad were factored in, the Spanish approach was compatible with the free movement of workers. In García Blanco, 2005, the Court declared 
inadmissible another question asked by a Spanish court as to the same Spanish scheme, since the claims of the applicant had already been met.

In Noteboom, 2005, the Court ruled that a frontier worker who drew unemployment benefits in Belgium based on article 71(1)(a)(ii) Regulation 1408/71, although he had been affiliated to the unemployment insurance scheme of the Netherlands, had to be considered to have been insured in Belgium for the purpose of entitlement to 'holiday pay' in the first year of retirement. That much followed from the 'as if'-clause for aggregation pursuant to article 45(6) Regulation 1408/71 (para. 34).

Nemec, 2006 concerned an occupational disease benefit awarded in France to those who were exposed to asbestos during their work. The benefit essentially allowed those persons to retire early. To determine the benefit in the case of $\mathrm{Mr}$ Nemec, the French authorities relied on Mr Nemec's last salary in France, although he had made use of his freedom and had gone to Belgium to work where he had earned a higher salary. According to the Court ruling on the basis of article 58(1) Regulation 1408/71, the French authorities did not have to take into account the actual salary gained in Belgium. However, they were not allowed to rely simply on the last salary paid in France, either, else migrant workers would be disadvantaged. Instead, they had to calculate on the basis of what $\mathrm{Mr} \mathrm{Nemec}$ would have earned had he continued to work in France rather than Belgium. In other words, the salary paid had to be updated and revalorized (para. 42).

\section{Sickness benefits, medical services}

The Court ruled on the basis of the provisions concerning sickness benefits in a number of cases in the 2000s. Vanbraekel, 2001 concerned the situation where the authorization to seek medical treatment abroad was granted retroactively after it had been refused previously. The question came up whether the costs the patient had faced due to the treatment abroad were to be reimbursed to him in accordance with host state or 'home' state legislation. In the case of the Vanbraekels' relative the cost of the treatment provided in France was lower than it would have been had the treatment been provided in Belgium, the 'home' state. The Court decided that article 22(1)(c) Regulation 1408/71 did not regulate the question. While article 22 did require the 'home' state institution to reimburse the person concerned directly in such circumstances, article 22(1)(c) left the 'home' state free to reimburse the lower cost actually incurred in the host state or the higher cost under its own system (paras 36-7). However, the freedom of services, i. e. the freedom of the recipient of medical services, required that the higher amount pursuant to the 'home' state legislation be reimbursed, else service recipients would be deterred from seeking medical services abroad (para. 45). In Inizan, 2003 the Court confirmed that the authorization scheme established by article 22(1)(c) Regulation 1408/71 complied with the freedom of services. The crux was that article 22 allowed persons to receive medical treatment abroad in accordance with the host state's legislation. That option would not be available without article 22. Accordingly, the Community legislature was enti- 
tled to attach conditions to that option (paras 22-4). Apart from that, when an authorization to seek intra muros medical treatment abroad was sought, the conditions for the refusal of the authorization applicable under article $22 \mathrm{had}$ to be interpreted in the same way as those the case-law under the freedom of services had developed for cases of medical treatment abroad. For clarity, the latter applied when medical treatment abroad was to be reimbursed in accordance with the legislation applied by the competent institution itself (see paras 19 and 52). Notably, it was required that the same or equally effective treatment was not available within due delay in the member state of residence (paras 45 and 59) and procedural safeguards applied (paras 48 and 57). France was, in particular, entitled to refuse the authorization only if equal medical treatment was available without undue delay in France. (See the case-law under the free movement of medical services below.)

In Bosch, 2004 the practice of a German sickness insurance fund to reimburse in full and without any formality expenses up to 200 German mark incurred by insured persons abroad was at issue. The German authorities opposed that practice. According to the Court, akin to Vanbraekel, 2001, article 34 Regulation $574 / 72$, which governed situations where an insured person was unable to complete the formalities required by Regulation 574/72 when receiving benefits abroad, was not to be interpreted so as to exclude the practice of the German fund, since it ensured that the person received the same, or even a higher reimbursement than if article 34 had been applied (paras 22-4).

In the case Keller, 2005 Ms Keller had received the authorization from the competent Spanish institution to be treated in Germany under article 22(1)(c) Regulation 1408/71. German doctors then decided that the particular operation she needed could only be performed in Switzerland. The Court held that the authorization granted in due form covered that situation, because sickness insurance according to German law would cover the cost of such an operation in Switzerland. Pursuant to article 22 Regulation 1408/71 the host state institutions applied the law of the host state and the authorized person had to be treated as if she were insured under host state law (para. 48). The Spanish authorities were therefore 'in the hands of the doctors authorised' (para. 50) and bound by their assessment even if it led to treatment in a non-member state. They could neither require the return of the person concerned nor reserve further approval. The authorization also covered vital treatment needed urgently which could not have been anticipated at the time the authorization had been granted (paras 53-60). The Spanish authorities had to reimburse the German institution, or the insured person directly, to the same extent as her operation was covered by German law (paras 67-9).

Watts, 2006 again concerned the authorization to receive intra muros treatment abroad. The Court confirmed expressly what had already been evident in Inizan, 2003, namely that the criterion 'within the time normally necessary for obtaining the treatment' in article 22 Regulation 1408/71 had to be interpreted in the same way as the term 'undue delay' used under article 49 Treaty (paras 
57-61). The Court also clarified the details of the medical assessment to be made in that regard. This was particularly important for the United Kingdom with its universal health system which was at stake in Watts, 2006 and which sometimes resulted in considerable waiting periods for patients. An 'exodus of patients' (para. 77) was therefore possible depending on the interpretation of Community law. The Court, in particular, held that all the circumstances of each case had to be assessed individually - for instance the medical condition and history of the patient and the degree of pain - if necessary flexibly and dynamically. Within that assessment, however, waiting periods, and waiting lists in particular, were not per se excluded, as already held in relation to the freedom of services, provided that the waiting period did not exceed what was acceptable in the light of the medical needs of the person concerned (para. 63). Potentially higher cost abroad were not to be fed into the assessment, though. The framework the Court described was necessary to prevent overcapacities, wastage, and imbalances in the medical system of a member state. (For the dimension of the freedom of medical services, see below.)

Acereda Herrera, 2006 next dealt with the extent of the cost covered when the authorization to receive treatment abroad had been granted. It was, in particular, uncertain whether certain ancillary costs were covered, such as the cost of travelling to the hospital, certain meals and accommodation outside the hospital, or the cost of relatives who accompanied the person for the treatment. With the benefits listed in article 22(1)(c) Regulation 1408/71 being exhaustive, the Court decided that only the cost directly connected to the medical treatment and cost linked thereto, like accommodation and meals in the hospital, were benefits in kind covered by article 22 Regulation 1408/71. In turn, cash benefits under article 22(1)(c)(ii) Regulation 1408/71, which was also a Community term, related to loss of income and was not to be interpreted to mean ancillary cash cost incurred in hospital treatment (paras 33-5). Consequently, certain ancillary cost was not covered by the authorization pursuant to article 22. That ruling, however, did not affect the assessment under non-discrimination, if the freedom of services was applicable.

In Von Chamier-Glisczinski, 2009 a person who was subject to German sickness insurance was receiving German home care benefits. When her medical condition deteriorated she moved to Austria to receive full care in a home of her choice. The German care benefits were then discontinued. The powers were clearly allocated in such a case, irrespective of whether article 19 or article 22(1) (b) and (3) applied, namely Germany provided cash benefits and Austria benefits in kind in accordance with Austrian legislation on behalf of the German insurance. The care benefits were benefits in kind, since they served to finance full inpatient care (paras 48-9). However, as Austrian law did not know such care benefits, the Austrian institutions were not obliged to provide them and the German institutions rightfully ceased providing them (para. 53), while Regulation $1408 / 71$ did not force Germany to stop providing them (paras 55-6). Since it was unclear whether Mr von Chamier had sought work in Austria, the above re- 
sult was not at variance with article 39 Treaty. Union citizenship in turn did not preclude the result, either, since it was the natural consequence of a lack of harmonisation in social security. It did not amount to discriminatory or disadvantageous treatment of a Union citizen that full in-patient care provided in a home in Germany would have been covered by German insurance, while care in a home in Austria was not covered. A guarantee that moving residence in such a constellation would be neutral did not exist in Union law (paras 85-7).

\section{Pensioners and sickness benefits}

In Rundgren, 2001 Finland's authorities levied sickness insurance contributions on pensions paid in Finland. In the case of Mr Rundgren, who was receiving a pension in Sweden and then moved to reside in Finland, Finnish law treated him as if he received a pension in Finland, because in theory he had a right to a state pension in Finland. That treatment had the effect, in fact, that contributions were levied on his Swedish pension. As Mr Rundgren's situation was within the scope of Regulation 1408/71, the Court interpreted article 28a Regulation $1408 / 71$ to mean that only the state that in fact paid a pension, i. e. Sweden, was entitled to deduct contributions. There was a connection between the actual provision of pensions and the obligation to bear the cost of benefits in kind (para. 47). Furthermore, by levying contributions, Finland required a pensioner to pay contributions for benefits which were actually payable by Sweden. Since $\mathrm{Mr}$ Rundgren did not receive any additional protection, either, Finland's approach was precluded by article 33 Regulation 1408/71 (para. 55). The waiver of reimbursement of the cost arising from the provision of benefits in kind in the convention between Finland and Sweden did not have an impact on that assessment (para. 62). The judgment in Nikula, 2006 dealt with the sickness insurance of a pensioner in Finland, too. However, the circumstances were slightly different. Ms Nikula received two pensions, one in Sweden and one in Finland, while she was resident in Finland. In such circumstances, the Court concluded that Finland could take into account the pensions paid in Finland and Sweden to determine the income on the basis of which the sickness insurance contributions due in Finland were calculated. The only caveats the Court applied was that the contributions levied as a consequence in Finland were not to be higher than the pension paid in Finland pursuant to article 33(1) Regulation 1408/71 and that, if the Swedish pension had already been the subject of sickness insurance contributions earlier on, Finland was not to factor it, or the part of it concerned, into the Finnish calculation (paras 32-6).

IKA, 2003 also concerned a pensioner, though with regard to medical treatment abroad. Greek law established an ex post facto authorization for treatment abroad that was given, if the illness had manifested itself abroad and treatment had become necessary immediately. The Court interpreted article 31 Regulation 1408/71, which required that intra muros treatment had become necessary abroad, i. e. treatment abroad had not been planned. That article need not have been interpreted in harmony with article 22(1)(a) Regulation 1408/71, which 
dealt with the same question for (self-)employed persons but required immediate necessity of treatment, since the Community legislature wanted to create a special regime designed for the specific needs of pensioners (para. 38). In that light, Greek law could not lawfully require an authorization as such or, indeed, that treatment had become immediately necessary during a stay abroad and that the illness had come to light abroad (paras 41-3). Consequently, the direct reimbursement of the cost advanced by the patient could not lawfully be subjected to those conditions, either (para. 62). In contrast to IKA, 2003 the judgment in Van der Duin, 2003 dealt with planned medical treatment of pensioners abroad. In that case Mr Van der Duin, a pensioner, was resident in France and registered there in accordance with article 28 Regulation 1408/71. He went to seek hospital treatment in the Netherlands, the state in which he received his invalidity pension. It was doubtful whether the authorization scheme in article 22(1)(c)(i) Regulation 1408/71 was applicable in such a case. The Court replied in the affirmative, because the regime Regulation 1408/71 set up for pensioners residing abroad was based on the idea that those pensioners received benefits in kind in the host state as if they received pensions from the host state. It was different from the regime applicable to persons in active employment. The cost incurred by reason of a pensioner's medical treatment in the host state were reimbursed by the state paying the pension by lump sum based on the average cost caused by a pensioner. If the authorization scheme did not apply and a right to receive benefits in the state paying the pension existed for pensioners registered abroad pursuant to article 28 Regulation 1408/71, a risk would arise that the state paying the pension would face the cost caused by a single pensioner twice (paras 40-6).

\section{Unemployment benefits}

Thelen, 2000 continued the Court's case-law on unemployment benefits in the 2000s. In Thelen, 2000 the Court transposed its case-law as to rights acquired under conventions that applied when the Regulation entered into force to unemployment benefits (para. 19). In the case of $\mathrm{Mr}$ Thelen, it was a convention between Germany and Austria which allowed him as a German national to return to Germany and claim unemployment benefits there, while his work in Austria was taken into account for the German qualifying period. Under the regime of Regulation 1408/71 which entered into force for Austria when it joined the European Economic Area he could only claim benefits in Austria. The exportability of benefits was subject to article 69 Regulation 1408/71. For the Court there was no reason not to apply the Rönfeldt, 1991-line of authority. Mr Thelen had moved to Austria at a time when Regulation 1408/71 had not yet been in force and so he could legitimately expect the convention to apply (para. 22). The short interruptions in his employment in Austria, one of which happened to fall on the date of entry into force of the Agreement on the European Economic Area, did not deprive him of his rights under the convention (para. 21). In Kaske, 2002 the Court further clarified that case-law, again with regard to the 
convention between Germany and Austria. The Court made it clear that movements between member states which the worker concerned made after the entry into force of Regulation 1408/71 did not have an impact on the worker's established rights under a convention that had been in force when the worker first moved to a member state and neither did subsequent interruptions of employment. The situation of such a worker as regarded unemployment benefits had to be assessed entirely in the light of the more favourable convention (para. 32). Regulation 1408/71 only applied once the rights under the relevant convention had been exhausted, in other words typically when the basis of the worker's rights was laid entirely after entry into force of Regulation 1408/71, for instance when all the periods giving rise to a right to benefits were completed after entry into force of Regulation 1408/71 (paras 33-4). Quite apart from that, Austria could not lawfully provide that a worker was entitled to claim unemployment benefits in Austria, instead of the competent state pursuant to Regulation 1408/71, if that person had previously stayed in Austria for at least 15 years, for that option would result in discrimination (para. 38).

In Stallone, 2001 Belgium's increase of unemployment benefits for heads of household was at stake. Belgian law increased unemployment benefits by five per cent when the unemployed person, the spouse and the children who were dependent on the unemployed person lived together. The Court found that the condition implicitly amounted to a residence clause which was prohibited under article 68(2) Regulation 1408/71, for it amounted to indirect discrimination. It was therefore not to be applied, not even for reasons of monitoring, when the family of the unemployed worker lived in another member state (paras 16-22). Ruhr, 2001 confirmed that Kermaschek, 1976 was still good law for unemployment benefits (para. 21). A spouse who was a third country national and had worked in Luxembourg, while residing with her German husband in Germany, could not rely on article 71 Regulation 1408/71 to claim unemployment benefits, since she only enjoyed rights derived from her husband. Whether the husband had himself made use of his freedom under article 39 Treaty was immaterial.

In Verwayen, 2002 the Court ordered that the aggregation of periods pursuant to article 67(1) and (2) Regulation 1408/71 only applied when insurance or employment periods had been last completed in the member state from which benefits were claimed. Since that was not the case of Ms Verwayen, article 67 Regulation 1408/71 did not apply (para. 25). Kristiansen, 2003 mostly concerned the Commission's conditions of employment and the unemployment benefits that could be claimed by reason thereof. However, the Court also rejected the claim of Ms Kristiansen of being discriminated as a post-graduate fellow. Belgium was not required to take periods completed as such a fellow into account under the national unemployment scheme, as long as similar periods were not taken into account for Belgian nationals, either. The fact that some member states considered such periods as relevant under their unemployment schemes was irrelevant (paras 36-9). 


\section{Exporting unemployment benefits}

Rydergaird, 2002 concerned the 'export' regime for unemployment benefits set up in article 69 Regulation 1408/71. Swedish law offered a special benefit to a parent who had to take care of a sick child. That benefit interrupted Swedish unemployment benefits. The question in Rydergård, 2002 arose whether the period of four weeks under article 69 during which one had to have received unemployment benefits in order to rely on the possibility to 'export' the benefit had to be continuous. The Court reiterated that the regime set up by article 69 went beyond mere coordination and established proper, exhaustive criteria to be fulfilled. However, national law still determined unemployment benefits, and in particular the condition when a person could be considered to have been available to the unemployment services of a member state (paras 25-6). It was not required, though, that the person concerned had been receiving those benefits continuously, provided that the total period amounted to at least four weeks (para. $31)$.

\section{Unemployed frontier workers}

In De Laat, 2001 the Court dealt with partly unemployed frontier workers. 'Wholly' and 'partially unemployed frontier workers' were Community terms in need of uniform interpretation under article 71(1)(a) Regulation 1408/71 (paras 16-8). A partly unemployed frontier worker was supposed to receive unemployment benefits in the conditions most favourable to finding new employment, like all other unemployed workers, and only one social security legislation was to apply to him. For partly unemployed frontier workers the institutions of the place of residence would not be well placed to help the worker find new employment. A worker who used to work full-time and then was forced to reduce to part-time work maintained the links with the state of employment. He could therefore only lawfully claim benefits in the member state where he was still employed. Only when those links were totally severed would he become a wholly unemployed frontier worker who was entitled to claim benefits in the state where he resided (paras 31-6). Commission v. Netherlands (frontier worker), 2003 made it plain that the 'export' regime of article 69 Regulation 1408/71 applied also in the context of wholly unemployed frontier workers which were covered by article 71(1) (a)(ii) Regulation 1408/71. Since such workers were only entitled to unemployment benefits from the member state where they resided, that state also had to make available the three months 'export' option to them, when they wanted to seek work in a third member state, i. e. a state other than the member states of former employment or of residence.

In Adanez-Vega, 2004 a Spanish national who was born in Germany had lived most of his life in Germany, except for a training spell in Spain. He went to serve in Spain's military. Thereafter his claim for unemployment benefits in Germany was rejected for he failed to meet the qualifying period within the reference period, because the period of military service was left out of account. Subject to the national court's assessment of the facts, in particular of whether $\mathrm{Mr}$ 
Adanez-Vega had maintained residence in Germany during military service, the Court found that German law was applicable by reason either of article 13(2)(f) Regulation 1408/71 with residence being the relevant factor, after the Spanish legislation pursuant to article 13(2)(e) had ceased to apply (paras 23-6), or of article 71(1)(b)(ii) with a worker who was employed in another state than where he resided making himself available to the unemployment services of the state of residence (paras 32-40). However, it was essentially up to Spanish law to determine whether the period of military service constituted a period of employment. If that was the case, Germany would have to aggregate the period pursuant to article 67(3) Regulation 1408/71, if a period had lastly been completed in Germany, except when article 71(1)(b)(ii) applied (para. 49). In that regard, it was irrelevant how much time had lapsed between the period last completed and the point in time when the application for benefits was made, if no other period had been completed in the interim (para. 52).

\section{Family benefits}

Family benefits were addressed by the Court in a number of decisions in the 2000s. In Humer, 2002 the Court came back to the advanced maintenance payments by the Austrian state which had been at issue in Offermanns, 2001 (and later on in Laurin Effing, 2005, see above). In Humer, 2002 the Court added that a minor child whose parents were employed was able to rely on articles 73 and 74 Regulation 1408/71. Its claim to family benefits following a divorce of the parents was, moreover, not excluded by Regulation 1408/71 (para. 42). When the child moved residence with one of its parents who went to reside in another member state, Austria was not to rely on a residence requirement vis-àvis the child. For articles 73 and 74 to apply it need not necessarily have been the worker who moved residence, it could be the members of his family, too (paras 48-9). Moreover, not just the worker and the spouse were entitled to apply for family benefits under articles 73 and 74 , but also other family members, such as the child, since an individual was not to be considered in isolation under those articles (paras 50-1).

In Maabeimo, 2002, a Finnish benefit was at stake. Finland offered a place in a nursery for each child. However, parents could also instead opt for a home care child allowance, if they preferred to care for their child themselves. When Mr Maaheimo was posted to another member state for a year under his employment contract in Finland and his wife accompanied him, the allowance was discontinued because of a residence requirement. According to the Court, the allowance was a family benefit, because it was designed to meet family expenses and alleviate the financial burden on the family (para. 26). Since Finnish law continued to apply to a posted worker pursuant to article 14(1)(a) Regulation 1408/71), article 73 Regulation 1408/71 applied in such a case, because the place of residence differed from the place of employment. Moreover, the benefit was not listed in annex IIa as not exportable. Hence, in particular in the light of 
the option to choose the home care allowance instead of care in a nursery, the residence requirement was precluded (paras 30-5).

Dodl and Oberhollenzer, 2005 brought the Court back to Austria. In each of the two cases at hand, a wife had worked in Austria, while residing in Germany with her husband who worked in Germany. When she stopped working in Austria due to maternity it was unclear which of the two states had to supply a child raising allowance. Germany relied on the husband and refused an allowance, because he worked. Austria in turn refused an allowance, because the wife did not work, since her employment was suspended according to Austrian law and she did not reside in Austria. Provided that the national court found that the wife was insured in Austria within the sense of Regulation 1408/71 (paras 31-3), according to the Court, in principle the state of employment, i. e. Austria, as the competent state pursuant to articles 13(2)(a) and 73 Regulation 1408/71, was obliged to grant the allowance. However, in the cases at issue a risk of overlapping of benefits arose. In Germany benefits could be due owing to one of the parent's residence, while in Austria they could be due at the same time owing to the wife's employment (para. 50). In such a situation, article 10 Regulation 574/72 as interpreted in McMenamin, 1992 applied, since employment in the state of residence was given when the couple was considered as a whole. Thus, the reversal of priorities in article 10(1)(b)(i) Regulation 574/72 applied, suspending the competence of the state of employment of the wife in favour of the state of residence, although the husband was not himself entitled to an allowance because of his work in Germany. A proviso was, however, that the wife was entitled to the allowance in Germany, which was the case due to residence (paras 57-62). In the second case, however, the allowance in Germany was excluded, because the income threshold was crossed. The reversal of priorities was then not justified and Austria had to grant the allowance (paras 62-3). This ruling was confirmed later by the Court in Weide, 2005 for a constellation concerning Luxembourg and Germany. The Court merely clarified what had already been implicit in Dodl and Oberhollenzer, 2005, namely that a top-up payment, i. e. a supplement to guarantee the higher benefit pursuant to national law, in that case Luxembourg law, was required (para. 33). In Bosmann, 2008, however, the constellation was slightly different. Ms Bosmann alone was working in the Netherlands, while she resided with her family in Germany. A reversal of priorities was not triggered in those circumstances. Article 10(1)(b)(i) Regulation 574/72, i. e. the Dodl and Oberhollenzer, 2005-precedent, did not apply, since work was not performed in the state of residence, Germany; neither did article 10(1)(a) Regulation 574/72 apply, because a benefit was not due in the Netherlands, since the children had already passed the age of 18 years (paras 22-5). Therefore, the Netherlands were the regular competent state to provide family benefits. That those benefits had expired in the Netherlands, in contrast to the family benefits under German law, did not imply that Germany was consecutively required by Regulation 1408/71 to grant benefits (para. 27). However, Regulation 1408/71 was not to be relied upon to exclude a benefit that was indeed due under Ger- 
man law alone. More specifically, the German authorities could not lawfully discontinue the payment of the family benefit when Ms Bosmann took up work in the Netherlands after having previously worked in Germany, solely on account of Regulation 1408/71, while German law on its own would require granting the benefit by reason of residence as the sole criterion (paras 27-32).

In Slanina, 2009 family benefits in Austria had been discontinued, because the mother had moved to reside in Greece with the child. She did not work in Greece, while her former husband, the father of the child, worked in Austria. Subject to the national court's assessment that the child was a member of the family pursuant to article 1 (f)(i) Regulation 1408/71, the Court decided that Austria had to continue to pay family benefits in application of article 73. As held in Humer, 2002, the fact that the parents were divorced was irrelevant. Moreover, a family member was not to be considered in isolation. The Austrian benefits could only lawfully be discontinued pursuant to article 76 Regulation $1408 / 71$, if the mother took up employment in Greece and if - and in so far as she thus became entitled to family benefits in Greece.

\section{Family benefits and pensioners}

Martinez Dominguez, 2002 concerned the claims of pensioners to family benefits pursuant to articles 78 and 79 Regulation 1408/71. Several persons who were receiving pensions in both Germany and Spain were granted family benefits in Spain, because they were resident there. When the children who were the beneficiaries of the family benefits turned 18 years of age the Spanish benefits ceased. In other cases, the conditions for the award of family benefits in Spain were not met in the first place due to an income ceiling or an option exercised. In those circumstances, the Court judged, those children could not pursuant to articles 77(2)(b)(i) or 78(2)(b)(i) fall back on Germany's family benefits, although German family benefits expired only when the children were older or the benefits would have been available in the first place. As already held in Bastos Moriana, 1997 and Gómez Rodríguez, 1998, the crux was that the German pensions had been awarded in application of Community law. Only when the pensions had been awarded on the basis of national law alone, could the German right to family benefits be activated after the Spanish benefits had come to an end or had not arisen in the first place (para. 25). The same applied if the pension had been awarded on the basis of a convention which had been preserved owing to the Rönfeldt, 1991-line of authority, as clarified by Kaske, 2002. That case had to be treated as if the relevant pension had been awarded in application of national law alone (para. 31).

\section{Non-discrimination}

In a number of social security cases in the 2000s the Court dealt with non-discrimination. Some of those cases have already been discussed, like Commission $v$. France (social debt repayment), 2000. In that case the Court found that the French levy on salaries gained abroad and subject to social security there violat- 
ed the principle that only one legislation was applicable (see above). For the same reason the Court found that non-discrimination was violated. The principle that only one legislation was to be applied to one and the same worker at a time implemented the principle of equal treatment inherent in articles 48 and 52 Treaty. France had thus created an obstacle which could, furthermore, not be justified by the facts that the contribution levied was minor or that only a limited number of workers was concerned (paras 45-9). The Court ruled identically in Commission v. France (general social contribution), 2000 (paras 42-6).

Sehrer, 2000 was about a rather particular situation. Mr Sehrer, who was resident in Germany, received an old-age pension in Germany and a supplementary pension in France. Germany subjected the German pension to sickness insurance contributions and added the gross amount of the French supplementary pension, although a French solidarity contribution which fed France's sickness insurance funds but yielded no benefit to Mr Sehrer had already been levied on the latter pension. (The validity of the latter contributions was not challenged in the national proceedings.) As the French pension was paid pursuant to an undeclared industrial agreement, Regulation 1408/71 did not cover it pursuant to article 1(j) Regulation 1408/71. Mr Sehrer, therefore, had to be treated as if he received only one pension, namely in Germany. In those circumstances, Regulation 1408/71 did not apply (para. 27). Instead, article 48 to 51 applied, since his pension was intrinsically linked to his former status as a worker. The German approach, however, disadvantaged those who had made use of their freedom, while it did not so for those who had remained in Germany. Only for the former a risk existed that sickness insurance contributions would be levied twice on the gross amount of their pension (para. 34). Germany could therefore not subject the gross amount of the French pension to contributions again.

In Borawitz, 2000 Germany distinguished between retroactive pension payments made within Germany and payments directed toward another member state. Such payments in general were only to be made if they exceeded a certain minimum amount. That amount, however, was lower for payments made within Germany than for those directed to another member state. The Court found that this approach clashed with non-discrimination pursuant to article 3 Regulation $1408 / 71$. It essentially had the same effect as a residence requirement, since it affected those residing in Germany less than those living abroad (para. 28). The latter, however, were typically nationals of other member states. There were proportionately more nationals of other member states among those receiving a German pension while residing abroad than among those receiving such a pension while residing in Germany. In other words, the ratio, within the group of persons living abroad and receiving a German pension, between Germans and nationals of other member states had to be compared to the same ratio within the group of person living in Germany and receiving a pension. Since the first ratio was greater in the case at hand, there was indirect discrimination (paras 29-31). While additional expenses could in theory justify the approach, Germany used a clearing system which had the effect that the cost of payments to recipi- 
ents established abroad were not different than those of domestic payments. Moreover, the payments could technically just be added to the next tranche of the pension paid in Germany (paras 33-4). Thus, the indirect discrimination was not properly justified.

With Hervein II, 2002 the compatibility of Regulation 1408/71 with articles 48 to 52 Treaty was questioned in so far as it provided in article $14 \mathrm{c}(1)(\mathrm{b})$ in conjunction with annex VII that the legislations of two member states applied at the same time when a person was simultaneously employed in one member state and self-employed in another member state. The Court held that the validity of article $14 \mathrm{c}(1)(\mathrm{b})$ could only be judged on its own. The differences resulting in terms of contributions and benefits as such were due to a lack of harmonization and the fact that separate national systems remained in existence (para. 54). The Court admitted that the regime applicable pursuant to article $14 \mathrm{c}(1)(\mathrm{b})$ was liable to complicate matters in some cases, as the application of merely one legislation was easier. However, even if only one legislation applied in a given situation similar problems were liable to arise, since typically there were different compulsory schemes within the legislation of one and the same member state which applied to employment and self-employment (paras 55-7). Furthermore, migrant 'workers' could not expect 'neutrality as regard[ed] the complexity [...] of the administration of their social security cover' (para. 58). The Council thus validly undertook to coordinate the social security dimension of such cases and made special provision for them. Finally, even under article $14 c(1)(b)$ it was required that social security contributions basically did not go without return in terms of additional social security protection for the migrant worker (para. 64) and the Rönfeldt, 1991-caveat concerning social security conventions had to be respected.

Gaumain-Cerri, 2004 concerned Germany's care allowance scheme, which incidentally also covered the old-age insurance contributions of the third person providing home care to the person insured under the German care scheme. However, those contributions of third persons were only provided, if that third person or, as the case may be, the person reliant on care was resident in Germany. The care allowance was in keeping with Molenaar, 1998 part of a sickness insurance scheme and the part covering the old-age insurance contributions of the third person a cash sickness benefit for the person reliant on care despite the fact that, sometimes, a private insurer offered the insurance (paras 20-1 and 27). Thus, German legislation applied to the benefit (paras 28-30). There was no need, though, to determine whether a third person providing the care was a worker, because his or her Union citizenship precluded Germany from relying on residence in Germany as a requirement. The requirement established a difference in treatment in comparable situations. Thereby, it discriminated against Union citizens who had made use of their freedom to reside in another member state, while providing care in Germany. Hence, Germany could not lawfully refuse to cover the third persons' old-age insurance contributions under the care allowance scheme (paras 32-5). 
In Chateignier, 2006 the Court dealt with Belgium's unemployment insurance. In accordance with article 67 Regulation 1408/71, Belgium required that migrant workers had worked for at least one day in Belgium, before periods of work in other member states were aggregated for the purpose of Belgian unemployment benefits. However, for Belgian nationals that condition did not apply. They were directly entitled to claim unemployment benefits. According to the Court, that approach was contrary to equal treatment as laid down in article 39 Treaty and article 3 Regulation 1408/71 and, as such, was precluded.

In the judgment in Celozzi, 2007, a specific German practice was at stake. $\mathrm{Mr}$ Celozzi, an Italian national resident in Germany, had received daily sick pay under German sickness insurance commensurate with the categorization of his income for tax purposes. As a migrant worker, he had been categorized automatically for tax purposes as being separated from his wife, although in reality he was not separated from her; she had just kept residence in Italy. Upon his application he was subsequently re-categorized as married for tax purposes, which had the effect of entitling him to higher sick pay. However, that effect was limited to future sick pay. He applied for the higher sick pay with retroactive effect, i. e. right from when he was first sick, but that application was rejected, for retroactive effect was usually not granted. The Court judged that German practice to be contrary to non-discrimination in article 3 Regulation 1408/71. Sick pay clearly was a cash sickness benefit. Hence, Regulation 1408/71 applied. The German practice of automatically categorizing migrant workers and of refusing retroactive effect when the categorization had been rectified subsequently, for the purpose of sick pay, worked to their disadvantage and was indirectly discriminatory. In particular, the fact that a migrant worker was not informed of a possible change in categorization and that documentation involving the home state was required for re-categorization put him in a less favourable position (paras 31-2). Administrative difficulties - if they were capable of providing justification at all - did not justify the German approach, in particular since retroactive rectification was possible in at least one other case under German law (para. 39).

\section{Agreements with third countries, Ankara}

Social security Agreements with third countries were also addressed by the Court in a few decisions. Alami, 2003 was an application of Kziber, 1991. The Belgian seniority supplement to unemployment benefits for workers beyond 50 years of age was an unemployment benefit within the scope of Regulation 1408/71 and, thus, of the Rabat Agreement with Morocco, although it was not mentioned in its article 41(2) (para. 25). As non-discrimination applied pursuant to article 41(1) Rabat Agreement, Belgium could not lawfully require in the case of Moroccan nationals that an international agreement provided for the aggregation of employment periods completed in France in order to meet the Belgian qualifying period, while it did not so require for Belgian nationals (paras 33-4). Öztürk, 2004 regarded a similar constellation under the Ankara Agreement. Mr Öztürk 
had worked in Germany and Austria and was receiving in Germany, where he was resident, an early retirement benefit because of old-age unemployment. The corresponding benefit in Austria was refused, as periods completed in Germany were not aggregated for Austria's qualifying period. The Court decided first that Decision 3/80 did not just apply in the member state where the Turkish worker was resident, but in all member states (paras 51-2). Then the Court ruled that the case was not about a question of technical aggregation, which could not be solved in the absence of provisions implementing Decision 3/80, like Regulation 574/72 for Regulation 1408/71. Rather, it was a simple question of taking into account periods completed abroad for a minimum qualifying period (paras 63-5). Non-discrimination pursuant to article 3(1) Decision 3/80 - which also caught the measure at hand since it was liable to affect Turkish workers more than Austrian workers - precluded Austria's refusal to take into account the German periods. That refusal could, moreover, not be justified by the employment policy goal of the early retirement benefit, as it was an old-age rather than an unemployment benefit (para. 67).

In Echouikh, 2006 France refused to award an invalidity pension based on service in the French army in Indo-China during the 1950s on the ground that Mr Echouikh was not French. Mr Echouikh, a Moroccan national, had claimed that pension based on the Brussels Association Agreement with Morocco which had replaced the Rabat Cooperation Agreement. The Court transposed the relevant Rabat Agreement case-law to the Brussels Agreement, inter alia regarding the direct effect of non-discrimination pursuant to article 41(1) Rabat Agreement and article 65(1) Brussels Agreement. A pensioner had to be considered a worker for the purpose of a pension. Service in the army constituted 'work' and a link to France was given, although he had worked abroad, since he had served in the French army (paras 46-7 and 54). Non-discrimination, therefore, precluded France from relying on the Moroccan nationality to refuse a pension (paras 58-60) and it was not necessary to enter into any fundamental rights issue (paras 64-5).

El Youssfi, 2007 concerned a Moroccan national resident in Belgium who in vain claimed the minimum income guaranteed for elderly persons in Belgium. As held in Nemec, 2006, Regulation 883/2004, the successor to Regulation $1408 / 71$, did not yet apply for lack of implementing legislation. Regulation $1408 / 71$ had been amended to extend its scope to third country nationals. However, that applied only as far as the situation of such third country nationals concerned at least two member states. Since Ms El Youssfi's situation was confined to Belgium, she was not within the scope of the amended Regulation 1408/71 (paras 41-3). Hence, it was only the Brussels Association Agreement that applied. The benefit was a social security benefit within the meaning of Regulation 1408/71 and the Brussels Agreement (para. 60). The derived rights-approach did not apply under the Agreement in any case (paras 61-2). Ms El Youssfi could lawfully claim the benefit either herself if she had worked, through her husband if he was a worker, or through her son if he was a worker (paras 63-70). Conse- 
quently, the guaranteed minimum income could not lawfully be refused on the basis of Ms El Youssfi's Moroccan nationality (paras 54-5). Fundamental rights needed to be applied by the national court (para. 75). Furthermore, for completeness, the order in Haddad, 2004 has to be mentioned. The Court referred to it twice in Echouikh, 2006. It apparently concerned the application of the Rabat Cooperation Agreement to an unemployed student. However, apart from the notice in the Official Journal, which is inconclusive, no other information whatsoever has been published on the case.

\section{Technicalities}

Four more judgments dealt with more technical provisions implementing the coordination of social security. Camarotto, 2001 clarified based on Baldone, 1997 that article 95a Regulation 1408/71 applied not only to decisions that were final on 1 June 1992, but also to decisions that were taken in proceedings that had been brought before that date, but were still pending at that date. (The rest of the judgment concerned procedural issues of implementation.) In Gervais Larsy, 2001 the Court held that article 95a(4), (5), and (6) Regulation 1408/71 only applied when an application made for review of a pension was based on the more favourable new provisions inserted by amending Regulation 1248/92. It did not apply when an application concerned the provisions of Regulation 1408/71 as they had been in force before the amendment (para. 31). In applying article 95a(4), (5), and (6) Regulation 1408/71 to the case of Mr Gervais Larsy, the national court had, moreover, committed a serious breach of Community law giving rise to responsibility for damage caused (para. 34 et seq.).

Duchon, 2002 concerned the application of Regulation 1408/71 in Austria to the consequences of an accident that had taken place in Germany in 1968, i. e. before the accession of Austria to the Community. According to Austrian legislation (i) the qualifying period under Austrian disability insurance was waived only when the accident at work had been suffered by a person covered by the Austrian pension insurance scheme. The relevant reference period was, moreover, (ii) prolongated only for periods during which a benefit was received under the Austrian accident insurance scheme. The Court held that Regulation 1408/71 applied in such a situation pursuant to article 94(3) Regulation 1408/71, as the contingency had taken place before entry into force of Regulation 1408/71 but had 'future' effects. In other words, a pension was not claimed as from the accident in 1968, but as from 1 January 1998; it were only those effects, viz. benefits as from 1 January 1998 onwards which were at stake in the case at hand (para. 43). As the waiver of the qualifying period (i) worked to the detriment of migrant workers, it was precluded (para. 29). In the same vein, the prolongation of the reference period exclusively when Austrian benefits were received disadvantaged migrant workers in the sense of article 48 Treaty. In addition, in so far as article 9a Regulation 1408/71 expressly provided that possibility for national law, i. e. to exclude prolongation of the reference period when foreign benefits were paid, it was invalid in the light of article 48 Treaty (paras 38-40). 
In Pasquini, 2003 an application by analogy of the two-year limit in article 94 Regulation 1408/71 was rejected. The Italian authorities had overpaid an Italian pension due to a migrant worker, because they had not been aware that a pension was paid concurrently in Luxembourg. Consequently, the Italian authorities claimed back the amounts overpaid for more than thirteen years. The amount was more than 29'000 Euro. The Court decided that the two-year limit in articles 94 to 95b Regulation 1408/71 could not be applied to the claim for repayment, because it only concerned situations of transition (para. 54). However, for domestic pensions Italian law required a yearly review of income to avoid overpayment for more than a year. Based on the procedural Community principles of equivalence and effectiveness, that review had to apply to the pension at stake as well. As a result, an action for repayment was limited to overpayment for one year (paras 66-9).

\section{Further social security cases}

Finally, two more social security judgments were handed down in the 2000s. In Khalil, 2001 the Court was seized by stateless persons and refugees who wanted to rely on Regulation 1408/71. It was not in dispute that Regulation 1408/71 in general applied to such persons. Incidentally, however, the power of the Community legislature to regulate the social security issues pertaining to stateless persons and refugees, who as such did not enjoy the right of free movement, on the basis of article 51 Treaty was challenged. The Court rejected that challenge by means of a historical reading. Before Regulation 1408/71 had entered into force, the member states had already contracted obligations to treat stateless persons and refugees on an equal basis with their own nationals as regarded social security, notably in the Geneva refugee convention and the New York convention on stateless persons (para. 49). That was repeated in the European convention of 1957 which had served as a model for Regulation 3, which in turn served as the basis of Regulation 1408/71. Not to have included stateless persons and refugees would have meant to establish an entirely separate coordinating regime for those persons only (para. 57). The Community was thus justified in regulating the matter together with the coordination of social security of migrant workers. In the concrete case, however, the stateless persons and refugees could not lawfully rely on Regulation 1408/71, since their cases were all confined to one member state and no factor linked them to any situation governed by Community law (para. 69). They had all come to Germany directly from a third state. Their cases were therefore purely internal to Germany and as such not within the scope of Regulation 1408/71 (paras 69-71). In Commission v. Greece, 2004, finally, the Court confirmed without further ado Greece's failure to transpose in time Directive $98 / 49$ on safeguarding the supplementary pension rights of employed and self-employed persons moving within the Community. 


\section{Services}

\section{Posted workers}

In the 2000s, the Court decided a long series of posted worker cases. Mazzoleni, 2001 was the first. The posted workers directive 96/71 was not yet applicable (para. 17). Instead, the Court applied the freedom of services and clarified that the national authorities under proportionality had to take into account a number of points when the host state imposed a minimum wage requirement on the employees of a private security company located in the frontier zone, namely a rotation of the security guards could lawfully be required to carry out a contract with a company in the host state; the application of an additional legislation increased the administrative burden on the company providing the service; to apply the host state's minimum wage could result in wage inequalities within the work force of that company and thus create tension; and it was necessary to compare the overall situation of the workers, i. e. the salaries including social security and taxation (paras 30-40).

In Finalarte, 2001, in which the posted workers directive was not yet applicable, either, the Court confirmed the existing services case-law on posted workers, but gave the national court some indications on how to assess justification. Germany required businesses established abroad, like German businesses, to contribute to paid leave funds for the benefit of workers, be they posted or regular workers. The funds financed the salaries of construction workers during holidays which was necessary, because those workers usually worked for an employer only for a brief time. The Court emphasized that the additional burden for foreign businesses seemed to amount to a restriction (paras 35-6). A protectionist intent of the legislature when enacting a measure was not conclusive, but indicative, and called for a more careful, objective assessment by the national court (paras 38-42). That assessment needed to extend to the question whether the workers posted obtained a real, additional advantage owing to the contributions paid (paras 43-51). The Court then examined three distinctions Germany drew between foreign and German businesses with regard to the paid leave fund. (i) That, in contrast to regular German workers, posted workers themselves rather than their employer had a direct claim against the fund did not amount to discrimination, since that approach was more efficient and objective differences existed between foreign and German businesses (paras 62-4). (ii) That foreign businesses had to provide additional information could be justified, provided that controls could not be made on the basis of documents drawn up under 'home' state legislation (paras 69-74). (iii) Discrimination resulted from the fact that posted workers were always treated as a business and consequently became subject to German collective agreements in the construction industry, while German organisational entities in some circumstances were not treated as businesses (paras 81-2). 


\section{Construction business}

Commission v. Germany (contract labour), 2001 also dealt with the protection of workers in the construction industry, though not in the context of posted workers. German law prohibited the contracting out of labour to fulfil a contract, unless all parties involved within a consortium or, in general, parties belonging to the construction industry in essence were subject to the relevant collective agreements. This was the case for foreign companies only if they had an establishment in Germany (paras 14-7). Moreover, a German branch of a foreign company was only considered to belong to the construction industry and thus to be subject to the relevant collective agreements, if 50 per cent of the staff's working time was spent on construction sites. That requirement had the effect that foreign companies could not lawfully establish a branch in Germany for instance just to launch a project and later contract out labour. The Court, in briefest terms, found a restriction of the freedom of services because of the need for an establishment in Germany, a restriction which the protection of workers did not justify for it was not indispensable (paras 18-23). The working time requirement, in addition, violated the freedom of establishment, as it limited the possibilities for foreign companies to establish purely administrative branches, thus impeding their access to the German market (paras 31-6).

\section{More posted workers}

Portugaia, 2002 came back to posted workers, again in the construction business with Germany as host state, while Directive 96/71 on posted workers still did not apply. Germany imposed a minimum salary on the basis of collective agreements to be paid to all workers, including posted workers. In keeping with caselaw the Court accepted that approach, subject to the national court's assessment of necessity and proportionality as in Finalarte, 2001. Yet Portugaia, a Portuguese company posting workers to Germany, had to have the same possibility as German undertakings to negotiate special collective agreements which lowered the minimum wage, else discrimination resulted (para. 34).

Wolff \& Müller, 2004 for the first time applied Directive 96/71 on the posting of workers. German law provided that those German companies who contracted with companies in other member states to post workers to Germany had to guarantee the minimum rates of pay for the workers posted. Accordingly, a posted worker could basically claim her or his salary from two persons, namely her or his employer and the German company. The Court found that approach to be in compliance with Directive 96/71, which left the member states a large margin of discretion in implementation. As it had already been held that a minimum wage could be imposed as a justified restriction of the freedom of services, so could measures to implement a minimum wage (paras 36-7). Yet the national court had to determine whether a restriction arose at all and, under proportionality, examine the legislation at issue objectively and closely, given the protectionist aims pursued by the German legislature. Any practical difficulties in en- 
forcing the minimum salary against the German guarantor and the prevention of unfair competition also had to be taken into account (paras 33 and 38-42).

In Commission v. Luxembourg (posted workers), 2004 the Court assessed certain conditions Luxembourg law imposed when a company established in another member state posted third country nationals who were lawfully resident in that state to Luxembourg. Was required either an individual work permit issued by Luxembourg subject to the situation in the employment market; or a collective work permit, which Luxembourg exceptionally granted to the entire work force posted, if the workers concerned held employment contracts of indefinite duration with the posting company which had entered into effect at least six months previous to the posting. Moreover, a minimum bank guarantee was to be provided to secure the cost in case the workers needed to be repatriated. The Court found that the free movement of services was impeded, because an additional administrative and financial burden was imposed on the service provider (para. 23). The posting of third country nationals had not yet been harmonised (para. 25). According to the Court, the work permit mechanism was not appropriate to ensure the social protection of workers. A duty to report before the posting of workers would have been just as effective. The mechanism made the deployment of workers considerably more complicated. Short-term service provision became difficult. The social measures adopted by the 'home' state of the service provider or in an agreement concluded by the Community with a third state were not factored in, either (paras 30-6). The discretion the authorities had to grant the permit - they took the situation in the labour market into account was not warranted by the need to avoid disturbances of the labour market, since the posted workers did not seek access to that market (paras 38-43). An obligation imposed on the service provider to furnish information was, in addition, just as well suited to protect the labour market as the conditions relating to the employment contracts (paras 44-6). The bank guarantee was excessive, too. An order to pay the cost when third country nationals had to be repatriated was just as effective (para. 47). The free movement of services, thus, precluded Luxembourg's measure.

Commission v. Germany (minimum wage), 2005 concerned the elements to be taken into account under Directive 96/71 to determine the minimum wage to be paid under the law of the host state. The Commission had claimed that certain bonuses an employer paid to workers posted to Germany had to be taken account of when it was calculated whether those workers' remuneration was equivalent to the minimum wage payable by law in Germany. Germany had accepted most of the Commission's claims with regard to additional payments. As that acceptance was belated, the Court ruled that the Directive and the freedom of services had been violated (paras 29-33 and 41-2). For the rest, the Court ruled that the Commission's claims were either unclear or unfounded, because quality bonuses and bonuses for dirty, dangerous, or heavy work were not to be considered constituent elements of the minimum wage (paras 39-40). 
Commission v. Germany (posted workers), 2006 ruled in a similar vein as Commission v. Luxembourg (posted workers), 2004. The visa Germany required for third country nationals posted from another member state to Germany, which (the visa) was handed out within seven days without being subject to the authorities' discretion or any substantive condition, and the requirement that a worker posted to Germany had been employed for at least a year by the company posting her or him, both contradicted the free movement of services. A prior declaration, instead of an advance control measure resulting in a visa, sufficed to prevent abuse of the freedom of services and to guarantee the protection of the workers (paras 33-50). In particular, ensuring that a posting of workers was lawful was certainly in the interest of both the service provider and the host state, but the responsibility for unlawful conduct could not be imposed on those who did comply (para. 50). Furthermore, a simple prior declaration, rather than the condition of having been employed for at least a year, also ensured equally effectively that the worker was in lawful and habitual employment within the meaning of Vander Elst, 1994 with the company posting him or her to Germany (paras 55-62). Similarly, in the light of the option of a prior declaration, the Court struck down Austria's legal provisions applicable in cases of postings of third country nationals in Commission v. Austria (posted workers), 2006. Austrian law required the company posting workers de facto to seek prior authorization and to have employed the workers for at least a year or under non-temporary contracts (paras 41-57). Moreover, it was impossible by law to regularise on site the situation of workers lawfully employed but posted without visa (paras 61-7).

In Commission v. Germany (posted workers), 2007 the Commission again challenged some rules Germany imposed on undertakings posting workers to Germany. The Court decided that the Commission had failed to establish an infringement by the requirement that undertakings paid contributions to a German paid-leave fund on behalf of the workers they posted to Germany, unless a similar obligation existed in the 'home' state. It was not proven that the workers did not receive additional social security protection based on the contributions or that the requirement was disproportionate, as posited in Finalarte, 2001 (paras 50-54). The free movement of services was not infringed by Germany's requirement that the posting undertaking held available on site four documents in German for each worker, namely the contract, pay-slips, time-sheets, and proof of payment of wages. The restriction resulting from the additional expenses caused by that requirement was justified by the social protection of the workers and the need to monitor that protection. Monitoring would be extremely difficult if those four documents, which need not have been held available after the posting or the project had ended, were only accessible in a foreign language. The documents were often simple, for national law standardized them. A multilingual Community instrument did not exist. Information exchange between authorities was not an alternative, since the authorities in the 'home' state did not have those documents available (paras 66-79). In contrast, the notification of the au- 
thorities required when the posted workers began to work or changed the place where they worked violated the freedom of services. It was discriminatory, since German undertakings were not subject to such an obligation. As such it was only susceptible of justification by grounds expressly mentioned in the Treaty. None of those grounds was pertinent in this case, though (paras 84-7).

Laval, 2007 was handed down on the same day as Viking, 2007. Both cases raised similar issues, though in different circumstances, and the Court addressed them in the same way. In Laval, 2007 a Latvian company posted workers to Sweden to fulfil a construction contract through its subsidiary. The workers posted were subject to collective agreements in Latvia. Laval refused to conclude a collective agreement in Sweden, because an agreement necessarily left open in accordance with Swedish law for later negotiation the salaries to be paid to the workers. Swedish law, including the collective agreements, did not establish a mandatory minimum wage to be paid to workers. Because of Laval's refusal to conclude an agreement collective action was commenced. Ultimately, that collective action forced Laval to bail, its subsidiary in Sweden filing for bankruptcy. Since Directive $96 / 71$ on the posting of workers was applicable ratione temporis, the Court found that the freedom of services was to be applied in the light of the Directive. The Directive allowed a member state to lay down a mandatory minimum wage. Conversely, a member state, such as Sweden, could opt not to implement that option, but consequently it could not lawfully force a minimum wage upon an undertaking posting workers to its territory or an obligation to negotiate such a wage on a case-by-case basis. In a similar vein, Sweden could not require an undertaking posting workers to Sweden to comply with provisions going beyond the mandatory rules for minimum protection as laid down in the $\mathrm{Di}$ rective (paras 63-84). As ruled in Viking, 2007 for freedom of establishment, the Court held for freedom of services that collective action, including the right to strike as a fundamental right, was not outside the purview of the market freedom. The collective action taken to force Laval into complying with terms not made mandatory for all operators in the Swedish construction business constituted a restriction of the freedom of services. Balancing the market freedom against the social policy, including the protection of workers, mentioned in the Treaty, the Court found that the collective action as an obstacle to the freedom of services was not justified in a context in which national law did not establish a clear mandatory minimum wage (paras 86-110). Finally, a particular aspect of Swedish law amounted to discrimination. Swedish law in essence prevented Swedish unions from taking collective action to force amendment of a Swedish collective agreement. In case of a collective agreement concluded in the 'home' state by an undertaking posting workers, such as with the collective agreement concluded by Laval in Latvia, that obligation did not apply, resulting in the possibility for Swedish unions to take collective action and the impossibility for Laval to oppose that action. That distinction constituted discrimination which violated the freedom of services and for which the grounds expressly mentioned by the Treaty did not provide justification (paras 112-9). 
Rüffert, 2008 again concerned the posting of workers in the framework of Directive 96/71 and the freedom of services. A German company had concluded a contract with a German land to do construction work in a prison. In that contract, the German company had agreed as required by the law of the German land to abide by a collective agreement which contained a minimum wage to be paid to construction workers. The German company sub-contracted part of the work to a Polish company which then posted workers to the construction site in Germany. The Polish company paid those workers less than the minimum wage required by the collective agreement the German company had agreed to abide by. The Court refused to qualify that collective agreement as universal within the meaning of the Directive. The law of the Land seeking to make binding the collective agreement by means of a contract concluded with the contractor did not amount to a declaration of universal applicability, in particular because the German act implementing Directive 96/71 did not contain any provision having that effect and because the collective agreement covered only a part of the construction sector. Hence, the Polish company could not be held to the standard of the collective agreement (paras 24-31). The freedom to provide services confirmed that reading. The minimum wage imposed by means of the collective agreement was an obstacle to the free provision of services by the Polish company. That obstacle was not justified by the needs to protect workers, the independence in the organization of working life by trade unions, or the balance of the host state's social security system, in essence because the collective agreement was not universally applicable in the host state (paras 37-42).

In Commission v. Luxembourg (posted workers), 2008 the Commission took issue with Luxembourg's subsuming a whole series of measures implementing Directive 96/71 under the public policy exception in this Directive. The Court stated that article 3(1) Directive contained an exhaustive list of matters in which each member state could prioritise its own rules and apply them to workers posted to its territory. The public policy exception in article 3(10), in turn, only concerned provisions that were so essential for the protection of the political, social, or economic order of the host state that they had to be applied to all persons in that state's territory and that there could be no derogation from them. The exception had to be strictly construed. Moreover, those provisions had to comply with the freedom of services (paras 24-33). That was not the case for several of Luxembourg's rules. The condition for posted workers to comply with all of Luxembourg's rules concerning written contracts of employment was not covered by the public policy exception, since a Community directive, viz. Directive 91/533, had imposed on each state certain requirements in this regards. The 'home' state thus already ensured compliance with those requirements and the worker was sufficiently protected. Luxembourg's rule failed to take that into account and deterred foreign undertakings from posting workers (paras 35-43). For the same reason, Luxembourg could not lawfully impose compliance with its rules on part-time and fixed-time work under the cover of public policy (paras 57-60). It could not lawfully be required that all rates of remuneration be auto- 
matically adjusted to the cost of living in Luxembourg based on the public policy exception, either. The list in article 3(1) already governed the aspect of the minimum wage. Luxembourg had failed to establish the prerequisite serious threat to one of the fundamental interests of society (paras 45-54). Collective agreements were only to be imposed as far as they were universally applicable (paras 64-67). Luxembourg's monitoring regime also lacked clarity in that it was uncertain whether it required prior notification (paras 78-80). The role of the ad-hoc agent to be designated in Luxembourg who held the documents required, finally, could be fulfilled by a worker posted to Luxembourg. In any case, in the absence of further justification it could only lawfully be required for the duration of the project for which the workers had been posted (paras 85-95).

In Commission v. Belgium (posted workers), 2009 the Commission initially challenged Belgium, because Belgium's regulation required a set of document to be provided when third country nationals were posted to Belgium. However, it turned out that Belgium's requirements were satisfied by the production of a form E 101, a posting certificate issued by the social security authority of the state of origin, or any other possible evidence. That, the Court held, accorded with the possibility established in case-law to require prior notice in case of posting of third country nationals (paras 12-9).

\section{Medical services}

With Smits, 2001 the Court began to develop the medical services case-law initiated in Kohll, 1998. In contrast to Kohll, 1998, Smits, 2001 concerned hospital services, i. e. intra rather than extra muros. The Dutch system was based on contractual arrangements between sickness insurance funds and hospitals. Benefits in kind were provided and a contractual hospital was then reimbursed by the fund concerned. Any treatment sought in non-contractual hospitals, including hospitals established abroad, was subject to prior authorization by the sickness insurance fund concerned. According to Dutch law that authorization had to be given when the treatment sought was in accordance with medical standards and medically necessary in the light of Dutch standards. The Court refused to limit the scope of the freedom of services to services provided extra muros. The freedom of services applied, although benefits were provided in kind. In case of hospital care abroad the patient usually had to advance payment and then claim the sum back from the fund. Flat rate payment under contractual arrangements in any event constituted consideration for services (paras 53-8). The authorization requirement on which reimbursement of cost incurred abroad depended amounted to a restriction, for most non-contractual hospitals were situated abroad (paras 62-9). While the grounds put forward in Kohll, 1998 to justify the restriction of services, viz. maintaining the financial balance of the system, a balanced service open to all, treatment capacity, medical competence, and satisfying planning requirements, did ultimately not prevail in that case, in Smits, 2001 those grounds won out for the authorization of intra muros treatment. With hospitals, cost and wastage had to be controlled and increasing demands for services had 
to be met with limited financial means; a high quality of services had to be assured (paras 72-81). However, the authorization criteria applied had to be based on international standards of science, with reimbursement of a specific treatment under the insurance systems of other member states being indicative of such standards; under no circumstance could the place where a hospital was established be a criterion. Yet a member state could lawfully limit reimbursement to specific treatments, e. g. by means of a list; and it was not necessary to extend reimbursement solely because other member states were more liberal. Medical necessity of the treatment abroad, that is whether the same treatment was available without undue delay in a contractual hospital, i. e. in the Netherlands, as a criterion was in order, though it was not to be used to prefer Dutch hospitals over hospitals in other member states. Finally, the standard case-law regarding authorizations requiring objective standards made public in advance and procedural guarantees and precluding any discretion of authorities had to be complied with (paras 83-106).

Müller-Fauré, 2003 again concerned the Dutch sickness benefit scheme, prompting the Court to reiterate in a first step what had been ruled for intra muros treatment in Smits, 2001. The Court spelled out, though, that the question whether treatment was available in the 'home' state 'within undue delay' was to be decided in the light of a specific patient's condition and situation (para. 90). The existence of waiting lists as such did not automatically mean that there was no 'undue delay' and, therefore, did not in itself justify a refusal to grant the authorization to seek treatment abroad (para. 92). In a second step, the Court in Müller-Fauré, 2003 held for extra muros treatment - which, as the Court admitted, was sometimes distinguishable from intra muros treatment only with difficulty (para. 75) - that a prior authorization requirement was contrary to the freedom of services. The grounds that prevailed in Smits, 2001 for intra muros treatment and justified the restriction of free movement of services failed to win out for extra muros treatment. There was no evidence that the financial balance of the system concerned was undermined, if the prior authorization requirement was abandoned (para. 93). Patients would not travel abroad in masses to seek medical treatment extra muros, either (para. 95). Mainly frontier regions were concerned and in practice doctors established abroad already had concluded agreements allowing the costs to be reimbursed (para. 96). The impact on social security systems based on benefits in kind would be limited, since inter alia article 22 Regulation 1408/71 already required such systems to be adjusted so that they allowed for reimbursement of the cost for treatment received abroad (paras 105 and 102). The member states still had the power to lay down the limits of the cost to be covered and the conditions to be met, such as the prior consultation of a general medical practitioner, provided they did so without discriminating or creating obstacles to the freedom of services (paras 106-7). The legislation of the state to the social security system of which the person concerned was affiliated continued to apply and determined the benefits and the cover 
available, in contrast to when article 22 Regulation 1408/71 was applied (para. 98).

Leichtle, 2004 added to that case-law. Mr Leichtle was a civil servant in Germany who received health cure in a spa in Italy. He had not waited for the outcome of court proceedings that arose over the authorization needed for such cure to be covered by the German social security scheme he was affiliated with. Instead he had gone on to have the treatment and had sought reimbursement afterwards. The German scheme covered the cost only if a medical report confirmed that the treatment abroad was absolutely necessary owing to the greatly increased chances of success of the cure abroad. The relevant spa had to be included in a list of spas recorded by the scheme. The dispute was about the 'ancillary' cost of the treatment only, namely the cost of travel, lodging, board, visitor's tax, and the cost of a medical report at the end of the cure. The Court ruled that the ancillary cost was closely connected or inextricably linked to the treatment which qualified as medical services. Whether the cost was covered or not influenced the decision where to seek services. The issue was, therefore, within the scope of the freedom of services (paras 31-6). The additional report required on the necessity of the treatment abroad was an obstacle to service provision, in contrast to the general criteria of eligibility. It applied only to services provided abroad and thus discouraged such services (paras 37-42). A state was, indeed, free in general to set objective, transparent, and non-discriminatory limits to the treatments covered. Yet an additional report was not necessary to ensure the financial equilibrium of the social security scheme or to guarantee treatment capacity or medical competence (paras 46-7). It was for the national court to determine whether the need for a spa to be registered in Germany to qualify for reimbursement had a deterrent effect (paras 49-50). In keeping with Vanbraekel, 2001 , if the person concerned had not awaited a court decision, but rather advanced the expenditures and the final outcome of court proceedings was that they were covered, the person had to be reimbursed (paras 53-8).

In Watts, 2006 the Court then examined the authorization required by the British national health system, which was funded by public finances and essentially provided health treatment free of charge, to seek treatment abroad in the light of the freedom of services. For the intra muros-treatment at issue in the case, the Court first confirmed that article 22 Regulation 1408/71 had to be interpreted congruently with the corresponding medical services case-law under the free movement of services, in particular as to the question of undue delay (para. 60; see above). Both article 22 and the freedom of services could apply concurrently (paras 46-8). Apart from that, the authorization to seek treatment abroad constituted a restriction of the freedom of services which applied even to a free of charge-system such as the British, because it was not required for treatment in hospitals affiliated with the British national health system (paras 97-8). While a prior authorization required for hospital treatment abroad was as such compatible with the freedom of services, each of the conditions under which the authorization was granted had to be tested against that freedom. As established 
by the case-law on authorizations, discretion by the authorities was ruled out; criteria had to be made public in advance; a decision had to be subject to procedural review and where necessary be based on expert opinions; and it had to include the reasons based on which it had been adopted (paras 114-7). Certain other factors, however, were not to be factored in, like a potential distortion of the regular order of priorities due to urgency as expressed in waiting lists or the facts that funds needed to change to cover the cost of the treatment abroad or that medical services had to be compared for the purpose of reimbursement. The member states could be required to adapt their systems to realize the internal market freedoms. Hence a mechanism for reimbursement had to be established (paras 118-22). As to the amount to be reimbursed, the Court found that an obstacle to the free reception of services could arise where the legislation of the host state did not provide for full cover of a specific treatment, while the treatment in the 'home' state was free of charge. In such a case, the 'home' state, in this case the United Kingdom, had to top up. It also had to reimburse the difference between the actual amount charged and the amount covered in accordance with host state legislation, though only up to the objective value of the treatment in the 'home' state. To establish that value the United Kingdom could orient itself by means of the amounts the British national health system charged foreigners for specific treatments they received in the United Kingdom (paras 131-3). As to the ancillary cost of travel and accommodation incurred because of the treatment received abroad, the Court found that such cost was only to be covered in so far as it was paid for in case of treatment within the United Kingdom. It was also possible to impose objective and transparent limits (paras 139-42). Beyond the limitations the case-law established for the authorization to seek treatment abroad further budgetary considerations could not be taken account of (paras 145-7).

In Stamatelaki, 2007 the Court further refined the medical services case-law. Greek law excluded the reimbursement of cost that arose from treatment in private hospitals abroad, save for children under the age of 14 . The national court asked the question exclusively with regard to the freedom of services. That is why the Court refrained from addressing article 22 Regulation 1408/71. The Greek sickness insurance scheme established a restriction of the freedom of services which applied to private and public hospitals alike (para. 22), as treatment in Greek private hospitals under contract or in emergency cases was covered, while treatment in private hospitals abroad was not (paras 26-8). The grounds of justification acknowledged in the medical services case-law applied in this case equally, but the Greek measure was disproportionate. Instead of a downright exclusion of reimbursement it would have been possible to grant reimbursement only for treatment that had been authorized previously or within certain limits, for instance in accordance with a scale of reimbursable cost. Moreover, the controls to which foreign hospitals were subject in other member states as well as the professional qualifications of doctors working in foreign hospitals guaranteed the quality of the services provided in those hospitals (paras 35-7). 


\section{Games of chance}

Anomar, 2003 confirmed the Court's gambling case-law established in the 1990s. Portugal subjected the operation of gaming and gambling machines to a licence requirement and restricted it to certain designated places, such as casinos. Several Portuguese companies challenged that regulation. The Court, after having admitted the case since the national court could be in need of an answer to exclude reverse discrimination in an otherwise purely internal situation (paras 39-42), found that all games of chance and gambling constituted economic activities (para. 47). The free movement of services was affected, because Portugal's rules addressed the operation of gambling machines as a service rather than their import - in the latter case the free movement of goods and the provisions on monopolies would have been applicable (paras 55-6 and 59-60). The indiscriminate restriction imposed by Portugal (paras 65-6) could be justified by the grounds developed in the case-law, i. e. the need to protect the consumer combined with the need to maintain order (73-4), while the proportionality of the restriction was to be assessed by the national authorities, which were entitled to disregard lower standards of protection set by other member states (paras 78-80 and 87).

Lindman, 2003 again concerned lotteries. Finland taxed the winnings from a lottery in Sweden in the hands of the winner, while winnings in Finnish lotteries remained tax-free. The Court reiterated that the freedom of services applied to lotteries. Finland drew a distinction based on where the lottery was organised and this distinction induced players to participate in domestic lotteries in which the winnings were not taxed. The taxes paid by the Finnish organizer of lotteries in Finland could not be likened to the taxes levied on the foreign lottery winnings of the winner (paras 21-2). The distinction was not justified, as no evidence proved that participation in foreign lotteries, in contrast to domestic lotteries, increased the risks inherent in gambling (para. 26).

In Liga Portuguesa and Bwin, 2009 the Court further refined that gambling case-law. Portugal reserved all games of chance, i. e. lotteries, betting, etc., including those provided via internet, to a single national public provider. Bwin was established in Gibraltar where it lawfully offered online games of chance, including sports betting based on football matches of the Portuguese football league. Bwin also sponsored that league as well as some football clubs. The Portuguese authorities fined Bwin. The Court examined only the freedom of services, since any capital movement was entirely secondary to the provision of gambling services (para. 47). The restriction in the prohibition to offer games of chance via internet was justified by the need to fight crime. Portugal was free to determine the level of protection required. The proportionality of Portugal's measure was to be assessed with regard to Portugal only. That Bwin lawfully offered services in one state did not necessarily imply that another state had to tolerate the provision of the same service. The aim to fight crime was pursued in a consistent and systematic way. Given that harmonisation had not taken place, it was appropriate to reserve the online offer of games of chance to a single nation- 
al provider which was under strict control of the state. In the domain of online gambling the risk of fraud was high, because the consumer did not enter into personal direct contact with the service provider. Moreover, the combination of sponsoring with the provision of gambling services in one and the same company created the risk of the outcome of sporting events being influenced. Hence, the restriction was justified (paras 60-71).

\section{Taxes}

In the 2000s, the Court was practically inundated with services cases having a tax dimension. In the following, the cases are described in roughly chronological order. Commission v. Portugal (flight tax), 2001 established that the freedom of services-case-law applied to taxes on air services. Consequently, the applicable Regulation 2408/92 on access to air routes had to be read in the light of that case-law (paras 21-2). Portugal had levied higher security and passenger services taxes on international than on domestic and regional flights. The obstacle to cross-border services thus created was not justified. Portugal had failed to demonstrate any difference in the services offered to passengers depending on whether their flight was domestic or international. While a special treatment for flights to the Portuguese Azores and Madeira would have been in order, the taxes in question were not designed to address that situation. Finally, to treat all flights equally in terms of taxation did not imply that the fees had to be raised for domestic flights (paras 27-36). In the same vein, the Commission in Commission $v$. Italy (departure tax), 2001 challenged the higher departure tax Italy levied on international flights. Italy did not dispute the violation of the freedom of services and the Court adjudicated accordingly.

De Coster, 2001 also dealt with taxes. A municipality in Belgium had introduced a tax on satellite dishes. That it was a local authority that had introduced the tax, according the Court, was irrelevant (para. 27). According to the Court's case-law, the free movement of services covered broadcasting of television signals. The tax only affected signals received via satellite, but not those received via cable. As many foreign television programmes could only be received via satellite dish, the tax dissuaded viewers in the municipality concerned from receiving services from abroad. It also hindered the activities of operators in the field of satellite transmission and gave broadcasters in Belgium an advantage (paras 31-5). The control of the proliferation of satellite dishes and thus the preservation of the quality of the environment - if acceptable at all as a ground for justification - did not compensate the restriction, since other less restrictive means would have been available, such as requirements as to the size and position of dishes (paras 37-8).

In Danner, 2002 Mr Danner, a German-Finnish dual national, voluntarily continued to pay contributions under a pension insurance scheme established in Germany when he moved to Finland. However, Finland refused to allow him to deduct the contributions he continued to pay from his taxable income in Finland to the same extent contributions paid to a voluntary pension insurance scheme 
established in Finland would have been deductible. According to the Court, the freedom of insurers to offer the service of voluntary pension insurance (paras 25-7) was restricted, since residents of Finland were deterred from taking out policies with insurers established abroad and the latter from offering them in Finland. Tax relief was an important consideration in the decision to take out a voluntary pension insurance policy (paras 30-1). The cohesion of the Finnish tax system, viz. the Bachmann, 1992-ground, failed to justify the restriction, as under Finnish law the income eventually resulting from voluntary pension insurance would be taxable in Finland if the person concerned was resident there, regardless of whether contributions had been deducted previously or not. The double taxation convention with Germany did not alter that assessment (paras 35-41). The need for effective fiscal supervision did not justify the restriction, either, given Directive $77 / 799$ on mutual assistance and the possibility to ask the taxpayer for documentation (paras 48-52). Finally, the aim of preventing the reduction of tax revenue was not a suitable ground to justify a restriction (paras 54-6).

Taxation in the framework of pension insurance was also at issue in Skandia and Ramstedt, 2003. In this case, a Swedish company had taken out a pension insurance policy for the benefit of an employee with a company established in another member state. The Swedish tax authorities refused to deduct immediately the contributions the employer paid under that policy, because Swedish law allowed immediate deduction only if the insurer was established in Sweden. If it was established abroad, premiums paid could essentially be deducted only once the pension was paid out. According to the Court, Swedish tax law unlawfully restricted the freedom of insurers established in other member states to provide services in Sweden. That freedom applied, because the premiums the employer paid constituted the consideration for the service the employee received (paras 22-4). It was restricted, because foreign insurers were dissuaded from offering pension policies in Sweden, as were Swedish employers from taking out policies with foreign insurers (paras 27-8). The cohesion of the Swedish tax system was not in peril, because an employer which had taken out a policy with an insurer established abroad did not benefit from any compensatory measure that set off the disadvantage suffered, namely the delayed deductibility. The pension paid out was subject to income tax in the hands of the employee at the same time and in the same way irrespective of where the insurer was established (paras 34-7). Again as in Danner, 2002, Directive 77/799 on mutual assistance and proof furnished by the taxpayer guaranteed the effectiveness of fiscal supervision (paras 41-5). Further, the need to preserve the tax base could not justify the Swedish compensatory tax approach (paras 51-3). A final ground Sweden argued was rejected by the Court, in essence because the argument was hardly understandable at all (paras 57-8.)

Gerritse, 2003 dealt with the direct taxation of income in the light of the freedom of services. Mr Gerritse was resident in the Netherlands where he earned around 55'000 German mark. He went to Germany to perform as a drummer. 
For this performance he gained a little more than 6'000 mark, while he incurred expenses of about 1'000 mark. The German authorities taxed this income at the source at a rate of 25 per cent and refused to allow deduction of the expenses. Had he been resident in Germany, roughly the first 12'000 mark of income would not have been taxable at all, but his income would have been subject to progressive taxation at the source and expenses would have been fully deductible. Mr Gerritse could not request taxation as a resident for two reasons, namely he earned more than 12'000 mark abroad and he did not earn more than 90 per cent of his income in Germany. The Court examined the situation from the angle of the free movement of services, because Mr Gerritse was not established in Germany. First, the free movement of services ruled out the non-deductibility of business expenses, because they were connected to the generation of the earnings. Residents and non-residents were, therefore, in a comparable situation and the consequent discrimination was precluded (paras 27-29). Second, with regard to the taxation at the source at a flat rate of 25 per cent, the Court enquired into whether the difference in the situations of residents and non-residents was such to make it possible to disregard the discrimination (para. 47). The 12'000 mark tax-free allowance granted solely to residents could, according to the Court, lawfully be reserved to residents, in particular since it was possible for those who earned more than 90 per cent of their income in Germany to be treated like residents. Moreover, the Netherlands granted a similar tax-free advantage on income taxable in the Netherlands (paras 48-52). As to progressivity, the Court explained that the Netherlands also applied a progressive tax rate after having integrated the income gained abroad. Thus, the situation of residents and non-residents in Germany was comparable in that regard and, consequently, a higher tax burden for non-residents would be precluded. To determine whether the tax burden was indeed higher the national court had to add the net income 6'000 mark minus expenses - to the tax-free allowance - 12'000 mark - and then see whether the application of the progressive table for residents resulted in a lower tax rate than the 25 per cent-rate generally applicable to non-residents (paras 53-4).

In Stylianakis, 2003 the Court invalidated Greece's distinction in the passenger tax on flights. Twice the amount of tax was levied in case of flights covering a distance of more than 750 kilometres than in case of those covering a shorter distance. All flights covering the shorter distance, bar one, were domestic. This fact, according to the Court, made the free movement of services more difficult. That freedom applied because it expressed specifically the prohibition of discrimination of Union citizens (paras 18-20). It was applicable in the transport sector where it was implemented by Regulation 2408/92 on access to air routes (para. 24). Even if the tax constituted consideration for services, passengers of international flights did not require twice as many services as passengers flying domestically (paras 25-8).

In Commission v. France (fixed levy), 2004 natural persons who took out certain contracts, such as debt instruments or deposits, with persons established in 
France could opt for a fixed levy at the source on the proceeds from those contracts rather than the taxation of the proceeds as regular income. That option was not available for contracts concluded with persons established abroad. The Court found that the services offered by foreign companies became less attractive, because they could not offer the fixed levy option. Service recipients were, consequently, discouraged from concluding contracts with foreign service providers. That the advantage the fixed levy offered was in some circumstances minor was irrelevant. Service recipients usually only opted for it when it was advantageous (paras 22-5). The effectiveness of fiscal supervision and the prevention of tax avoidance did not justify a presumption of such a general nature as that applied by France. Proportionality was crucial when a national rule excluded trans-border transactions from its scope altogether. The simplicity of the French approach and the administrative difficulties involved in applying the fixed levy to foreign service providers were not valid grounds of justification. Directive 77/799 on mutual assistance was sufficient to guarantee cooperation, any banking secrecy notwithstanding. As an alternative, moreover, France could require foreign service providers to file a voluntary annual declaration (paras 27-33).

In Viacom, 2005 the Court validated a tax an Italian municipality levied on advertisements displayed in the public space of the municipality. The tax, the level of which was modest, was levied from the agent providing the service of displaying the ads for a third person. The Court did not find a restriction. The tax applied equally to all agents providing the service, no matter where the service receiver was established or where the product or service advertised originated from. The level was modest. Moreover, it only applied to ads placed outdoors (paras 37-8).

Fournier, 2005 dealt with a tax credit for research expenses in France. According to French law, expenses made to conduct research gave rise to a tax credit as long as the research was conducted in France. In the judgment of the Court this approach violated the free movement of services. The cost of research services provided by a company established in another member state was not tax creditable for the service receiver established in France, while in case the service provider was established in France they were. That differentiation based on the places of service provision and, indirectly, establishment was contrary to the freedom of services, despite the principle of fiscal territoriality (paras 15-8). It was not justified by the cohesion of the tax system for lack of a direct link between the corporation tax and the tax credit for research expenses. While the promotion of research basically was a ground to justify a restriction, the French measure ran directly counter to the Community's policy aim of encouraging research within the area of the internal market. The effectiveness of fiscal supervision did not prevail, either. A taxpayer had to have the possibility to prove that research conducted abroad had given rise to relevant expenses (paras 21-5).

In Mobistar, 2005 two municipalities in Belgium levied taxes on mobile telephony antennae and other communication infrastructure. According to the 
Court, while those taxes added additional cost to the provision of services, they affected in the same way all service provision, no matter whether across the border or within Belgium. Such measures were outside the scope of services. Moreover, the taxes applied indistinctly and affected the tariffs of all service providers equally. There was no cumulation of local taxes that had the effect of compromising the freedom of services (paras 31-4).

In Commission v. Finland (VAT), 2006 the Court in the light of the relevant value added tax directive invalidated Finland's requirement for those not established in Finland to appoint an agent there when value added tax became payable in Finland. Given that the value added tax directive regulated the matter exhaustively, there was, according to the Court, no need to apply the freedom of services (para. 55).

Scorpio, 2006 concerned certain German tax rules which obliged certain service receivers established in Germany to retain at the source the income tax a service provider established in the Netherlands owed in Germany as a consequence of the service provision, in this case artistic and cultural performances subject to income tax in Germany. Failure to retain the tax resulted in the liability of the service receiver vis-à-vis the German state. Business expenditures the service provider had incurred could not be deducted right away from the amount retained, but only in a subsequent procedure. The benefits due under the double taxation convention between the Netherlands and Germany could only be claimed, if a German office had certified that the conditions to be fulfilled were met. The duty to retain taxes did not apply in case the service provider was established in Germany. The case at issue concerned specifically a Dutch-German cooperation in the organization of concerts, as a result of which the German company involved incurred liability for having failed to retain the tax due at source. The Court ruled that the duty to retain the tax due and the liability in case of failure to do so constituted restrictions of the free movement of services, because service receivers were deterred from calling on providers established abroad. However, the Court found the restrictions legitimate, appropriate, and proportionate, and thus justified by the need to collect income tax effectively (paras 33-8). The Court pointed out, though, that the facts had taken place before the Maastricht Treaty had entered into force. Moreover, no legal instrument governed mutual administrative assistance for debt recovery between the Netherlands and Germany (para. 36). In contrast, expanding on Gerritse, 2003, that expenditures directly connected to the service provision were only refunded in an ex post facto procedure amounted to an unjustifiable restriction. The service provider had to have the possibility to report expenses directly related to the service, but only those expenses - though a member state was free to allow that other expenses were taken account of (para. 51) - to the service receiver who would then have to take them into account (paras 42-8). As to the certificate attesting that tax needed not to be retained owing to the double taxation convention, the Court held the restriction of the freedom of services inherent in the requirement to obtain such a certificate to be justified. The service receiver could 
only be released from the obligation to retain the tax at source once it was definitely certain that no tax was due, else the proper functioning of the procedure for taxation at source was compromised (paras 56-60). Finally, when the service provider was a third country national the freedom of services was not applicable, irrespective of whether the service provider was established in a member state or not and whether the service was provided within the Community (paras 66-8).

In Commission v. Belgium (contractors), 2006 an approach was at stake that was quite different from that in Scorpio, 2006. Belgium required all those in the construction industry who contracted with service providers who were not registered in Belgium to withhold a certain amount of the payment due under the contract to secure possible tax debts of the non-registered contractor. Moreover, both contractors became jointly liable for tax debts owed by the non-registered contractor in Belgium as a result not just of the contract they had concluded, but more generally of any activity in Belgium. According to the Court, the issue of the registration of the contractor could be separated from the withholding/liability obligations (paras 13-4). Each of those obligations constituted a restriction of the freedom of services for they deterred service provision. It was irrelevant that the joint liability applied indistinctly to all providers who were not registered in Belgium, for it was sufficient, so the Court, that it impeded access to the Belgian market (paras 30-2). The obligations were not justified by the prevention of tax fraud. The duty to withhold a part of the payment due under a contract was too general to combat fraud and failed to take into account the specific circumstances of each case. In essence, not everyone who had not been registered in Belgium committed tax fraud. Nor was everyone liable to pay tax in Belgium in the first place. Less restrictive measures, such as a system to exchange information with the tax authorities on such contracts, would have been available. The joint liability could also be replaced by less restrictive means, such as the possibility to prove tax compliance. Moreover, the withholding obligation and the joint liability applied cumulatively (paras 34-41).

Centro Equestre, 2007 concerned taxation of income generated through services provided in Germany. Centro Equestre was a company established in Portugal which provided certain artistic services in Germany. Those services gave rise to income which was subject to restricted taxation in Germany pursuant to the applicable double taxation convention. The tax was deducted at the source. Centro Equestre then claimed repayment of the tax corresponding to the amount of the operating expenditures incurred in providing the services in Germany. According to German law, only those expenditures could be taken into account that were made to provide the services subject to taxation in Germany. Moreover, expenditures were only taken account of, if they amounted to more than 50 per cent of the income taxed. For persons subject to unrestricted taxation in Germany, such a limitation did not apply. According to the Court, in a situation where residents were taxed on their net income, it followed from Gerritse, 2003, Scorpio, 2006, and from territoriality as established in Futura, 1997 that it was consistent with the services freedom to allow non-residents to deduct solely those 
expenditures that were directly connected with the provision of the services. Such expenditures were those that were inextricably linked to the provision of the service concerned, such as travel and accommodation cost, irrespective of where and when they had been incurred (para. 25). However, to require that the amount of expenses added up to half of the income, raised an obstacle to the freedom of services which was not justified by the need to avoid that costs were deducted twice. The German mechanism of information exchange as well as Directive 77/799 on mutual assistance prevented double deduction. Moreover, Portugal set off taxes paid in Germany against taxes due in Portugal. It was therefore possible for Portugal to examine which costs had been deducted in Germany (paras 29-37).

In Commission v. Denmark (insurance taxation), 2007 the Court held that Denmark's requirement that insurers be established in Denmark for income tax relief to be applicable violated the freedom of services (see above). In Commission v. Belgium (tax matters), 2007 the Commission challenged several of Belgium's tax rules before the Court. The Court found that the following rules amounted to obstacles to the free movement of services for the internal market as well as the European Economic Area. (i) Supplementary contributions employers made to pension and life assurances could only be deducted for tax purposes, if the fund or undertaking with which the assurance had been taken out was established in Belgium. (ii) Tax reductions for long-term savings were only granted, if the contributions were paid to funds or undertakings established in Belgium. (iii) A tax was levied, when capital or surrender values which had been built up through contributions by an employer were transferred to a fund or insurance undertaking established outside Belgium. (iv) Insurers established abroad had to have a personally liable representative in Belgium to ensure payment of taxes due as a result of insurance contracts (paras 39-46). Belgium only argued justification for the last rule (iv) on the ground that it was necessary to ensure collection of taxes. The Court rejected that argument, because Belgian law itself knew less restrictive measures (paras 52-7). In addition, the limitations of tax deductions and reductions for long-term savings (i and ii) as well as the tax levied in case of transfers (iii) violated the free movement of persons and, in case of rule (iii), the free movement of Union citizens, as did a further rule according to which a tax was triggered when certain savings were forwarded to an insurance institution established outside Belgium (paras 61-76).

In Gootjes-Schwarz, 2007 Germany refused tax relief to a married couple for school fees charged by a private school their children attended in Scotland. Had the school been approved in Germany, which was the case only for schools established in Germany, tax relief would have been granted. The Court held that the free movement of services was breached. The freedom covered education provided by private schools when such schools were mostly financed by private funds. Those funds need not necessarily have stemmed from parents or pupils. It was irrelevant whether schools in Germany provided services in the sense of the freedom of services. What mattered was that the school in Scotland provided a 
service (paras 34-45). The Court found an obstacle to the freedom of services in the refusal to grant tax relief on the ground that the school was established in another member state. Service receivers were deterred from seeking services abroad, service providers were hindered in providing them (paras 64-7). The justification of the discrimination failed. The German measure did not constitute a subsidy for schools, but tax relief for taxpayers (paras 70-1). Even if it were arguable based on Bidar, 2005 that it needed to be avoided that tax relief for school fees became an unreasonable burden for the state concerned so that the overall level of aid that state could grant would be reduced and even if the fact that the reduction of tax receipts were a ground capable of justifying a restriction, Germany could have applied a less restrictive measure. Instead of automatically excluding tax relief for foreign school fees, Germany could have limited the amount of private school fees for which tax relief was granted for all private schools, irrespective of where they were established, based on objective criteria (paras 72-3 and 76-81). In as far as the freedom of services did not apply, so the Court, Union citizenship had to be examined (paras 34-5). Children who were Union citizens and went to another member state to attend a private school exercised the right to move freely flowing from Union citizenship. There was a difference in treatment between taxpayers depending on where their children attended school, resulting in a disadvantage for the children. In the same vein as with the freedom of services Germany's measure was disproportionate under citizenship. Thus, even where a school was not covered by the freedom of services, Germany's refusal was precluded (paras 90-8). In Commission v. Germany (private schools), 2007, handed down on the same day as Gootjes-Schwarz, 2007, the Court addressed the same German legislation. The substance of the judgment was largely identical to Gootjes-Schwarz, 2007, save that the Court added that the German legislation also violated the free movement of workers and the freedom of establishment of self-employed persons when those freedoms were applicable in certain particular constellations. The freedom of establishment of private schools was not violated though (paras 114-22).

In Jundt, 2007 a university teacher who was subject to taxation in Germany taught a university course in France. He received an expense allowance. Germany, however, refused to factor out that allowance from taxable income, although it would have been had the expense been paid by a German university. The Court ruled that the situation was within the scope of services. Although a public university had granted the expense allowance and courses taught within publicly financed educational institutions as such were not services, the freedom of services applied in that case, because the university had called for and paid remuneration for the services of a natural person on a secondary basis. That the service was quasi-honorary and the remuneration hence did not include a profit was irrelevant. It was sufficient when the service was provided for some reward at all (paras 31-5). Teaching at university was not connected to the exercise of official authority (paras 36-8). The refusal to grant a tax concession in case of teaching abroad amounted to a restriction of the freedom of services (paras 
53-4). It was not justified by the promotion of teaching and research and development, even if that were a ground suitable for justification, for the measure essentially discouraged teaching abroad, while the Community encouraged cooperation in education. The free movement of Union citizens in educational matters was particularly important, as established in Morgan, 2007, and the German measure infringed the freedoms of teachers without necessity, given that the aims of Germany's educational policy could be attained without excluding the tax exemption (paras 57-64). The direct link required for the cohesion of the tax system to justify a restriction was missing. The link between the tax exemption and the contribution to public teaching was too general and indirect (paras 66-70). Finally, in spite of the member states' powers to organize their education systems they were required to comply with the freedoms, in particular with the tax exemption being a fiscal, rather than a measure organizing the educational system (paras 81-8).

In Jobra, 2008 the Court addressed a tax premium Austria's tax law afforded to those who invested in goods that were possibly then leased out, provided that those goods were primarily used on Austrian territory. Jobra was a company established in Austria that invested in lorries and leased them to a company in Germany which was part of the same group. Jobra's claim for the tax premium was rejected, because the lorries were mostly used in Germany. That the tax premium was only granted, when leased goods were used in Austria, the Court held, discouraged the leasing out of goods to persons in other member states. The restriction thereby established violated the freedom of services (paras 22-6). It was not justified by the balanced allocation of powers of taxation, irrespective of whether all conditions tied to that ground were met, because the income from such leasing agreements was taxable in Austria (paras 32-3). As a direct link did not exist between the premium granted to the lessor and the subsequent taxation of the income of the lessee, the cohesion of the tax system did not justify the restriction, either (para. 34). The prevention of abuse through the establishment of wholly artificial arrangements also did not justify the restriction, for the premium did not target such arrangements. The rule relied on a general presumption of abuse, and in particular proof could not be brought showing that a specific transaction was not abusive (paras 36-38).

In X and Passenheim, 2009 the regime the Netherlands applied in case of undeclared taxable assets or income came before the Court. In case a taxpayer had failed to declare assets situated in the Netherlands, such as a bank account, under Dutch law taxes that would have been due were recovered for the five years preceding the assessment. In case of assets situated in other member states the recovery period was twelve years. The fine imposed in case of concealment corresponded to that recovery period. Consequently, it was higher when the assets were situated abroad. The Court judged that the distinction drawn on the basis of where the assets were situated had the effect of restricting the freedom of services and the freedom of capital, notwithstanding the taxpayer's possibility to declare assets. Receivers of financial services were dissuaded from seeking ser- 
vices abroad (paras 34-9). The effectiveness of fiscal supervision and the prevention of tax evasion could justify the restriction (paras 45-6). The measure contributed to the achievement of those aims and hence was suitable (paras 49-52). While the period did not reflect the time needed for the authorities to find and tax the tax items concerned, a member state was not required to adapt its law to the law of other member states, in particular those with banking secrecy (paras 57-61). However, a distinction had to be drawn. (i) In the case of taxable items of which the authorities did not have any knowledge, because the taxpayer concealed them, a longer recovery period of twelve years in case of assets situated abroad was justified. The period in that case reflected the fact that the longer the period was the higher the chances were of discovering concealed assets. The instruments on exchange of information, namely Directive 77/799, could not apply in that case, because the authorities did not know about the items (paras 63-73). (ii) In the case of tax items the authorities knew about, the period of recovery merely reflected the time needed to obtain the necessary information. Thus, the recovery period had to be adapted to the circumstances. Directive 77/799, a double taxation convention, automatic information exchange, banking secrecy in another member state - all those were factors that could influence the time needed to obtain the information necessary to assess the taxes payable. The recovery period therefore needed to be set in function of those factors, else the restriction was disproportionate (paras 74-5). Apart from that, the difference in the amount of the fine imposed depending on whether assets were situated abroad merely reflected the length of the recovery period and as such it was justified (paras 82-5).

In Commission v. Spain (lotteries), 2009 Spain's tax law drew a distinction. On the one hand, there were certain organizers of games of chance established in Spain. The gains made in games of chance organized by them were exempted from income tax, since they presumably pursued certain social purposes. On the other hand, other organizers of games of chance established in Spain as well as all organizers established abroad - irrespective of the purpose they pursued - did not benefit from such a presumption. The winnings made in games of chance organised by them were not exempted from income tax in Spain. The Court decided that the organizers established abroad that pursued social purposes - and only them - and those Spanish organizers that could distribute tax-exempt gains were in comparable situations. Hence, Spanish law was discriminatory in that it refused to treat the two organizers in the same way, notably by refusing the foreign organizers the benefit of exempting gains made in their games from income tax in Spain (paras 33-5). The restriction, as it was discriminatory, was not justifiable by the grounds recognized by the case-law which were not expressly mentioned in the Treaty (paras 36-7). More specifically, the grounds Spain argued did not prevail. Even assuming that the prevention of money laundering came within the public policy derogation, a general presumption that games of chance organized abroad were connected to money laundering could not lawfully be applied. As the measure encouraged participation in games of chance it did not pursue the aim of public health protection in a coherent and systematic way, 
even assuming that preventing gambling addiction, the spread of which was not proven, came within the public health derogation. Since the exemption was applicable to winnings made in all games organised by the privileged organizers, it could not be argued that the measure served to channel betting towards less addictive forms of games of chance. The financing of activities with a social purpose was not a ground in itself. The protection of consumers as well as the social order were not mentioned expressly by the Treaty and the measure did not have any direct link to administrative measures to protect consumers, much like it encouraged participation in games of chance (paras 39-46).

Presidente, 2009 concerned a tax that was levied at the occasion of stopovers of pleasure boats and airplanes in Sardinia. The tax was only payable by persons who did not have tax domicile in the region. Since the tax was not technically levied on transports of persons such as tourists, the Court first established that the tax had an indirect impact on the provision of cross-border services, for instance when the operator of a boat rented it out to tourists who then harboured in Sardinia and on that occasion received services (paras 24-8). The tax supplied those having tax domicile in the region with an advantage (paras 29-32). The Court confirmed that residents and non-residents were usually not in a comparable situation with regard to direct taxation. However, in assessing comparability the specific characteristics of the tax levied had to be examined. In the case at issue, the taxable event was a stopover by boat or plane in Sardinia. There was no objective difference in the situations of persons liable or not to pay the tax. The impact on the environment was the same, irrespective of whether the taxpayer had domicile in Sardinia or not. That persons domiciled in Sardinia contributed to the protection of the environment through the regular taxes they paid, like income tax, while others 'behave[d] like environmental 'free-riders" (para. 33), was irrelevant for the comparison to be made, since the regular taxes were not of the same nature and did not pursue the same purpose as the stopover tax (paras 34-8). The same considerations led the Court to reject justification. The pollution was the same regardless of whether it originated from persons domiciled in Sardinia or elsewhere. The need to maintain the cohesion of the tax system did not provide any justification, either, for lack of a direct link between the advantage, i. e. the exemption from the stopover tax, and the disadvantage, i. e. payment of income tax (paras 44-8). In conclusion, while a tax on stopovers as such was legally possible, the way it was implemented contravened the freedom of services (para. 43).

\section{Private security firms}

Commission v. Belgium (security firms), 2000 began the case-law on private security firms in the 2000s. The Commission challenged certain prerequisites for foreign private security firms to operate in Belgium. After having found that the official authority exception did not apply for lack of a direct connection (paras 24-6), the Court rejected each of the Belgian conditions. A place of business in Belgium could not lawfully be required, since private security firms as such were 
not a genuine threat to one of the fundamental interests of society within the sense of the public security exception, which, in any event, could only be relied upon to refuse entry or residence to individuals, not to exclude an entire business sector from a treaty freedom (paras 27-30). To require a prior authorization in Belgium went beyond what was necessary to supervise such firms and failed to give due regard to 'home' state regulation (paras 35-8). Security guards could moreover not lawfully be required to have a specific identification card, given that service providers in general had to have an identity card when entering another member state (paras 39-40). Apart from those violations of the freedom of services, the Court also found that a residence requirement for managers and staff violated the free movement of persons, as less intrusive measures existed to obtain the information needed about the person concerned (paras 31-4). The Court followed up in Commission v. Italy (private security guards), 2001 confirming that a general nationality condition was not to be applied to bodies and individuals providing private security services. The Court also ruled that the official authority exception was not pertinent, since the powers of private security guards to arrest people did not go beyond the powers of ordinary citizens (paras 18-21). Besides, a nationality condition also restricted the free movement of workers. The public service exception did not make up for that restriction, given that the security entities concerned were private (para. 25.)

Commission $v$. Netherlands (private security), 2004 largely confirmed the private security firms case-law. The Netherlands failed to take into account 'home' state legislation, with which a company already complied, with the Dutch requirement for firms and managers to have an authorization (paras 17-20). A certificate issued by the Dutch authorities could not lawfully be required, either, since an identification card was needed to enter the Netherlands anyway. Possible exemptions from the authorization requirement did not change that assessment, as long as they were subject to the authorities' discretion (paras 27-31). In Commission v. Spain (private security), 2006 the Court confirmed what had been established in Commission v. Portugal (private security), 2004 (see the freedom of establishment, above). Previously, the Court had already invalidated certain conditions contained in Spanish law in Commission v. Spain (private security guards), 1998. The Court added several points, though. A minimum share capital for private security firms could not be justified by the prevention of terrorist threats for lack of a direct connection (paras 36-7). Spanish legislation requiring the lodging of a security deposit with a Spanish bank was disproportionate in that it failed to take into account similar guarantees already provided in the 'home' state (paras 41-4). The minimum number of employees of private security firms Spanish law required went beyond what was needed to guarantee a certain level of security, except in the case of transports of explosives (paras 48-51). To require a fresh authorization for each staff member in the host state, without taking into account compliance with 'home' state regulation, went against the grain of the freedom of services and establishment (paras 55-7). Fi- 
nally, private detectives were a regulated profession under Directive 92/51 for which Spain had failed to establish a system of mutual recognition (paras 64-65).

The Court in Commission v. Italy (private security), 2007 rejected as incompatible with the freedom of services, and partially with the freedom of establishment, a series of conditions Italian law required private security undertakings to meet. (i) The obligation to swear on oath of allegiance to the Italian Republic hindered access to the Italian market and was more easy to fulfil for Italian nationals. Private security undertakings did not exercise official authority, as established previously. Neither did they constitute a threat to the public order which had to be countered by an oath of allegiance (paras 36-51). (ii) An authorization of limited territorial validity - thus an authorization that had to be requested in each of the 103 provinces in Italy - failed to take into account the requirements undertakings already complied with in the 'home' state and therefore violated the freedom of services (paras 58-64). (iii) The limited territorial validity and the account taken of, for the purpose of assessing whether a licence was to be granted or not, the number and size of private security undertakings already operating in a specific region, violated the freedom of services and establishment. The needs to supervise undertakings effectively and to prevent infiltration by local criminal organizations did not prevail, for less restrictive measures were available, such as administrative controls coupled with a general authorization and sanctions if necessary. Moreover, foreign private security undertaking did not generally intend to usurp the role of the public authorities (paras 74-8). (iv) The freedom of services also ruled out a condition to have an establishment in each region. Effective supervision did not depend on a place of business (paras 84-7). (v) Staff members could not lawfully be required to obtain individual fresh authorizations, either (paras 93-4). (vi) The approval of the authorities needed for any change in the number of staff violated access to the market in a way contrary to the freedom of services and establishment. It was not necessary to guarantee effective supervision (paras 100-4). (vii) The lodging of a guarantee with an Italian depositor, required for each province, failed to factor in 'home' state regulation, and was thus unnecessary for effective supervision (paras 109-14). (viii) The prices for the services which were fixed by the Italian authorities, despite the margin for variation applied, finally, deprived foreign competitors of possibilities to compete effectively and to factor in cost which Italian undertakings did not incur, resulting in a violation of the freedom of services (paras 124-7).

\section{Leased cars}

The Court dealt with leased cars in a number of judgments during the 2000s. Cura Anlagen, 2002 dealt with certain requirements Austria imposed in relation to such cars. A company established in Germany concluded long-term leasing contracts with customers in Austria. The Court assessed Austria's requirements in the light of the free movement of services, for the lease of a car constituted a service (paras 18-20). Austria could lawfully require cars leased from companies 
established abroad to be registered in Austria, if the cars were primarily used in Austria, for Austria retained that power for lack of harmonisation in the Community. The registration, moreover, was the natural corollary of the power to tax vehicles (paras 37-43). However, to require registering a car in Austria within three days after arrival was excessive. The period was too short to comply with the freedom of services (paras 46-7). The lessor could likewise not be expected to have an establishment in Austria in case the lessee was not authorized to register the vehicle in his or her own name. It would equally satisfy the need to identify the responsible person in case of an accident, if the lessor simply had to communicate the details of the lessee upon registering a car in its own name in Austria (paras 48-51). Austria was only allowed to insist on insurance in Austria within the confines of Directives 2000/26 on civil liability insurance for vehicles and third non-life insurance Directive 92/49 (paras 53-6). Similarly, a roadworthiness test could be required only in accordance with the corresponding Directive 96/96, since such a test constituted an obstacle in need of justification in terms of road safety. In particular, tests to be taken in Austria could not again examine requirements that had been tested previously abroad, though if the vehicle had been used in the meanwhile, a check for deterioration was in order (58-63). A tax based on the fuel consumption of the car concerned, in turn, was justified in the light of environmental protection, provided that the tax varied according to the duration of the leasing (paras 68-9).

In Leroy, 2006 the Court confirmed for the freedom of services what had been established in Nadin and Durré, 2005 for the freedom of establishment, namely that registration of a vehicle leased in one member state was lawfully required by another member state where the lessee was resident when the vehicle was used on a permanent basis in the latter state (para. 14). In keeping with that case-law the Court added in Van de Coevering, 2006 that a vehicle tax levied on vehicles leased abroad was, as a restriction of the freedom of services (para. 21), subject to the same condition. However, the Court reiterated, a member state could still levy a tax on vehicles which had been leased abroad - even if they were not used permanently in its territory - if further justification existed and, in particular, the amount levied was proportionate to the time during which the car was used in its territory (paras 28 and 30-2). In Ilhan, 2008 the Court re-applied that case-law on cars leased and registered abroad. A tax imposed at the occasion of registration was only lawful when the leased car was intended to be used, or in fact used, in the host state. Further, the tax had to be proportionate to the use made of the car in the host state, notably the duration of the leasing contract and the nature of the use made of the car (paras 21-4).

\section{Maritime transport}

Maritime transport occupied the Court in a few decisions during the 2000s. Analir, 2001 concerned maritime cabotage to, from and between islands. Spain required of maritime transport service providers to obtain an authorization which was subject to the service provider being in good financial standing, i. e. 
having no outstanding tax or social security debts. Spain also imposed certain public service obligations on providers of maritime transport from, to and between Spanish islands. Concurrently, Spain concluded some public service contracts with transporters as to the same routes. The Court confirmed that Regulation $3577 / 92$ on maritime transport implemented the freedom to provide maritime cabotage services and went on to apply the freedom of services in that context (paras 17-20). An authorization requirement was not mentioned by the Regulation. It constituted a restriction of the freedom of services (paras 22-4) which could basically be justified by the need to ensure an adequate level of transport to and between islands. However, a real public service need had to be demonstrated in the sense that no adequate level of transport would be provided under market conditions and a declaration ex post facto had to be shown to be insufficient. Relying partly on free movement of capital case-law, namely Bordessa, 1995 and Sanz de Lera, 1995, the Court also ruled that an authorization requirement would have to meet certain other conditions. The criteria applied had to be objective and specified in advance so as to circumscribe the discretion of the authorities and exclude arbitrary decisions. Legal remedies also had to be available (paras 27-39). Within those confines, the financial standing of a service provider could serve as a criterion, particularly since the Regulation relied on the capacity of a company to provide a service (paras 47-50). The Court did not object, either, to the method of concluding a public service contract concurrently with imposing public service obligations with regard to one and the same route, provided a real public service need had been established and necessity as well as non-discrimination were respected (paras 60-70).

Commission v. Italy (passenger tax), 2002 confirmed the case-law as to passenger transports. A passenger tax which was only levied on ship transports to and from ports in other member states, but not in case of transports between two ports in Italy, violated the freedom to provide services, as laid down for maritime transport in Regulation 4055/86. (Italy had not disputed the violation.) Sea-Land, 2002 also dealt with the freedom of services in the context of Regulation 4055/86. A Dutch company and a US company challenged a charge the Netherlands imposed on those seagoing ships that exceeded a length of 41 meters. The charge was supposed to compensate for the specific services such large ships needed. However, ships that only used inland waterways were not subject to the charge. The Court found that the charge was not indirectly discriminatory, since the situations of inland water vessels and seagoing ships were objectively different and not comparable (paras 33-7). The obstacle to the provision of services which the charge nevertheless raised was justified, since the services performed in exchange for the charge contributed to public security. Moreover, the amount charged was commensurate with the cost of the services received (paras 38-43).

In Naftiliaki, 2002 the dues imposed on passenger transports between Rhodes in Greece and Turkey were challenged under Regulation 4055/86. Those dues were higher than the dues imposed in case of purely domestic transport or trans- 
port between Greece and other member states. The Court confirmed that higher dues on journeys to and from ports in other member states than on purely domestic journeys were precluded by the freedom of services as implemented by the Regulation. That ruling applied even if a due was payable by the passenger, for it increased the cost of the journey. Since the Regulation had rendered applicable the entire freedom to provide services to maritime transport - thus precluding restrictions - and then extended it to cover traffic with third states as well, higher dues on journeys to and from Turkey than on journeys within the Community were precluded (paras 19-22). The Court also clarified that the dues imposed could only vary depending on the cost of the service a passenger received. For lack of objective justification, dues were not to be higher the further a destination was away, either (paras 26 and 28).

Commission v. Greece (cabotage), 2004 then came back to maritime cabotage under Regulation 3577/92 which had already been at issue in Analir, 2001. Greece required those who wanted to provide maritime cabotage services to furnish a certificate issued by the flag state that proved that the ship was authorised for cabotage services. Moreover, Greek law designated the Peloponnese as an island, thus rendering applicable the provisions of the Regulation as to transport to and from islands. The Court held that the certificate to be provided constituted a restriction of the freedom of services which was not clearly excluded by the Regulation (paras 30-1). The Court did not find any less restrictive approach to ensure that the ship concerned complied with flag state regulation and thus validated the Greek requirement (paras 34-5). The Peloponnese could not be designated as an island, though, essentially because it was only separated from the Greek mainland by a narrow man-made canal (paras 43-8). Finally, the Court held that all matters relating to the manning of cruise liners exceeding a certain size were the responsibility of the flag state, irrespective of whether such cruise liners also provided island cabotage services (paras 53-6). Commission v. Spain (Vigo), 2006 also concerned sea cabotage. Under Spanish regional law a concession was required to operate transport in the Vigo estuary, with only one single concession on offer which was valid for 20 years and subject to experience with transport in the Vigo estuary. According to the Court, Regulation 3577/92 applied, although the Vigo estuary was situated inland, 'a river valley inundated by the sea' (para. 29), the impact on the internal market was limited, and only limited port infrastructure existed. Based on Regulation 3577/92 the free movement of services was applicable (paras 23-35). The single concession and the conditions subject to which it was granted amounted to a restriction of the freedom of services. It was unjustified, since a system of booking of available seats would equally allow the traffic to be adapted, while being less restrictive. Further grounds argued by Spain, namely in essence the protection of the environment and the lack of profitability of the service, remained unsubstantiated (paras 43-9). A public service obligation could not lawfully be imposed under Regulation 3577/92, either, as a well established road existed, too, and parts of the transport were only seasonal (paras 58-9). The application of the standstill 
clause referred to in article 7 Regulation was, finally, restricted to the cases mentioned in article 6 Regulation which did not cover the Vigo estuary (paras 62-6).

In Agip Petroli, 2006 the Court next decided that the exception from the applicability of host state legislation in a case of island cabotage when it was followed by an international voyage, in which case article 3(3) Regulation 3577/92 rendered flag state legislation applicable, applied regardless of whether the vessel concerned had cargo on board or not during that international voyage (paras 13-7). However, abuse of Community law by ship owners could lawfully be prevented. That required objective evidence though that the aim of the international voyage without cargo was to circumvent application of the host state's legislation and that the ship owner actually benefitted from the application of flag state law (paras 18-24). In Enosi, 2006 the Court confirmed that article 6(3) Regulation 3577/92 did not confer any rights on individuals in Greece before 1 January 2004 (paras 16-21; the rest of the judgment concerned Directive 98/18 on passenger ships).

In Commission v. Greece (towage), 2007 the Commission claimed that Greece violated Regulation $3577 / 92$ on maritime cabotage in that only ships under Greek flag could provide certain towage services in Greek waters. The Court rejected that claim finding that towage did not constitute maritime cabotage, for cabotage implied transport of persons or goods, while towage did not involve a straightforward carriage of goods or persons, but rather assistance for the vessel transporting goods or persons. Hence the Regulation did not govern towage (paras 29-33). (The Commission did not allege violation of the free movement of services.) In contrast, in Commission v. Greece (ports), 2007 the Court held that Regulation 4055/86 on maritime transports was violated in that Greece tolerated that certain entities levied several duties that were higher in cases of transports between Greek ports and ports in other states than in cases of transports between two domestic ports (paras 24-9).

\section{Broadcasting}

The Court dealt with television and broadcasting in a broad sense in numerous decisions. In Canal Satélite, 2002, Spain required operators of pay television services via satellite to obtain an administrative authorization subject to technical specifications and to be registered in Spain together with the products they marketed like decoders, etc. After having decided that Directive 95/47 on standards of TV signals did not preclude an authorization procedure (para. 27), the Court examined the case from both angles of the free movement of goods and services at the same time, since in pay TV and telecommunications in general services and goods were intricately linked (paras 31-3). The Court accepted Spain's registration requirement owing to the need to protect consumers, but reminded the national authorities of the Court's case-law relating to administrative authorizations, namely the exclusion of discretionary conduct by the authorities, the need to make the criteria public beforehand, and the requirement to take account of 'home' state regulation. The ruling, in addition, emphasized two points, namely 
that a prior authorization could only lawfully be required when ex post facto control was not at least as effective (paras 39-40); and that the authorization procedure was not to have a deterrent effect because of the duration, the cost, the ambiguity in conditions, and delays (paras 41-2). In RTL, 2003 the Court then interpreted the terms 'films made for television' and 'series' under Directive $89 / 552$ on television broadcasting in the light of consumer protection in order to define the amount of advertising that could be inserted in those broadcasts, concluding that the freedom of expression was not violated.

In Commission v. France (alcohol ads), 2004 certain French rules designed to minimize the presence of alcohol in television were at issue. Generally, advertising alcoholic beverages on television was prohibited in France, while ads in other forms, such as in the press, were permitted. French law required broadcasters established in France when broadcasting sporting events taking place abroad which were especially targeted at the French public, viz. bi-national events, to use all means, including technical, to make sure that advertisement of alcoholic beverages did not appear on screens, for instance on $t$-shirts of players or billboards. In particular, they had to use all means to prevent foreign organizers of such sporting events to show such advertisement. According to the Court, the freedom of services of a number of actors was restricted, namely of French broadcasters who had to refuse to retransmit certain sporting events; of the organizers of sporting events in other member states who could not sell certain retransmission rights; and of the owners of advertising hoardings who had to refuse certain advertising (para. 26). In particular, the use of technical means to prevent ads from appearing on the screen entailed additional cost (para. 28). The restrictions involved were justified, though, on grounds of public health. The French rules discouraged alcohol consumption by reducing the visibility on screen. It was not inconsistent with that aim that advertising beverages with an alcohol content of less than 1.2 per cent and advertising tobacco were not prohibited. Those exceptions were covered by the discretion a member state had in this regard. Moreover, the rules applied only to bi-national events and, generally, less restrictive measures were not available. That other member states administered a lower level of public health protection did not render the French rules disproportionate. Further, a duplication of the regulatory burden was not involved. The rules were, finally, sufficiently clear and precise (paras 30-9). Bacardi, 2004 was handed down on the same day as Commission v. France (alcohol ads), 2004 and was identical in content. The Court only added, first, that Directive $89 / 552$ on television broadcasting was not applicable, because indirect advertising, such as on hoardings, did not constitute advertising within the meaning of the Directive (para. 27), and, second, that the member states' discretion allowed them not to prohibit advertising in the background of film sets without being inconsistent (para. 40).

In Mediakabel, 2005 the Court qualified the 'filmtime' pay-per-view service provided by a Dutch company as a television broadcasting service within the scope of Directive 89/552. The customer could purchase the right to view a spe- 
cific movie at a certain pre-set time on Mediakabel's channel and a key the customer obtained after the purchase allowed the customer to decode the channel during the time the movie was screened. According to the Court, that service was a broadcasting service within the meaning of Directive 89/552, rather than an information society service governed by Directive 98/34 (paras 29-32 and 37-44). In particular, the Court rejected Mediakabel's argument that Directive 89/552 could not be applied since the obligation contained in the Directive to broadcast for the main part works of European origin could not be implemented with such an on-demand service. In the view of the Court, (i) the overall broadcasting time was clear and European programmes could be allocated broadcasting time in proportion to that time, irrespective of how often movies were in fact demanded, (ii) possible adverse consequences for a trader to whom a piece of legislation was intended to apply were not to determine the scope of that legislation, and (iii) a narrow interpretation of the term television broadcasting service possibly jeopardized the aim of Directive 89/552 (paras 48-51).

ORF, 2007 again concerned Directive 89/552 on television broadcasting. The Court qualified under the Directive a prize game offered on Austrian television in which the viewer was encouraged to call a toll number in order to be selected to participate on air in a game or alternatively to participate in a weekly prize drawing. Depending on the circumstances, the prize game could constitute 'teleshopping' or 'television advertising' within the meaning of the Directive. According to the Court, the offer to the viewers possibly constituted a service, since the cost of the call were higher than for a regular call. The service consisted in the participation in a game in the hope of winning, in keeping with the Schindler, 1994-line of authority (paras 32-4). To be qualified as 'teleshopping' the national court in addition had to assess whether a real service was offered notably in the light of the purpose of the broadcast, the importance of the game within the entire broadcast in terms of economic effects and benefits and timewise, as well as the questions the candidates were asked - in contrast to mere entertainment within the broadcast (paras 35-8). As to whether the game constituted 'television advertising' the national court had to examine all aspects of the broadcast and was not to confine itself to finding that the game was intended to make the broadcast more attractive. It was significant inter alia that the offer intended to make the viewer participate in the content of the broadcast itself, while it did not seek to extol the interest of the broadcast (paras 41-5).

United Pan-Europe, 2007 again concerned television broadcasting, although exclusively in the light of the free movement of services. Belgium's law knew a special must-carry status for television broadcasters in the region of Brussels. Cable network distributors were under an obligation to transmit the broadcasts of broadcasters with must-carry status, resulting in better economic conditions for the latter. However, the status was de facto obtained only by broadcasters established in Belgium. The Court judged that the status resulted in a restriction. It conferred an unconditional guarantee. It was more difficult for broadcasters without must-carry status to have their programmes broadcast. It was more like- 
ly that the status was granted to broadcasters established in Belgium. It was not necessary that all domestic broadcasters enjoyed an advantage (paras 32-7). Yet the restriction could be justified by a pluralist cultural policy and the freedom of expression given the wide discretion of the member states in that matter, if certain requirements were met. The award of the must-carry status had to be based on objective criteria and pursuant to a transparent procedure; the conditions and public service obligations the status involved had to be known in advance; the authorities' discretion had to be excluded; the number of broadcasters enjoying the status had to be limited and the programmes enjoying the must-carry status had to be restricted to those that were suitable to attain the aims of the cultural policy. In contrast, it could not be taken account of where a broadcaster was established, else the requirements were discriminatory; when the requirement could more easily be met by domestic broadcasters, they had to be essential (paras 46-50).

In Centro Europa 7, 2008 an undertaking was granted certain rights in Italy for broadcasting. However, due to a transitional arrangement implementing the switch from analogue to digital broadcasting that undertaking was not in fact allocated frequencies to broadcast. Instead, the incumbent networks merely continued to broadcast on those frequencies, thus blocking them, without having been subject to a selection procedure. The Court addressed the freedom of services, although the situation seemed purely internal to Italy, mainly to allow the national court to exclude reverse discrimination, while the Court refused to address a whole range of issues, notably under competition law, for lack of factual details (paras 64-70). According to the Court, the freedom of services and, from the time on it had become applicable, the new common regulatory framework for electronic communications services and networks consisting of a set of directives precluded the granting of rights to broadcast while the allocation of frequencies necessary to make use of those rights was refused (paras 85-9). Were equally unlawful the perpetuation of the positions of the incumbents, since they had not been selected in a procedure applying transparent, objective, non-discriminatory, and proportionate criteria. The transitional arrangement for the transit from analogue to digital broadcasting, assuming that it constituted a ground to justify a restriction of the freedom of services, did not provide justification, particularly because the incumbents' privilege to broadcast was not limited in time (paras 95-115).

In Dermoestética, 2008 a Spanish company offered cosmetic surgery services via a subsidiary in Italy. It concluded a contract with an Italian company to organise an advertisement campaign in Italy. However, the Italian company was unable to fulfil the contract, because Italian law prohibited broadcasting of ads for cosmetic surgery in private clinics on national television. On local television such ads were, however, permitted. The Court held that the prohibition of television ads was a serious obstacle to market access in Italy (paras 33-4). While the restriction could be justified on the ground of public health protection, because it was indistinctly applicable, Italian law was inconsistent in that it allowed ad 
campaigns on local television while prohibiting them on national television. The Italian prohibition was thus unsuitable to achieve the aim of protection of public health (paras 36-40).

In Kabel Deuschland, 2008 the Court had the occasion to clarify the mustcarry status under the Universal Service Directive (Directive 2002/22, a specific directive in the framework established by Directive 2002/21). The Court found the obligations imposed by the regulatory authority of a German Land on an analogue cable network distributor to be in compliance with Directive 2002/22. Subject to the national court's assessment of public interests and proportionality, such a distributor could basically be obliged to transmit channels which were already receivable through other terrestrial transmission means. Moreover, such a distributor could not lawfully oppose an order of priority of channels to be transmitted which the regional authority imposed, even if that order meant that all channels on the analogue cable network were fully utilised and the economic activity of the distributor was strongly restricted (paras 20-55). The Court, finally, decided that certain telemedia services, such as teleshopping, could constitute television services within the meaning of Directive 2002/22 (paras 58-68).

Uteca, 2009 was concerned with Spain's implementing legislation of Directive $89 / 552$ which required television companies established in Spain (i) to earmark five per cent of their operating revenue of the previous year for funding European cinematographic and television films. Of these five per cent (ii), 60 per cent had to be used for productions in one of Spain's national languages. Given that the Directive did not regulate the issue at all, Spain merely needed to comply with the market freedoms (paras 17-8). The Court did not find any restriction in the five per cent requirement (i) (paras 22-3). The other allocation requirement (ii), however, restricted the free movement of services as well as free movement of workers, establishment, and capital (para. 24). It was justified by the need to protect and defend national languages though, which need not have been laid down in more detail, given that the amount of funds concerned was relatively modest (paras 27-36).

\section{Public procurement}

In the 2000's, the Court developed public procurement case-law on the basis of the free movement of services in rather long series of cases. Commission $v$. France (public tender), 2000 was a case concerning the construction of certain public schools in a French department. The judgment mainly applied the public works directives, i. e. Directives 71/305 and 93/37. However, the Court also held that certain contract notices which were published in the Official Journal of the European Communities pursuant to the public works directives, violated the freedom of services. The notices made references to French standards and were, in essence, easier to comprehend for French undertakings. The resulting dissuasive effect amounted to indirect discrimination violating the freedom of services of providers established in other member states (paras 80-3). Furthermore, it 
could not lawfully be required in a notice that architects be registered with the order of architects in France (para. 87).

In University of Cambridge, 2000 the Court clarified the status of universities, such as the university of Cambridge, under the public contracts directives, viz. Directives 93/36, 93/37, and 92/50. The Court notably explained when a university was to be considered as being 'financed, for the most part' by the state or other public bodies, and hence could qualify as a 'body governed by public law' within the meaning of articles 1 (b) of the Directives. In that context, the Court remarked preliminarily, much like in Gemeente Arnhem, 1998, that the purpose of coordinating awarding procedures was to eliminate barriers to the free provision of services and goods (para. 16). The Court again relied on that passage in SIAC, 2001 in the context of the award of a public works contract under Directive 71/305 on public works contracts, which (the award) had been based on the opinion of an expert evaluating the most advantageous tender (para. 32).

In HI, 2002, the Court was faced with an issue in a public service contracts case. An Austrian authority had withdrawn an invitation to tender, after tenders had been submitted. A tenderer tried to challenge that decision in court, but Austrian law did not provide any possibility for legal review. When interpreting Directive $92 / 50$ on public service contracts the Court fell back on the free movement of services and establishment and the judgments in Unitron, 1999 and Telaustria, 2000, a public supply and a public service contract case, respectively, in which the Court had inferred an obligation of transparency from the principle of non-discrimination on grounds of nationality (paras 31 and 60-63, respectively), to find that Directive $89 / 665$ on review procedures for public contracts was applicable to the effect that a legal review in case of a decision to withdraw a call for tenders was indispensable (paras 43-8).

In Coname, 2005 the Court applied the freedom of services to a public service concession. In Italy, a municipality held 0.97 per cent of the shares of a company; the rest of the shares were predominantly held by other public, but also by private entities. The municipality concerned directly awarded that company a concession for the distribution of gas. Coname, the company that had previously provided those services, claimed that the municipality had failed to tender publicly the concession. The Court first assumed that the public contracts directives 92/50 and 93/38 were not applicable (paras 9-10 and 16). Instead, the freedom of services and establishment were to be applied. A lack of transparency when awarding such concessions amounted to a difference in treatment that worked to the detriment of service providers established in other member states that could be interested in such concession. Such providers then lacked the opportunity to express that interest. The concession needed not have been tendered publicly, but the appropriate information had to be made available. Further, it could not be argued that the effect on the freedom of services and establishment was too uncertain and indirect, despite the municipality's modest stake in the company licensed (paras 16-22). The need to control a concessionaire managing a public service - even assuming that that consideration could generally justify a lack of 
transparency - did not prevail in the case at issue, given the municipality's lack of control over the company and the fact that the company was open to private capital (paras 23-26). Parking Brixen, 2005 confirmed that the freedom of services and establishment and non-discrimination required transparency when the public contracts directives were not applicable. Equal treatment of tenderers for a public service concession was necessary even in the absence of discrimination on the basis of nationality. The concession to be awarded had to be advertised sufficiently so that competition was possible and the impartiality of the proceedings could be reviewed. Not to call for tenders at all was in any case unlawful (paras 48-50). Drawing on public contracts case-law the Court further elaborated that that obligation to act transparently was dispensable only when the company to which a public service concession was awarded met certain conditions, namely (i) it was controlled by the awarding public entity in a similar way as the public entity's own departments and (ii) the essential part of the activities of the company was carried out with the public entity concerned (paras 57-63). The Court then further clarified the condition of control (i). In particular, control was not given in the case at issue, because the company concerned had been newly incorporated as a company limited by shares and its objectives had been broadened, private individuals were basically allowed to acquire shares, the municipality did not have control over the management of the company, and the activity of the company was not limited geographically to the municipality (paras 65-71).

In Commission v. France (project delegation), 2005 the Court further clarified this strand of case-law. In cases in which the public service contracts directive 92/50 was not applicable, in particular because the threshold it set was not reached, France was required to admit companies established abroad on an equal level as French legal persons to serve as agents with specific tasks in relation to public service contracts under French law, else an obstacle to the freedom of services subsisted which, in addition, was not justifiable by the official authority derogation (paras 68-9). In Contse, 2005 the Court again tested a call for tenders against the free movement of services. In a call for tender to provide certain services related to home respiratory treatments and other breathing techniques, notably oxygen delivery, only companies that had an office in town which was open during certain hours were admitted. This criterion was also relevant for the evaluation of the answers to the call, as were certain production plants situated within 1000 kilometres from the province concerned and operated by the company answering the call. The evaluation also depended on the production capacity of those plants. In the event the evaluation resulted in a tie between two tenderers, the tenderer that had provided the service previously was awarded the contract. The Court decided that the admission condition raised the costs of answering the call for tenders and, as a result, made it less attractive. The evaluation criteria also hindered the free movement of services, in particular the requirement to operate certain plants within a given perimeter. The preference in case of a tie hampered the freedom of services, because the market was homoge- 
nous and all players essentially provided similar products (paras 29-32). Subject to the national court's assessment, the condition of having an office in town did not stand the Gebhard, 1995-test the Court applied, since it was not essential for the service or necessary to guarantee the health of patients (paras 35-45 and 55). Having a production plant within reach, even assuming that that criterion was not discriminatory, could not be an evaluation factor, either, as the health and life of patients could be guaranteed by storing a certain amount of the gas required locally. Delivery delays could also occur when producing within the perimeter (paras 56-68). The maximum production capacity of the plant had to be left out of account, too, for it was not tailored to the contract to be awarded (paras 69-76). Discrimination, finally, resulted from the bias in favour of the previous contractor in the event of a tie (paras 77-8). In ANAV, 2006 the Court reiterated that in case of a public service concession, i. e. when Directives 92/50 and 2004/18 on public services did not apply, the freedom of services did not require transparency to take effect when the municipality concerned had control over the undertaking receiving the concession. Conversely, if a third entity acquired stock in such an undertaking serving as a public service concessionaire, transparency applied with all the consequences established in the case-law based on free movement of services (paras 27-32).

In Commission v. Italy (horse races), 2007 Italy had decided to increase the number of licences available for horse-race betting operations from 329 to 1000. While Italy had invited tenders publicly for 671 licences, the existing 329 licences had simply been extended. Those licences were, according to the Court, public service concessions which were not covered by Directive 92/50 on public service contracts. In keeping with the case-law, an extension of existing licences violated transparency and thus constituted a restriction of the freedom of services and establishment (para. 25). Italy had failed to show that the extension of the licences was suitable to prevent the development of clandestine betting. Consequently, the freedom of services was violated (paras 30-4).

In Commission v. Ireland (An Post), 2007, the Irish state had contracted out the service of payment of social welfare benefits on behalf of the Irish state to the Irish postal company An Post, without having followed any competitive tender procedure first. That contract came within the scope of Directive 92/50, namely Annex $1 \mathrm{~B}$ which in cases of non-priority such as that at issue did not require a call for competitive tenders, but merely a certain degree of ex post publicity. Nonetheless, the Court reiterated, a member state had to comply with the freedom of services and establishment and the public service contracts case-law established based on them when the contract to be awarded had a cross-border dimension despite the listing in Annex 1B (para. 29) - a dimension which the Commission had failed to establish in the case at issue (paras 32-4).

In Asociación Profesional, 2007 a Spanish ministry had offhandedly concluded a contract with the Spanish universal postal service provider Correos. According to that contract Correos basically provided the postal services for the Spanish state. After having found that public procurement case-law did not apply to the 
services lawfully reserved to a universal postal service provider in accordance with Directive $97 / 67$ on postal services and having confirmed the violation of Directive 92/50, the Court went on to examine the freedom of services and establishment in case the contract concluded did not cross the pecuniary threshold established by Directive 92/50. The Court ruled that the case-law created on the basis of the freedom of services, in particular the duty to establish transparency, then applied. The in-house exception developed in that case-law was not pertinent in the case at issue, since the non-reserved services were equally provided to a wide range of customers, not just to the Spanish state (paras 86-7 and 58-63). The contract was only outside the scope of the case-law, if the contract was in fact a unilateral administrative measure that created only obligations for the universal postal service provider and departed from regular commercial terms, leaving no possibilities to negotiate or cancel it (paras 85 and 54-5).

In Commission v. Italy (public works), 2008 the Court, apart from examining the public contracts directives, reiterated that the case-law on the freedom of services and establishment applied below the thresholds of those directives in cases of cross-border interest. Given that application, Italy was not required to adopt particular rules in that regard when implementing the directives (paras 67-8 and 81-2). The Court, finally, in the context of the Commission's general claim that Italy had violated equal treatment, mentioned that the freedom of services and establishment did not contain a general obligation of equal treatment, but rather a prohibition of discrimination on the basis of nationality (para. 106).

The general approach in public procurement was confirmed and refined in Secap, 2008 in which Italian law had required public authorities that called for tenders to exclude automatically those offers submitted that were abnormally low, except when only five offers or less had been submitted. Abnormality was determined by means of a mathematical formula. The authorities notably did not have the possibility to examine those abnormally low tenders. According to the Court, where the public works Directive 93/37 did not apply due to the threshold not being exceeded and where a cross-border interest was at stake, which could be the case due the location of the work to be performed, even with contracts of very low value (para. 31), the automatic exclusion of low tenders was liable to undermine the principles established by the case-law on the freedom of services and establishment. Foreign competitors sometimes had different price structures and economies of scale and at times undercut the market with their offers in order to enter a market. With the automatism they were deprived of the possibility to prove why their tenders were low. Moreover, the automatic exclusion could give rise to collusion by local companies. Thus, access of foreign competitors to the Italian market and effective competition were impeded. Automatic exclusion could only be an option where a very large number of tenders had been submitted, while five tenders did not amount to a very large number (paras 24-33).

In Brescia, 2008 the Court sanctioned the way an Italian municipality ended a long-term gas distribution concession, which would have been valid until the 
year 2029, with the aim of freeing space for a common gas market by a transitional regime. The end of the concession provided by that regime, however, was removed for two years. According to the Court, the award of a new concession would have been subject to the requirements flowing from the freedom of services and establishment, viz. transparency, etc., given the cross-border interest. Thus, the extension of the old concession under the transitional regime raised a restriction to the freedoms (paras 57-63). That restriction could be justified by the need to guarantee legal certainty, in essence since in 1984 when the concession had been awarded the Court had not yet ruled on the applicability of the market freedoms to such a concession. It was up to the national court, however, to decide whether the extension of the concession was necessary to ensure legal certainty (paras 64-72).

Thereafter, Coditel, 2008 clarified the in-house exception to the requirement of transparency under the freedom of services and establishment, i. e. when the public contracts directives were not applicable. The Court decided, after having examined in detail the legal nature of the inter-municipal cooperative concerned in the case at issue, that the award of a concession for the management of a municipality's cable television network to that cooperative came within the in-house exception, essentially because it was wholly owned and fully controlled by municipalities the interests of which it was bound to pursue (paras 28-40). Joint control by public authorities was sufficient for that purpose, provided that the body concerned worked mainly with the authorities concerned (paras 44-53). In Sea, 2009 the Court refined the in-house exception. The Court confirmed that it fell to be applied in the same way under the freedom of services and establishment as under the public contracts Directive 2004/18 (para. 37). Moreover, in essence prospective ownership in a public company by private owners, which would exclude the in-house exception, had to be a real possibility in short term to be taken into account (para. 50). If that possibility turned into reality, though, a competitive tender for a running contract was required (para. 53). The Court also added that the level of control exercised by public authorities over a company had to be assessed in the light of the applicable legislation, the market-orientation of the company, and the control mechanisms (para. 66). The Court then applied those criteria to the company at issue (paras 67-89).

In Eurawasser, 2009 the Court confirmed that public service concessions did not come within the scope of Directive 2004/17, but were subject to the case-law established under the freedom of services and establishment (para. 44). The Court then went on to elaborate the distinction between a public service contract and a public service concession, notably with regard to the consideration for the service and the risk to be born by the service provider (paras 49-79).

In Acoset, 2009 an Italian municipality intended to set up a public-private company and entrust it with the management of water services. The Court, after having found that a public service concession was at issue (paras 40-2), ruled in the light of the freedom of services and establishment that it was not necessary to organize two public calls for tenders, one for the selection of the private minority 
shareholder with the capacities to perform the services needed and a second to entrust the entity founded for the sole purpose of providing a service with the concession. One public invitation for tenders to find a proper private partner was sufficient, provided, however, that the corporate purpose of the entity founded remained the same for the duration of the concession (paras 58-62).

In Serrantoni, 2009 the Court invalidated an Italian rule which automatically excluded a consortium and a member of that consortium from a tendering procedure, whenever that member submitted a tender in the same procedure at the same time as the consortium itself. The rule also threatened criminal sanctions in such a case. While recognizing a certain amount of discretion of the member states to adopt rules to ensure compliance (para. 31-2), the Court found that, in a case in which the threshold established by Directive 2004/18 was not crossed, the automatism in the rule amounted to a restriction of the freedom of services and establishment, quite apart from the fact that the measure at issue discriminated against some consortia. It was not possible for a tenderer to rebut the presumption. Moreover, the restrictive effect on tenderers established abroad was not justified by the need to forestall collusion between tenderers (paras 38-45).

\section{Ankara}

Some cases in the 2000s dealt with free movement of services in the context of the Ankara Agreement with Turkey. In Abatay, 2003 Germany required Turkish drivers who transported goods in lorries registered in Germany from Turkey to Germany on behalf of Turkish subsidiaries of German companies to have work permits. The Court decided that those workers could not lawfully rely on articles 6 and 13 Decision 1/80, because they did not seek access to the employment market in Germany. They were employed by the Turkish subsidiary, stayed in Germany only for brief terms, and returned to Turkey immediately thereafter (paras 89-91). According to the Court, essentially for lack of a title on transport in the Ankara Agreement, the internal market case-law according to which the freedom of services did not apply in transport until implementing secondary legislation was adopted was not applicable. Instead, the freedom of services applied directly in the transport sector under the Ankara Agreement. Moreover, the standstill clause addressing services as well in article 41 Additional Protocol to the Ankara Agreement which essentially froze the level of service restrictions as per its entry into force was to be applied directly and, in addition, to be interpreted for services, workers, and establishment in the same way (paras 67, 92-103). The Turkish nationals whom the Turkish company employed and who were indispensable for the provision of its services were entitled to rely on the freedom of services and on the standstill clause, since the service was destined for a recipient in a member state, whereas the German company could not lawfully rely on the freedom of services against Germany, because it received the service in Germany (paras 106-8). Given that the internal market case-law on the free movement of services needed to be extended as far as possible to the Ankara Agreement, the requirement for the Turkish drivers to have a work permit in 
Germany constituted a restriction of the freedom of services. Further, it was an unsuitable restriction, because the workers were not intent on access to the German labour market. Whether the restriction had already existed in national law at the time the Additional Protocol had entered into force and it was thus within the scope of the standstill clause was up to the national court to decide (paras 111-6).

Soysal, 2009 also concerned the free movement of services under the Ankara Agreement. Turkish lorry drivers who were employed by a Turkish company lawfully transported goods in Germany in lorries owned by a German company and registered in Germany. Initially, at the entry into force of the additional protocol to the Ankara Agreement which contained the standstill clause in article 41(1), a visa was not required for the kind of services these drivers provided in Germany. Later on, a visa was required, but it was consistently granted up to a certain point when the German authorities learnt that the lorries they drove were registered in Germany. Then the visa were no longer granted. Together with the legislation of the Union in the area of Schengen the German legislation had changed again. Pursuant to that legislation, a visa was required which was valid for the entire Schengen area. In keeping with its case-law on the standstill clause in the Additional Protocol, the Court reiterated that more restrictive measures could not be enacted than those applicable at the time the standstill clause had entered into force. Since a visa had not been required at that time for the provision of such services in Germany, a visa requirement was not to be imposed now (paras 51-3 and 57-8). It was not relevant whether the requirement was based on a measure of the Union or a member state's measure implementing legislation of the Union; or whether the Schengen visa had some advantages as compared to the regime originally in force. The visa requirement introduced an additional burden and if a visa was denied, provision of services became impossible (paras 54-5). Apart from that, an international agreement such as the Ankara Agreement took precedence over the secondary legislation of the Union which, therefore, had to be interpreted in accordance with the agreement (para. 59).

\section{Further services cases}

A whole series of other cases concerned the free movement of services, but resists a similar categorization as above. In rough chronological order they were the following. Commission v. Italy (cleansing services), 2000 invalidated Italy's registration requirement which applied to all undertakings offering certain cleansing services such as rodent-control. Italy had failed to take due account of 'home' state registration and, as a consequence, violated the free movement of services (paras 13-4).

With Deliège, 2000, certain aspects of Bosman, 1995 were applied in the freedom of services. Ms Deliège was a judoka performing on the highest level in Belgium. She was repeatedly ignored in the Belgian federation's selection of judokas for international tournaments, the results in which inter alia determined how many athletes could be fielded for the Olympic games. She alleged violation of 
her freedom to provide services. The Court first reiterated, mostly in keeping with the Bosman, 1995-case-law, that the Treaty applied to professional sports such as judo. Then the Court ruled that the selection made in the case at issue was not for national teams the activities of which had been considered as noneconomic in Bosman, 1995 (paras 43-8). For the question whether judokas offered services it was relevant that they were usually supported by public grants and private sponsors (paras 51-2). Moreover, the activities of high-level athletes involved a number of separate but closely related services within the sense of the freedom of services, although not all of them were paid for by those who received them. They allowed other service providers, such as event organizers or broadcasters, to offer services (paras 56-7). As for the question whether the case was purely internal to Belgium, the national court had to bear in mind that a certain degree of extraneity was involved when an athlete performed abroad (paras 58-9). Unlike in Bosman, 1995, however, the Court did not find a restriction of a Treaty freedom. The federations did not select candidates based on nationality, nor was access to the labour market denied. It was in the nature of such sport events that a selection had to be made. Participation in the events had to be limited in some way. A whole number of considerations unrelated to the individual athlete were factored into the decision on whom to select. It was therefore appropriate that national federations laid down a selection procedure and selected athletes (paras 61-9).

In Corsten, 2000 Germany required persons established abroad to be registered on the German skilled trades register to be allowed to provide the corresponding services in Germany. In the case at issue, Mr Corsten, a German architect, had had a Dutch company lay floors in Germany, an activity which that company lawfully pursued in the Netherlands. In keeping with case-law on the freedom of services, compliance with which was required despite Directive $64 / 427$ on industry and small craft industries, the Court struck down the registration requirement (paras 30-4). Acknowledging that the need to guarantee the quality of skilled trade work could justify a restriction (para. 38), the Court held that Germany had failed to draw a distinction between those established in Germany and those merely providing services, imposing the same requirement on both (para. 44). The examination which Directive 64/427 permitted could be one of form only (paras 41-2). The Court further clarified that any authorization procedure was not to delay or impede the provision of services when the conditions to exercise the activities in question had been met. Moreover, no additional expense was to arise, nor could payment of subscriptions to chambers of trade be lawfully imposed (paras 47-8). In Commission v. Italy (register), 2000 the Court struck down Italy's requirement for persons providing services in haulage to have an Italian authorization and to be registered in Italy. The requirement was incompatible with the free movement of services and establishment. (Italy had not contested the Commission's allegation).

The primary interest of Gourmet, 2001 was in the free movement of goods under the Keck and Mithouard, 1993-line of authority. However, it also had a 
service dimension. Sweden prohibited all advertising of alcoholic beverages bar comments in the editorials of magazines and advertising directed at traders. That prohibition restricted cross-border services of the domestic press in advertising (paras 38-9). Like the restriction of free movement of goods, it was justifiable by public health concerns, except if the national court found the measure to have been diverted from its original towards protective purposes (paras 40-1 and 26-33).

In Commission v. Italy (transport consultants), 2001 the Court reviewed a number of requirements Italy imposed on transport consultants, namely an authorization was needed which was only granted after a security deposit had been lodged; minimum and maximum fees applied; nationals of other member states had to have residence in Italy. The latter requirement negated the freedom of services and, as regarded the freedom of establishment, was discriminatory (paras 14 and 21). The authorization coupled with the deposit constituted a restriction of the freedom of services which was not justified, because Italy failed to take into account similar 'home' state regulation with which a service provider established abroad had complied already (paras 22-4). In contrast, the Commission had failed to show how the minimum and maximum fees violated the free movement of services (paras 25-6).

In Commission v. Italy (trade-fairs), 2002 the Court struck down a series of restrictions by local and regional entities in Italy relating to the organisation of trade-fairs. Since Italy did not dispute the infringement (para. 19), the Court in brief terms invalidated the requirements for trade-fair organizers (i) to obtain official recognition from the relevant authorities, (ii) to have a permanent establishment in Italy and a particular legal form or status, (iii) to organize exclusively trade-fairs, (iv) to operate on a not-for-profit basis, (v) to hold fairs periodically, (vi) to conform to the aims set by the region concerned, (vii) to abide by particularly strict time-limits in the procedure to obtain the necessary administrative authorization, and (viii) to have fairs included in the official calendar (paras 28-33). Yet certain subsidies were considered not to be restrictive (para. 32). Moreover, a number of requirements were contrary to the freedom of services and establishment, namely (i) the involvement of public authorities in administrative appointments, (ii) the inclusion of at least one local territorial institution among the founders or the members of the body concerned, and (iii) the involvement of bodies made up of operators already established in the region concerned in certain decisions (paras 36-40. Only the involvement of certain persons who did not compete with the trade-fair organizers was considered justified (para. 41).

In Commission v. Italy (temporary labour), 2002 the Court invalidated a number of requirements Italy imposed on those who provided temporary labour to businesses in Italy. The requirement to have an establishment in Italy was not indispensable within the sense of Parodi, 1997 for the protection of workers, as some workers possibly were not in need of protection in Italy, particularly when they resided abroad or usually worked in Italy under an employment contract, 
and the Brussels framework allowed workers to sue employers in a court at the place where they worked (paras 20-5). It could not be demanded from a foreign provider of temporary labour services to provide the same bank guarantee as Italian providers, as that requirement failed to take into account comparable guarantees provided in the 'home' state (paras 32-4). Moreover, if that guarantee was to be provided through a bank established in Italy, the freedom of banks established in other member states to provide services was unlawfully restricted, too, as was the freedom of capital of the service provider (paras 36-9).

In Carpenter, $2002 \mathrm{Mr}$ Carpenter, a British national, was resident in the United Kingdom. He had several clients in other member states to whom he sold advertising space in certain British journals. For that purpose he also travelled to other member states. His wife was a national of a third country, who had initially entered the United Kingdom with a visitor visa. She stayed beyond the validity of her visa and later on married Mr Carpenter, thenceforth taking care of his children stemming from his first marriage. This in turn allowed Mr Carpenter to devote more time to his business activities. As her stay in the United Kingdom was illegal, she was going to be deported. The Court decided that Mr Carpenter's freedom to provide services was affected since he provided a significant part of his services to receivers in other member states (paras 29-30). In contrast, Directive 73/149 did not apply vis-à-vis the state of which a person was a national (paras 34-6). Mr Carpenter's freedom of services would have been violated by his wife's deportation. The separation would have been detrimental to the Carpenters' family life and deterred him from providing services (paras 38-9). Any assessment of the justification of that interference would have to be compatible with the Carpenter's right to family life, protected by article 8 European Convention of Human Rights. To deport her would not strike a fair balance between the right to family life and public order and safety, in particular since she had not committed any offence other than staying in the United Kingdom beyond the validity of her visa. Moreover, the Carpenters' marriage was genuine (paras 40-5).

The Commission in Commission v. Italy (local museums), 2003, again after Commission v. Spain (museum admission), 1994, challenged admission fees for cultural sites. Some local and decentralised authorities in Italy had granted Italian citizens and local residents of a certain age free admission to the local museums and monuments they ran. In keeping with Commission v. Spain (museum admission), 1994 the Court found the freedom of services to be violated. Relying on Italian citizenship was discriminatory. Residence as a criterion for distinction resulted in indirect discrimination, though not all of those disadvantaged were nationals of other member states (paras 12-5). Justification of the direct discrimination failed, for none of the grounds expressly mentioned in the Treaty applied. The residence requirement was not justified by the cohesion of the Italian tax system, not merely because the direct link required was missing, but also because not just local residents, but all residents of Italy paid tax. Finally, Italy could not 
validly plead its federal structure to justify the discriminations, either (paras 19-27).

In Commission v. Italy (patent services), 2003 again a residence condition was at stake. Italy required those who provided certain services related to patents and the patent office in Italy to have residence or a place of business and to be registered in Italy. The Court assessed the situation from the angle of the freedom of services rather than the freedom of establishment, because the services concerned did not necessarily involve stable and continuous participation in the economic life in the host state (paras 23-5). The registration requirement was an obstacle. The corresponding aptitude test which all applicants had to take failed to take into account qualifications already acquired by those established abroad in their 'home' state. Hence, the registration requirement was not necessary to ensure the quality of the services provided or the protection of the service recipient (paras 27-32). Equally, the residence condition was an obstacle which was not justifiable for it went beyond what was needed to determine the court having jurisdiction in patent lawsuits or for the proper administration of justice (paras 42-5). In any event, Italy could not lawfully require reciprocity from other member states (para. 46). In a similar vein, the Court in Commission v. Luxembourg (patent agents), 2003 overruled Luxembourg's requirement for foreign patent agents to elect domicile with an approved agent in Luxembourg in order to provide services (para. 19). (Luxembourg had not disputed the infringement.)

In Freskot, 2003 the Court assessed an insurance scheme Greece had established. The Greek state levied a charge on the sale and purchase of domestic agricultural products. That charge served to feed a public entity which in turn covered natural risks farmers in Greece typically faced. Besides the free movement of goods, agricultural policy, and state aid, the Court also examined the freedom of services. According to the Court, a service was not provided by means of that insurance scheme. The charge levied was not consideration for a service, because it was levied by tax authorities, it applied equally to all operators, and its characteristics were determined by the legislature (paras 56-8). Hence, the freedom of services and, as a consequence, Directive $73 / 239$ on direct insurance were not applicable in that respect. The freedom of foreign insurers to insure in Greece the kind of risk the Greek scheme covered was possibly restricted, though. However, it was unclear whether the risks covered were insurable profitably by private insurers. Yet even if they were, the restriction was susceptible of justification. The scheme pursued the social policy goal of ensuring an adequate level of protection for all farmers, regardless of the individual risk each of them faced, and the rate of the charge was the same across the board, again irrespective of the individual risk. It was up to the national court, though, to assess the proportionality of the cover. It had to factor in that the Greek scheme provided only minimal cover and farmers were free to conclude contracts to increase insurance protection (paras 63-73). 
In $A M O K, 2003$ an Austrian company won a court case in a German court. Consequently, it required the losing party to pay the fees of the Austrian lawyer who had conducted the lawsuit on its behalf in accordance with the scale of fees applicable in Austria. In addition, it requested reimbursement of the fees the work in conjunction with a German domestic lawyer had occasioned. According to German law it was mandatory to work in conjunction with a local lawyer for foreign lawyers. Both requests were rejected by the German court of appeal, which instead applied the German scale of fees which was less advantageous for the Austrian company and declared the fees of the local lawyer as not recoverable. Both rejections, according to the Court, constituted restrictions of the freedom of services, for they rendered services supplied by providers established in other member states less attractive (paras 27 and 36). The German scale of fees could lawfully be applied, though, because host state rules and conditions could in principle be applied to trans-frontier services, a point also emphasized by $\mathrm{Di}$ rective 77/249 on lawyers. Moreover, application of the German scale was predictable and thus complied with legal certainty (paras 29-30). In contrast, to reject reimbursement of the additional fees resulting from the work of the local lawyer violated the freedom of services, because German law, making use of an authorization in Directive 77/429, required foreign lawyers to work in conjunction with a domestic lawyer. The fees such domestic lawyers charged were, in addition, modest, since their role was limited (paras 38-40).

Schnitzer, 2003 followed up on Corsten, 2000. A German company charged a Portuguese company with plastering work in Bavaria which took around three years to complete. The head of the German company was fined, because the Portuguese company was not entered into the German trade register as required by law. The Court reiterated that the distinction between the freedom of services and freedom of establishment had to be made on the specifics of each case. No abstract rule determined the point in time when services became establishment. Even regular services provided over several years did not necessarily amount to establishment within the meaning of the Treaty. If the national court found that the Portuguese company merely provided a service, given that it did not have any infrastructure in Germany and did not seek to evade German legislation (paras 30-3), the registration requirement constituted an obstacle as held in Corsten, 2000. That obstacle was susceptible of justification by the needs to protect those who commissioned the work and to ensure the quality of services. However, when 'home' state legislation demonstrably guaranteed the quality of services, the registration was not to complicate or delay the work, give rise to fees or contributions to trade chambers, or be a condition precedent to the provision of the service, irrespective of whether the service was provided repeatedly or just once (paras 37-9).

In Commission v. France (bio-medical labs), 2004 France required firms running bio-medical laboratories to have an establishment in France to be allowed to provide bio-medical analysis services. Such an establishment also rendered the cost of the service provision reimbursable under the French social security sys- 
tem. The requirement, according to the Court, restricted the freedom of services, though not the freedom of establishment, because a French branch could operate a laboratory and foreign nationals could act as directors (paras 59-62 and 65). It was an excessive requirement, however, even to guarantee the quality of medical services in order to ensure a high level of health protection. Inspections and controls which ensured that French standards were met obviously were in order, but an authorization requirement would have served those purposes just as well. Any such requirement would have to avoid duplicating the standards already met in the 'home' state. Proof of the fact that those 'home' state standards were not less strict and were actually complied with could lawfully be required from the foreign service provider who also had to ensure that French doctors and biologists understood the laboratory reports it supplied (paras 69-76). Similarly, a foreign service provider could lawfully be required to obtain an authorization in France which then rendered the cost of the services provided reimbursable under the French social security system. Such a requirement would be less restrictive than the condition to have a branch or a subsidiary in France (paras 91-4).

In Omega, 2004, a British company concluded a franchise contract with a Germany company to provide a fully functioning game hall where customers could 'play at killing' with laser guns. The German authorities prohibited that activity on the ground that it violated public order. According to the Court, the freedom of services was applicable exclusively, since the goods imported were entirely secondary to the services provided (paras 25-7). The prohibition was a restriction that was justified by public policy considerations, which could in principle justify indistinctly and distinctly applicable measures (para. 29). That the game was tolerated in other member states did not render Germany's prohibition disproportionate. On the contrary, the member states had a margin of discretion to define what public policy meant. A conception of public policy common to all member states was not necessary, either, contrary to what might have been inferred from Schindler, 1994 (paras 31 and 37-8). The objective of protecting human dignity, on the basis of which the German authorities had prohibited the game, was compatible with Community law. It was to be taken into account as a ground justifying restrictions of the market freedoms, as in fact any fundamental right (paras 34-5). The prohibition, finally, was not unnecessary, as it was limited to 'playing at killing' and the German constitution sought to guarantee a level of public policy protection that corresponded to the prohibition (para. 39).

In Burmanjer, 2005 the Court found the free movement of goods applicable, in contrast to Omega, 2004. Vendors had sold to pedestrians in the public sphere of a town in Belgium subscriptions to periodicals on behalf of a German company without having obtained the authorization Belgian law required for such itinerant activities. The Court ruled that the activity of the vendors consisted in the marketing of certain goods. The services associated with that marketing were entirely secondary. Hence, solely the free movement of goods and with it the Keck and Mithouard, 1993-case-law was to be examined, instead of services 
(paras 33-6). Free movement of workers did not apply, because the vendors were not employed by the German company (paras 18-20.)

In Oulane, 2005 a French national was deported from the Netherlands, because he had failed to prove his identity. He claimed to be in the Netherlands for the purpose of receiving services. The Court clarified a number of points. First, pursuant to Directive 73/148 on movement and residence based on establishment and services and the freedom of services nationals of other member states could be required by the host state to establish their identity when asked to do so. Yet proof of identity could be provided not only by means of an identity card, but by other means suitable to establish identity unequivocally (paras 16-25). Second, the host state could insist on nationals of other member states carrying a valid identity card or a passport only if its own nationals were required to do so, too, else discrimination arose (paras 32-4). Third, deportation and detention, as sanctions in case a national of another member state who received services in the host state had failed to present a valid identity card, were out of proportion to the need to ensure public security. The sanctions had to correspond to the penalties imposed for similar offences committed by nationals of the host state. The award of damages after a sanction had turned out to be unjustifiable did not render deportation or detention proportionate (paras 41-3). Fourth, it was up to the person concerned to prove her or his right of residence as a service receiver in accordance with Directive $73 / 148$ by any means appropriate, failing which she or he could lawfully be deported subject to the limits imposed by Community law (paras 49-5).

In Servizi ausiliari, 2006 Italy reserved the provision of certain services related to the declaration of taxes - advice, assistance, etc. - to particular companies constituted under Italian law. Although the situation seemed to be confined in all aspects to Italy, the Court gave an answer, because the national court possibly needed an answer to preclude reverse discrimination (para. 29). The freedom of services and establishment were restricted. The requirements were discriminatory in as far as the services were reserved to companies already established in Italy. They restricted access to the market, as far as the services were reserved to companies meeting certain requirements (paras 33-7). The grounds expressly mentioned in the Treaty did not provide justification in the case of discrimination (para. 36). Apart from that, the restrictions were not justified either (i) by the protection of service recipients, for the services were either simple and hence could not be reserved to persons having certain qualifications or, when more complex, the requirements to be met were not suitable to protect recipients, or (ii) the official authority derogation, for lack of a connection, since the services were provided only in the preparatory stage before the official authorities became involved (paras 36-48).

In Commission v. France (performing artists), 2006 France treated artists who came to France to perform as service providers as if they were in employment and consequently applied French social legislation, unless that presumption was rebutted. An additional requirement was undisputed; France admitted that the 
requirement to have a licence to pursue the activity of engaging performing artists which was issued subject to need on the French market violated the freedom of services (para. 29). As to the first requirement, according to the Court, France's approach amounted to a restriction of the free movement of services, irrespective of whether the presumption was hard or easy to rebut (paras 38-42). For lack of harmonisation, the restriction was susceptible of justification. Though as such a legitimate ground, the social protection of service recipients failed to justify the obstacle, as Regulation 1408/71 already provided social security protection for them. Further, the idea of guaranteeing paid leave could not be reconciled with self-employment. The need to combat concealed employment, finally, did not justify such a general approach. Instead, ex post facto controls and deterrent penalties on a case-by-case basis sufficed (paras 43-52).

In Meca-Medina, 2006, an annulment appeal in which professional swimmers attacked the rules against doping enacted by the international olympic committee, the Court held in accordance with its case-law that the freedom of services and other internal market law such as competition law - applied to swimming as a professional or semi-professional sport governed by said committee, and more specifically to the rules against doping (paras 22-33). Yet the initial complaint had been solely based on competition law, which essentially was not violated, since the rules at issue were justified by the need to keep the sport fair, provided that the sanctions ordered in case the rules had been violated were proportionate. In the light of this initial complaint the Court refused to enter into the merits of the claim alleging a violation of the freedom of services (paras 58-9).

Fidium Finanz, 2006 delineated the freedom of services from the free movement of capital. Fidium was a company established in Switzerland which offered short-term consumer credits in Germany via internet and credit intermediaries. Fidium operated lawfully in Switzerland, but was not established nor had a licence in Germany as required by German law in case of companies established in third countries. At the time the facts took place, the Association Agreement with Switzerland liberalising free movement of persons and services partially had not yet been in force. According to the Court, it was possible that both the freedom of service and the freedom of capital were applicable at the same time. With no order of priority existing between the two freedoms the Court would only examine one freedom, if the other was entirely secondary and could be considered together with the first (paras 25-34). In the case at issue, providing consumer credits constituted a service. However, a company established in a third country was not entitled to rely on the free movement of services, in contrast to the free movement of capital. The restriction in the flow of capital was merely the inevitable consequence of the limitation of the freedom of services inherent in Germany's licence and establishment requirements. The freedom of capital therefore need not have been considered (paras 38-49).

Cipolla, 2006 concerned Italian legislation which fixed on a scale the minimum and maximum fees lawyers were allowed to charge in Italy for in- and outof-court counsel. Derogations from those fees were not possible. Replying al- 
though the situation was purely internal to Italy so to enable the national court to deal with any potential reverse discrimination (para. 30), the Court decided that the Italian measure restricted the freedom of lawyers established in other member states to provide services in Italy. Like in Caixa-Bank, 2004, those service providers were prevented from competing effectively on the basis of prices and the choices for service recipients were limited (paras 58-60). Whether the protection of the service recipient and the proper administration of justice justified that restriction was left for the national court to decide. In taking the decision, the national court had to take into account the typical asymmetry of information between attorneys and clients, the possible lack of a link between the quality of the service and the price, the high number of lawyers operating on the Italian market, and other means to prevent destructive competition, such as professional rules, liability, and supervision (paras 64-7).

In Commission v. Austria (boilers), 2006 Austria required service inspectors of boilers and pressure tanks to be established in Austria. The restriction, the existence of which Austria did not dispute (para. 22), was not justified by public security and health considerations. An undertaking did not constitute a threat to public security by the sole reason of being established in another member state, in particular when a directive, like Directive 1999/36, had established minimum requirements for boiler inspectors to be met. With regard to the protection of public health less restrictive alternatives were available. An entire sector of services could, moreover, not lawfully be removed from competition on the ground that undertakings established in other member would otherwise have gained an unfair competitive advantage, else the freedom of services became dependent on harmonisation of all national rules. The protection of the domestic industry alone was not a ground justifying a restriction of the freedom of services (paras 25-31).

In Commission v. Italy (debt enforcement), 2007 the Court scrutinized a series of requirements Italian law imposed on those who offered the service of extra-judicial debt enforcement on a commercial basis. According to the Court, while a licence requirement necessarily restricted the freedom of services, a general declaration of good conduct for which to make a form could be downloaded from the internet, to be filled out and submitted to the authorities, did not amount to a licence in the sense of an authorization. Availability on the internet guaranteed sufficient publicity. Such a declaration was less onerous than an authorization. It could not validly be argued that it failed to take into account 'home' state regulation (paras 24-30). The Court also sanctioned the discretion of the Italian authorities to impose additional requirements on a case-by-case basis for police licence holders. The Commission had failed to show a single example in which such a requirement was imposed in a manner contrary to the freedom of services or establishment. There was no legal uncertainty (paras 35-9). In contrast, the requirement to have business premises in Italy and to display there the services offered was the very negation of the freedom of services and violated the freedom of establishment. Less intrusive means would have been available to 
guarantee the supervision of debt enforcement activities (paras 43-6 and 65-6). A territorial limitation of the 'licence' within the sense described above and, alternatively, the option to authorize an agent in regions other than where the 'licence' had been issued violated the freedom of services and establishment, for both requirements were unnecessary. Although indistinctly applicable, they provided domestic operators with better opportunities, since those operators were in a better position to establish contacts with agents in other regions. A declaration given in a single province would have sufficed for the purposes of supervision in all of Italy (paras 57-63). Although prices fixed by a member state could, according to case-law, amount to an obstacle to service provision given that an important variable for competition was eliminated, a non-binding recommendation of the prices to be charged for services, which in fact solely meant that an undertaking had to set objective and uniform price standards, was in accordance with the freedom of services and establishment, particularly when it was not proven beyond doubt that such a recommendation existed at all (paras 70-7). The simple clarification in a circular that the 'licence' to pursue extra-judicial debt enforcement activities did not imply a licence to offer banking and credit services, for which a separate licence was required, did not fall foul of the freedom of services (paras 83-5).

In Commission v. Austria (bio inspections), 2007 the Court dealt with controls of production in accordance with Directive 2092/91 on organic agricultural products. Austria required private bodies that conducted those controls to be established in Austria even when those bodies had already been approved abroad. According to the Court, the Directive had not harmonised the monitoring of organic agricultural production by bodies established in the member states. Accordingly, the member states had to comply with the market freedoms, in particular the freedom of services, in that regard (paras 28-30). The requirement to have an establishment in Austria, as a restriction of free movement of services, was not justifiable. The official authority derogation failed to provide justification for lack of a direct and specific connection. In spite of the tasks performed by the monitoring bodies - implementation, reporting, supervision, granting and withdrawal of the right to market products, etc. - it were the Austrian authorities that supervised those bodies and were ultimately responsible. The issue of certificates of conformity and certain powers to impose penalties could be separated from the other supervisory tasks. Hence, they did not justify a removal of the entire supervisory tasks under the Directive from the freedom of services (paras 31-49). The protection of consumers, in turn, was sufficiently guaranteed by the Directive's harmonisation of the approval of private supervisory bodies. It was less restrictive to require bodies established in other member states to submit proof of their approval. Moreover, a system of exchange of information was in place (paras 54-60).

Van Leuken, 2008 concerned a real estate agent lawfully established in the Netherlands. He specialized in services with regard to real estate situated in Belgium. The Belgian authorities ordered him to cease his activities on the ground 
that he did not have a Belgian authorization. He then cooperated with a real estate agent properly authorized in Belgium who was responsible for the legal aspects of the activities in Belgium. Belgium's authorities again opposed that practice. At one point he applied for authorization in Belgium, but he was told to take an aptitude test comprising nine legal subjects as a compensatory measure. The Court applied Directive 89/49, since the profession was regulated in Belgium, and the freedom of services. The person concerned, according to the Court, had to have the possibility to choose between a period of adaptation and an aptitude test, since knowledge of Belgian law was not required to exercise the profession (paras 37-8). The compensatory measure was, moreover, disproportionate to the need to protect consumers given that he did no longer exercise the profession fully, but cooperated with a local real estate agent (paras 40-1). Accordingly, a penalty could not be imposed for his failure to comply with national law (para. 42).

In Kattner, 2009 a German company challenged the compulsory affiliation to an association which provided statutory minimum insurance against the risk of accidents at work. Kattner wanted to take out accident insurance with a company established in Denmark. Having ruled that competition law was inapplicable, the Court found that the compulsory affiliation amounted to a restriction of the freedom of services, which applied despite the power of the member state to organise their social security systems (paras 72-6). Although it was uncertain whether accident insurance could be run profitably by private insurers, the compulsory affiliation prevented service receivers from taking out some insurance with insurers established abroad (paras 80-3). Yet the need to maintain the financial equilibrium of the social security system based on solidarity justified the restriction. Companies could still take out additional insurance with private insurers. That the affiliation was mandatory was necessary because of the risk of leaving the insurance association with 'bad' risks only (paras 85-91).

Commission v. Austria (patent lawyers), 2009 addressed two requirements Austrian law imposed on patent lawyers established abroad when they provided services in Austria, namely that they had to have a civil liability insurance which need not have been taken out necessarily in Austria but had to cover a minimum insurance sum; and that they needed to appoint an agent in Austria for the communication with authorities and courts. The first requirement was, according to the Court, a restriction of the freedom of services, because foreign patent lawyers had to take out an insurance policy which was not necessarily required in their 'home' state (paras 27-9). However, the protection of service recipients justified that restriction, in particular because it was not an alternative to inform the recipient that the lawyer he consulted did not have insurance, given the risk that recipients failed to comprehend the implications of that information (paras 32-37). In contrast, the second requirement was not justified. The requirements of regular procedure could be met through the use of postal services, as expressly acknowledged by Community regulation, or electronic means (paras 47-53). In a similar vein, in Commission v. Austria (bank account), 2009 Austrian law in 
combination with the regulation issued by a professional association required self-employed doctors established in the Land Vorarlberg to have a bank account with a specific regional bank in Austria. This account was meant to simplify the administration of credits and reimbursements received from sickness funds and to secure possible claims. The Court examined the free movement of services, as the services of banks came within the scope of that freedom. The Court reiterated that not just regulation by the state was covered by the freedom of services, but also collective private regulation (paras 32-37). Austria's requirement restricted doctors in Austria in accepting services from foreign banks and those banks in providing them (paras 40-1). The simplification of administrative procedures was not a ground suitable to justify a restriction of the freedom of services. As to the prevention of abuse or the need to secure claims, less restrictive alternatives existed, like the exchange of information between the entities involved and the authorization for a bank to debit an account directly (paras 46-49).

\section{Services more broadly}

In the interest of completeness, a few more services cases need to be mentioned. In Commission v. France (insurance), 2000 the Court invalidated based on the third non-life insurance and the third life assurance Directives 92/49 and 92/96 France's requirement to notify systematically some conditions of insurance contracts offered in France. In Commission v. Belgium (insurance), 2000 the Court again interpreted Directive 92/49, holding that it applied to insurance offered by undertakings at their own risk even when that insurance was part of a statutory social security scheme. In $A B B O I, 2000$ the Court clarified the framework for insurance undertakings under the third non-life insurance Directive for the setting up of undertakings pursuing business other than insurance. In Kvaerner, 2001 the Court clarified the power to tax insurance premiums under the Second non-life insurance Directive 88/357 when a parent company had concluded insurance contracts for the benefit of subsidiaries in other member states. In Axa Royale, 2002 the Court held that Belgium could not, under the third life assurance Directive 92/96, require companies to include in proposals and policies a general and vague warning as to the disadvantages of cancelling, surrendering or reducing a life-assurance contract. Testa and Lazzeri, 2002 clarified the term 'management of investment portfolios' in the context of Directive 93/22 on investment services in the securities field and the latitude the Directive left to the member states.

The case Der Weduwe, 2002 was rejected by the Court as inadmissible. The situation related to the freedom of services and seemingly raised a puzzling question: How was a service provider whom Luxembourg law obliged, under the threat of criminal penalties, not to disclose information owing to the banking secrecy to behave when Belgian law obliged him, under the threat of criminal penalties, to disclose that very same information in criminal proceedings? According to the Court the question was hypothetical though, since it was based on 
an unsound interpretation of Luxembourg law. That law equally seemed to allow such persons to disclose the information in criminal procedures (para. 37).

In Commission v. Italy (direct insurance), 2003 the Court again applied the third non-life insurance directive 92/49, this time, firstly, striking down certain measures Italy took to freeze specific insurance rates, because those measures failed to live up to the freedom to set premiums contained in the directive and, notably, failed to come within the exception of general price-control systems. Secondly, the Court validated Italy's gathering of certain data to combat insurance fraud. In contrast, both in Commission v. Luxembourg (insurance rates), 2004 and in Commission v. France (insurance rates), 2004 the Court found a compulsory bonus-malus system for contracts insuring third-party liability arising out of motor vehicle accidents to be compatible with the third non-life insurance directive, because the system did not fix the premiums.

In Asempre, 2004 the Court clarified the scope of the services that could be reserved to a national universal postal service provider under Directive 97/67 on postal services, in particular with regard to self-provision and money order services. In Paul, 2004 the Court applied the Community banking legislation, namely Directives $94 / 19,77 / 780,89 / 299$, and $89 / 646$, to the effect that a depositor did not have a right against the competent authority to have certain supervisory measures taken, if the minimum deposit amount was guaranteed. Moreover, the relevant directives or state liability did not confer a depositor rights, bar the guarantee of the minimum deposit, in case his deposit was unavailable as a consequence of defective supervision.

In Commission v. Belgium, 2005 the Court rejected the case, because the Commission had failed to prove that Belgium's legislation governing transparency to protect the consumer in certain customer loyalty programmes, which (the legislation) in itself was not contrary to the freedom of services, was implemented by an administrative practice which on its own breached the free movement of services. In Ostermann, 2005, the Court explained how the setting of a reasonable period for payment chimed with article 4(6) fourth motor insurance Directive 2000/26. In Commission v. Spain (direct insurance), 2007 the Court rejected the Commission's allegation that Spain's regime governing cancellation of insurance contracts in case of cessions of bundles of contracts had violated Directive 92/49 and 2002/83 on non-life insurance and life assurance, respectively.

In International Mail, 2007 the Court came back to postal services under Directive $97 / 67$ as well as Directive 2002/39, which had taken liberalization a step further, to clarify when certain cross-border postal services could lawfully be reserved to a universal postal service provider. In particular the Court elaborated that the financial balance of such a provider had to be at risk to allow reservation of those services and that mere expediency was not sufficient to justify a monopoly in cross-border mail services. In Deutsche Post, 2008 the Court essentially ruled that the universal service provider under Directive 97/67, which opened part of the postal distribution chain to some business customers and 
granted them preferential tariffs, had to offer the same tariffs to all customers willing to provide similar bulk mail at the same point in the distribution chain.

Finally, the Court in Opinion on GATS amendments, 2009 addressed the modifications to the GATS that had become necessary because new member states had joined the Community. The Court opined that the competence to modify the GATS commitments was still shared between the Community and the member states despite the amendments the Treaty of Nice had made to the common commercial policy. Article 133(6) Treaty declared the competence to be shared with regard to certain sensitive policy fields. Moreover, the act of the Community approving the amendments to the GATS had to be based both on the common commercial policy and the common transport policy.

\section{The 2010s}

Not quite half of the decade is over and it is already clear that the case-law of the Court continues to grow - perhaps not exponentially, but certainly steadily on a very high level. The free movement of workers and citizens has already yielded more than 60 decisions and social security some 30 decisions, while the free movement of services and establishment have contributed the bulk, with more than 120 decisions.

\section{Workers and citizens}

\section{Advantages}

The Court developed its case-law on advantages migrant workers enjoyed in the first years of the 2010s. Commission v. Netherlands (portable funding), 2012 dealt with a requirement the Netherlands imposed when support for studies abroad was applied for. According to Dutch law, funding to study at a university outside the Netherlands, so-called portable funding, was only granted when a prospective student had resided in the Netherlands during three out of the six years preceding enrolment at the foreign university, pursuant to the so-called 3 out 6 years rule. The Commission took issue with the 3 out 6 years rule, but only with regard to article 7(2) Regulation $1612 / 68$, i. e. for workers and their children. The Court sided with the Commission and found free movement of workers and article 7(2) violated. The residence requirement amounted to indirect discrimination, as the majority of those migrant workers, viz. their children, and frontier workers residing abroad were nationals of other member states (paras 39 and 55). The comparability of situations required to find unequal treatment was given between, on the one hand, workers residing in the Netherlands and, on the other, frontier workers or migrant workers falling short of three years of residence (paras 42-44). Such comparability required objective and easily identi- 